University of Zurich

Department of Economics

Working Paper Series

ISSN 1664-7041 (print)

ISSN 1664-705X (online)

Working Paper No. 115

Similarity of Income Distributions and the Extensive and Intensive Margin of Bilateral Trade Flows

Claudia Bernasconi

February 2013 


\title{
Similarity of Income Distributions and the Extensive and Intensive Margin of Bilateral Trade Flows*
}

\author{
Claudia Bernasconi, University of Zurich ${ }^{\dagger}$
}

27th February 2013

\begin{abstract}
This paper investigates empirically how similarity of demand structures - approximated by similarity of income distributions - affects trade patterns along both the extensive and intensive margin. The idea that similarity of demand structures intensifies trade goes back to the well-known Linder hypothesis. Based on a sample of 102 countries, I find that bilateral trade volumes are increasing in the overlap of two countries income distributions. This effect is driven by both the extensive and intensive margin. I establish two novel measures of income similarity - the average income level of the overlap area and the range of incomes for which two distributions overlap - and document that both are important determinants of bilateral trade margins. My analysis shows that the positive relationship between similarity of income distributions and bilateral trade margins is present at the aggregate and disaggregate level of trade flows.
\end{abstract}

JEL classification: F10, D31, F14

Keywords: similarity of income distributions, Linder hypothesis, nonhomothetic preferences, extensive and intensive margin of trade, gravity equation

\footnotetext{
${ }^{*}$ I thank Reto Foellmi, Christian Hepenstrick, Andreas Kohler, James Markusen, Marc Melitz, Josef Zweimüller and seminar participants at University of Zurich and Basel for helpful comments and discussions. I gratefully acknowledge financial support by the Forschungskredit der Universität Zürich and the Swiss National Science Foundation.

${ }^{\dagger}$ University of Zurich, Department of Economics, Muehlebachstrasse 86, CH-8008 Zurich, e-mail: claudia.bernasconi@econ.uzh.ch
} 


\section{Introduction}

The gravity equation identified many determinants of trade flows, such as distance and economic sizes. Recently, a growing literature focused on the role of demand side forces for the patterns of trade, such as per capita income and within-country income distribution. This paper extends this literature by showing that not only the distribution of income per se matters but that bilateral trade flows are also determined by the extent to which two income distributions are similar.

This paper investigates empirically how similarity of demand structures - approximated by similarity of income distributions - affects trade patterns along the extensive and intensive margin. The idea that similarity of demand structures intensifies trade has a long tradition in the economic literature, going back to the well-known Linder hypothesis. According to Linder (1961) countries produce those goods for which domestic demand is large as proximity to demand serves as a comparative advantage. He argued that this congruence of consumption and production patterns intensifies trade among countries with similar demand structures.

Contrasting Japan's imports from Canada to Japan's imports from Mexico illustrates the type of comparison on which the empirical analysis is based ${ }^{1}$ In 2002, Japan imports consumer goods from Canada worth 1.2 billion US $\$$ and from Mexico for less than half as much. At the same time, Japan has a larger overlap with Canada's than with Mexico's income distribution. The overlap, the main measure of similarity, is the minimum integral of two income distributions. Hence, Japan imports more from the source country which is more similar. Moreover, the higher import value from Canada is driven by both margins. While Japan's imports from Canada are composed of 671 different products (HS 6-digit codes) its imports from Mexico consist of 377 categories. Thus, Japan imports a larger diversity of goods - the extensive margin - from the exporter which has a more similar income distribution. On average, in a given product category Japan imports goods from Canada for 1.8 million US $\$$ and from Mexico for 1.4 million US\$. Hence, also Japan's intensive margin of imports is higher from the source country with the more resembling income distribution.

This paper makes two major contributions. First, this is, to the best of my knowledge, the first study which decomposes the effect of income similarity on trade flows into effects at the extensive and intensive margin. Second, this paper is among the very first which approximate similarity of demand patterns with similarity of income distributions - as opposed to similarity of average incomes - in order to relate it to bilateral trade. ${ }^{2}$ Furthermore, I make two methodological contributions. On the one hand, beyond using the overlap (minimum integral) of two income distributions to quantify similarity, I establish two novel measures which characterize the overlap area - the average income level and the width of the overlap. On the other hand, I develop a new way of computing national

\footnotetext{
${ }^{1}$ In 2002, Canada and Mexico have approximately the same GDP and are equally far away from Japan.

${ }^{2}$ Searching for the keywords "income distribution" \& "similarity" \& "trade" on EconLit, for example, does not give one single reference to such a study. Two related working papers, which are not in EconLit, are discussed below.
} 
income distributions with data on decile and quintile income shares and per capita income. The simple procedure imposes no parametric assumptions about the functional form of the distributions.

The three main findings of this paper provide comprehensive and consistent evidence that similarity of demand structures is an important determinant of bilateral trade margins. First, the more similar two countries are regarding their income distributions, the higher is their aggregate bilateral trade volume in consumer goods. The effect of similarity on trade volumes is driven by both the extensive and intensive margin. The magnitudes of the effects are economically relevant. On average, countries with a one standard deviation higher overlap have a $35 \%$ higher trade value, trade a $22 \%$ more diversified bundle of goods (extensive margin) and trade 13\% more within a given set of goods (intensive margin). Hence, the patterns of the Japan-Canada versus Japan-Mexico example above are systematic for a sample of 102 countries. My augmented gravity equation conditions on importer and exporter fixed effects as well as trade costs in order to isolate the effect of similarity from many supply side effects, such as technology, and from gravity forces, such as trade costs and economic sizes. Moreover, I find no effect of income similarity on trade in industries containing mostly unprocessed goods, and the effect is largest in industries including highly differentiated products, such as chemicals or machinery and transport equipment. The first set of results is very robust, noteworthy to accounting for zeros in trade data and controlling for similarity of average incomes.

Second, the two novel measures characterizing the overlap area - the average income level and the width of the overlap - are also positively related to the extensive and intensive margin of trade. The average income level of the overlap area serves as an additional explanatory variable as it describes the location of the overlap, whereas the width of the overlap is an alternative measure for income similarity as it reflects how broad the range of incomes is for which two distributions overlap. I find that not only the extent to which two income distributions overlap but also at which income levels the overlap is concentrated matters for trade. Moreover, measuring income similarity with the width of the overlap implies too that bilateral trade margins increase in similarity of demand patterns.

Third, also both margins of disaggregate bilateral trade flows increase in similarity of income distributions. I document that both the probability that two countries trade a given product (extensive margin) and the trade value within a given category (intensive margin) increase in similarity of income distributions. Moreover, both margins increase in the overlap as well as in the average income level and the width of the overlap. Disaggregate trade flows are observed at the six digit level of the Harmonized System (HS). The numerous zeros are taken into account by applying a simplified version of the semiparametric selection model of Cosslett (1991). The findings on the disaggregate level are robust, notably if the analysis is performed on the HS 4, 2, 1-digit level and if it is controlled for similarity of average incomes. Thus, the findings on aggregate trade margins are reinforced by the results on disaggregate trade flows. This differs from Hallak (2010) who finds that due to an aggregation bias 
the Linder hypothesis can be supported at the sectoral but not at the aggregate level.

This paper tests the hypothesis that bilateral trade flows increase along both margins in similarity of demand structures. There are three points to be highlighted about this hypothesis. (i) If individuals have nonhomothetic preferences the income level reflects the demand pattern of a consumer. There is considerable evidence that both expenditure shares and the set of goods an individual consumes

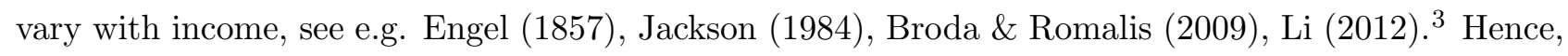
a country's income distribution reflects its demand pattern and similarity of income distributions approximates similarity of demand structures. (ii) The home bias, i.e. a country produces those goods for which domestic demand is relatively large, can be due to imperfect information of producers - local producers have a better knowledge of domestic than foreign needs, see Linder (1961) - implying that proximity to demand serves as a comparative advantage or due to the standard home market effect in Krugman (1980) which results from increasing returns to scale and trade costs.4 This congruence of consumption and production patterns implies that countries with similar demand structures produce similar goods. (iii) Trade emerges because of product differentiation and love for variety.

The combination of (i), (ii) and (iii) implies that the more similar the demand structures of two countries are, the more similar goods they produce and due to product differentiation such country pairs have a larger scope for trade. Moreover, as demand patterns become more similar this can imply that a broader range of goods is purchased in the other country (extensive margin) or that demand for a certain product sold in the other country increases (intensive margin). In sum, similarity of demand structures - approximated by similarity of income distributions - raises bilateral trade volumes along both the extensive and intensive margin.

Note that "solely" considering (i) implies that a country's income distribution affects its imports, see e.g. Dalgin et al. (2008). In order to predict that the degree to which two income distributions are similar affects the respective bilateral trade flow the combination of (i), (ii) and (iii) is needed.

This paper is mainly related to four strands in the literature on international trade. First, there are a handful of theories predicting a positive association between income similarity and trade. By imposing that manufactured goods have a high income elasticity of demand in consumption and are at the same time relatively capital intensive in production the seminal article by Markusen (1986) predicts large trade volumes among capital abundant industrialized countries with similar demand elasticities in manufactured goods. Foellmi et al. (2010) build a theoretical framework for the extensive margin. Their model predicts that countries trade a larger set of goods the more similar they are regarding their per capita endowments $6^{6}$ The theory in Auer (2010) provides a formal derivation

\footnotetext{
${ }^{3}$ That the income elasticity of demand varies across goods is shown, among others, in Hunter \& Markusen (1988), Hunter (1991), Bils \& Klenow (1998), Deaton (1975) and Dalgin et al. (2008).

${ }^{4} \mathrm{~A}$ home bias in consumption can, for example, also be established through an assumption linking endowments or technology and income elasticity of demand, see Markusen (2010, 1986), Murphy \& Shleifer (1997) or Fieler (2011a).

${ }^{5}$ This assumption is empirically supported in Caron et al. $(2012)$.

6 Kohler (2012) extends this model to a dynamic setting and analyzes the interactions of trade and growth.
} 
of the Linder hypothesis as it predicts higher trade flows among countries with more similar taste distributions. Murphy \& Shleifer (1997), Hallak (2010) and Fajgelbaum et al. (2011b) hypothesize that countries with more similar levels of per capita incomes trade more with each other as such country pairs demand and produce goods of similar quality. Fajgelbaum et al. (2011a) show that not only trade flows but also foreign direct investment is intensive between similar countries. Second, a number of studies empirically analyze the relationship between income similarity and bilateral trade. The results are mixed for studies measuring income similarity with similarity of average incomes, see e.g. Hallak (2010), Choi (2002), McPherson et al. (2000) or Thursby \& Thursby (1987). To my knowledge, there are only two working papers which analyze the relation between similarity of income distributions and bilateral trade flows, Martinez-Zarzoso \& Vollmer (2010) and Bohman \& Nilsson (2007).77 Both studies provide evidence for a positive relationship. The present paper, however, goes beyond these studies. I provide a thorough analysis that disentangles the effect of income similarity on trade values into an effect on the extensive and intensive margin, for both aggregate as well as disaggregate trade flows. Moreover, my analysis is especially careful along several dimensions, such as computation of income distributions, identification strategy and the type of goods which are considered (consumer goods). Third, how the within-country income distribution shapes trade patterns is, among others, discussed in Mitra \& Trindade (2005), Dalgin et al. (2008), Matsuyama (2000), Francois \& Kaplan (1996), Fajgelbaum et al. (2011b) and Fieler (2011b) 8 Finally, the theories with heterogeneous firms and fixed exporting costs, starting with Melitz (2003), have contributed considerably to the initiation of a literature distinguishing trade along the extensive versus intensive margin.

The paper is organized as follows. Section 2 documents how similarity of income distributions is measured and how national income distributions are computed. Trade margins are defined in section 3 . Section 4 specifies the empirical model. The results are discussed in section 5 and section 6 concludes.

\section{Similarity of Income Distributions}

In order to approximate the degree to which the demand structure of country $c$ resembles the demand structure of country $n$ I construct a similarity measure of the income distributions of country $c$ and $n$. First, the similarity measures are described conceptually (section 2.1), with a slight abuse of notation. Thereafter it is outlined how the conceptual measures are operationalized with the data. In section 2.2 I document how I compute a discrete income distribution with decile respectively quintile income shares and GDP per capita for each country. Finally, how the similarity measures of two discrete empirical income distributions are calculated is described in section 2.3 .

\footnotetext{
7Choi et al. (2009) also study similarity of income distributions, however in another context. They analyze how similarity of income distributions and similarity of import price distributions of two multilateral importers are related.

${ }^{8}$ How per capita income affects trade flows is studied, among others, in Markusen (2010), Fieler (2011a), Simonovska (2010), Sauré (2009), Hepenstrick (2010), Bernasconi \& Wuergler (2012).
} 


\subsection{Definition of Similarity Measures}

Let $f_{a}(x)$ denote the density function of income $x$ of country $a \in\{c, n\}$, where $0 \leq x<\infty .9$ The overlap $O_{n c}$, the main measure of similarity, is defined as the minimum integral of the income distributions of two countries $c$ and $n$.

$$
O_{n c}=\int_{0}^{\infty} \min \left\{f_{c}(x), f_{n}(x)\right\} d x, \quad \in[0,1]
$$

Figure 1 depicts the income distributions of country $c$ and $n$. The gray shaded area represents the overlap of the two income distributions. The overlap has the following properties. It is bounded between 0 and 1 . It is 0 if two income distributions do not overlap at all, i.e. if the minimum income of $c$ is larger than the maximum income of $n$. The overlap is maximized for two countries with identical income distributions $\left(O_{n c}=\int_{0}^{\infty} f_{a}(x) d x=1, a \in\{c, n\}\right)$. The overlap is symmetric, i.e. $O_{n c}=O_{c n}$.

Figure 1: Illustration of the Overlap of two Income Distributions, $O_{n c}$

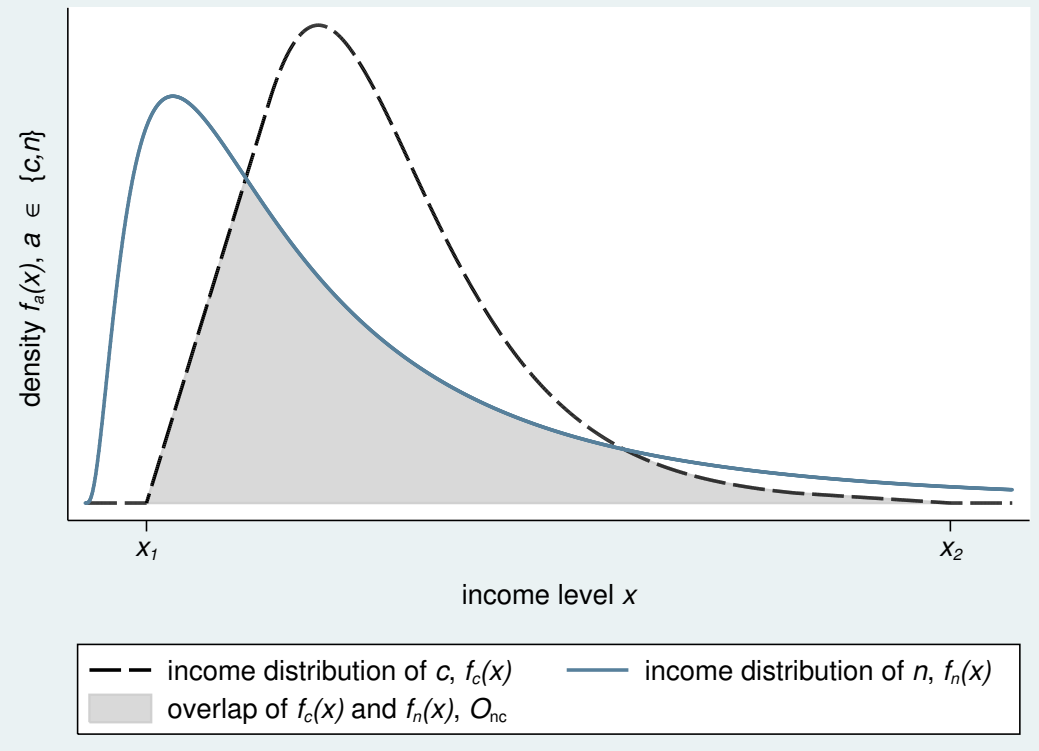

I establish an additional measure which characterizes the overlap area. It represents at which income levels the overlap accrues. $O_{n c}^{\bar{x}}$ is defined as the average income level of the overlap area.

$$
\begin{aligned}
O_{n c}^{\bar{x}} & =\int_{0}^{\infty}\left[\frac{\min \left\{f_{c}(x), f_{n}(x)\right\}}{O_{n c}} \cdot x\right] d x, \quad \in\left(0, \min \left\{x_{c}^{\max }, x_{n}^{\max }\right\}\right) \\
1 & =\int_{0}^{\infty} \frac{\min \left\{f_{c}(x), f_{n}(x)\right\}}{O_{n c}} d x
\end{aligned}
$$

$x_{a}^{\max }$ is the maximum income level of $a$. The size of the overlap area has no impact on $O_{n c}^{\bar{x}}$ as it is rescaled to 1 in order to calculate the average income level. Only the relative concentration of

\footnotetext{
${ }^{9}$ It is assumed that $f_{a}(x)$ has no "gaps" in the sense that there exists no $\epsilon>0$ such that $\int_{\ddot{x}-\epsilon}^{\ddot{x}+\epsilon} f_{a}(x) d x=0$ and $\int_{\dot{x}-\epsilon}^{\dot{x}+\epsilon} f_{a}(x) d x>0$ and $\int_{\dddot{x}}^{\dddot{x}+\epsilon} f_{a}(x) d x>0$, where $\dot{x}+\epsilon<\ddot{x}-\epsilon<\ddot{x}+\epsilon<\dddot{x}-\epsilon$ and $\dot{x}<\ddot{x}<\dddot{x}$, for any positive and finite $\dot{x}, \ddot{x}$ and $\dddot{x}$. All empirical income distributions fulfill this assumption by construction.
} 
the overlap area along the income axis matters for $O_{n c}^{\bar{x}}$. For two countries with identical income distributions $O_{n c}^{\bar{x}}$ is equal to the average income $\bar{x}_{a}=\int_{0}^{\infty} f(x)_{a} x d x, a \in\{c, n\} . O_{n c}^{\bar{x}}$ varies among country pairs with identical income distributions as the overlap may occur at different income levels. In contrast, for such country pairs there is no variation in the overlap $O_{n c}$ as the latter equals 1 whenever the two distributions are identical.

The alternative measure of similarity represents the width of the overlap area. In figure 1 the income distributions of country $c$ and $n$ overlap for income levels between $x_{1}$ and $x_{2}$. The width of the overlap area $O_{n c}^{w}$ is defined as the distance between these two income levels.

$$
\begin{gathered}
O_{n c}^{w}=x_{2}-x_{1}, \quad \in\left(0, \min \left\{x_{c}^{\max }, x_{n}^{\max }\right\}\right] \\
x_{1} \geq 0, \quad x_{2}>x_{1}, \quad x_{1} \text { and } x_{2} \text { are such that } \\
\min \left\{f_{c}(x), f_{n}(x)\right\}=\left\{\begin{aligned}
0 & \text { for } x<x_{1} \text { and } x>x_{2} \\
>0 & \text { for } x_{1} \leq x \leq x_{2}
\end{aligned}\right.
\end{gathered}
$$

$O_{n c}^{w}$ is 0 if two income distributions do not overlap at all 10 For two countries with identical income distributions $O_{n c}^{w}$ is equal to the difference between the maximum and minimum income level.

The overlap has been used as a measure of similarity of income distributions in the literature before, see Choi et al. (2009), Bohman \& Nilsson (2007) or Martinez-Zarzoso \& Vollmer (2010). In this paper two further similarity measures are proposed, $O_{n c}^{\bar{x}}$ and $O_{n c}^{w}$.

\subsection{Computation of Income Distributions}

I use income shares of deciles and quintiles reported in the World Income Inequality Database (WIID2c), UNU-WIDER (2008b), and GDP per capita from Heston et al. (2009) to compute a discrete empirical income distribution for each country and year. $s_{a}^{d}\left(s_{a}^{q}\right)$ denotes the share of total income in country $a$ which is earned by decile $d$ (quintile $q$ ), where $d \in\{1, \ldots, 10\}$ and $q \in\{1, \ldots, 5\}$. As inequality changes slowly over time I choose for each country the observation with the highest data quality within a certain time span - for example between 1992 and 2002 - and use this observation for the whole period, see the data appendix for details.

The first step of the transformation of the inequality data $\left(s_{a}^{d}, s_{a}^{q}\right)$ into income distributions is the assignment of an average income level to each decile respectively quintile.

$$
x_{a t}^{d}=\frac{s_{a}^{d} \cdot G D P_{a t}}{P O P_{a t} / 10}, \quad x_{a t}^{q}=\frac{s_{a}^{q} \cdot G D P_{a t}}{P O P_{a t} / 5}
$$

The numerator of the first expression equals total income earned by decile $d$ and the denominator amounts to the number of individuals belonging to decile $d$. Thus, $x_{a t}^{d}$ is the average income of an

\footnotetext{
${ }^{10}$ For simplicity, the condition pinning down the thresholds $x_{1}$ and $x_{2}$ is formulated such that $O_{n c}^{w}$ is strictly positive.
} 
individual belonging to decile $d$ in country $a$ and year $t$. Total income is approximated by real PPP GDP (in I $\$$ and 2005 constant prices), denoted by $G D P_{a t}$. POPat indicates the population.

As each $x_{a t}^{d}$ represents a $10^{t h}$ of the population it has the area of 0.1 in the probability mass function of the discrete empirical income distribution. In the second step of the transformation of the inequality data into income distributions the area of 0.1 of each $x_{a t}^{d}$-which is collapsed at the value of the average income of decile $d$ - is redistributed on an income interval. Thereby I make only few assumptions, and importantly no parametric assumption about the functional form of the income distribution. The assumptions are, (i) the area of 0.1 of $x_{a t}^{d}$ is redistributed on the interval $\left[\underline{\underline{x}}_{a t}^{d}, \overline{\bar{x}}_{a t}^{d}\right]$,

$$
\underline{x}_{a t}^{d}=\left\{\begin{array}{ll}
x_{a t}^{d}-\left(x_{a t}^{d}-x_{a t}^{d-1}\right) / 2 & \text { if } d>1 \\
x_{a t}^{\min } & \text { if } d=1
\end{array}, \quad \overline{\bar{x}}_{a t}^{d}= \begin{cases}x_{a t}^{d}+\left(x_{a t}^{d+1}-x_{a t}^{d}\right) / 2 & \text { if } d<10 \\
x_{a t}^{\max } & \text { if } d=10\end{cases}\right.
$$

(ii) the redistribution described in assumption (i) occurs uniformly over the income interval $\underline{\underline{x}}_{a t}^{d}, \overline{\bar{x}}_{a t}^{d} .11$, (iii) $x_{a t}^{\min }=1 \forall a, \forall t$, (iv) $x_{a t}^{\max }=x_{a t}^{10}+2.7\left(x_{a t}^{10}-x_{a t}^{9}\right)$. I estimated the relationship in assumption (iv) using the Luxembourg Income Study (LIS) which contains individual data on income for a small number of countries 1213

In order to facilitate the calculation of similarity measures of two discrete income distributions, the densities are partitioned into common intervals with a length of 5'000, where income goes from 1 to 150 '000 (in I $\$$ and 2005 constant prices), for all countries. After this final step a discrete empirical income distribution has been computed for each country $a$ and year $t$. Figure 2 shows as an example Canada's income distribution for 2002, see figure A1 for further countries. The discrete income distributions have a slightly different notation. $\breve{x}$ denotes the income interval, $\breve{x} \in$ $\left\{\left[1-5^{\prime} 000\right], \ldots,\left[145^{\prime} 001-150^{\prime} 000\right]\right\} . f_{a}(\breve{x})$ is the density of country a's income distribution which accrues at income interval $\breve{x}$. For instance, $f_{C A N}\left(\left[1-5^{\prime} 000\right]\right)=0.04$ 14 By definition the densities sum to $1, \sum_{\breve{x}} f_{a}(\breve{x})=1$, i.e. the area below the line in figure 2 is equal to 1 .

Although income shares $\left(s_{a}^{d}, s_{a}^{q}\right)$ are constant within a time span average income levels of deciles respectively quintiles $\left(x_{a t}^{d}, x_{a t}^{q}\right)$, and hence income distributions, change yearly. However, as will be outlined in section 4 , the effect of similarity on trade is identified with variation across exporters and variation across importers. Hence, I do not rely on variation of the similarity measures over time.

In figure A2 it is shown for Canada that the income distribution computed with WIID - which only has information for deciles - is not too different from the income distribution computed with LIS - which has information for each percentile.

\footnotetext{
${ }^{11}$ The uniform redistribution is a parametric assumption about the functional form of the income distribution within deciles. There is no parametric assumption about the functional form of the entire income distribution, i.e. across deciles.

${ }^{12}$ I approximate $x_{a t}^{\max }$ by the $100 t h$ percentile and find that on average $\left(x_{a t}^{\max }-x_{a t}^{10}\right) /\left(x_{a t}^{10}-x_{a t}^{9}\right)$ is equal to 2.7 .

${ }^{13}$ For quintiles, the area of 0.2 of each $x_{a t}^{q}$ is redistributed analogously on $\left[\underline{x}_{a t}^{q}, \overline{\bar{x}}_{a t}^{q}\right]$. (iv) is $x_{a t}^{\text {max }}=x_{a t}^{5}+3.8\left(x_{a t}^{5}-x_{a t}^{4}\right)$.

${ }^{14}$ In the graphs, the width of the intervals is 1 such that the area below the line of an interval $\breve{x}$ is equal to $f_{a}(\breve{x})$.
} 
Figure 2: A Discrete Empirical Income Distribution for Canada

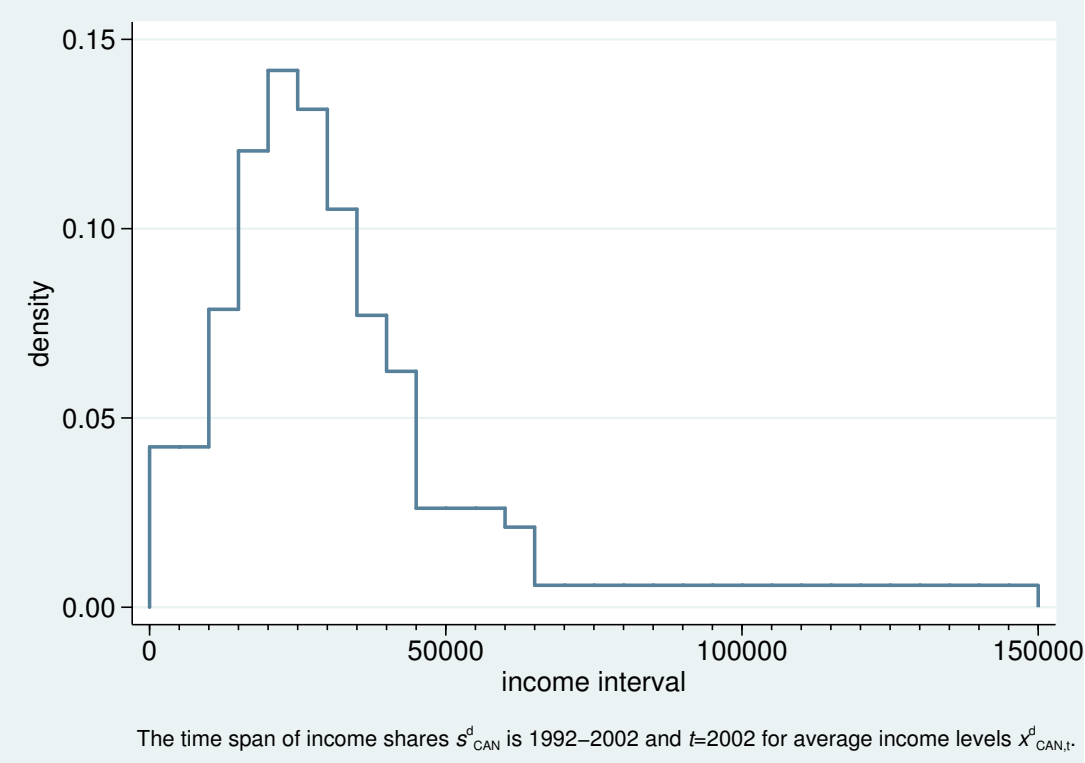

\subsection{Calculation of Similarity Measures}

Equation (1), which is based on continuous income distributions, is adapted such that it yields the overlap of two discrete income distributions 15

$$
O_{n c}=\sum_{\breve{x}} \min \left\{f_{c}(\breve{x}), f_{n}(\breve{x})\right\}, \quad \in[0,1]
$$

Figure 3 illustrates how the overlap for Japan and Canada is measured empirically. The additional measure taking into account at which income levels the overlap is concentrated and the alternative measure representing the width of the overlap area are calculated as follows with discrete income distributions.

$$
\begin{aligned}
O_{n c}^{\bar{x}} & =\sum_{\breve{x}}\left[\frac{\min \left\{f_{c}(\breve{x}), f_{n}(\breve{x})\right\}}{O_{n c}} \cdot \breve{x}(\breve{x})\right], \in\left[2^{\prime} 500,147^{\prime} 500\right], \sum_{\breve{x}} \frac{\min \left\{f_{c}(\breve{x}), f_{n}(\breve{x})\right\}}{O_{n c}}=1 \\
O_{n c}^{w} & =\sum_{\breve{x}} 1\left(\min \left\{f_{c}(\breve{x}), f_{n}(\breve{x})\right\}>0\right) \cdot 5^{\prime} 000, \in\left[5^{\prime} 000,150^{\prime} 000\right]
\end{aligned}
$$

$\breve{x}(\breve{x})$ designates the middle income level of income interval $\breve{x}, \breve{x} \in\left\{2^{\prime} 500, \ldots, 147^{\prime} 500\right\}$.

For illustration, table 1 lists all three measures for the country pairs Japan-Canada and JapanMexico. As the income distributions of Japan and Canada are very alike (see figure 3) the overlap is as high as 0.83. In contrast, incomes in Mexico are much more concentrated at low income levels, which leads to an overlap with Japan of only 0.36, see figure A3. In the whole sample, the overlap effectively goes from almost 0 to 1 , with mean 0.49 and standard deviation 0.29 (see figure A4 and

\footnotetext{
${ }^{15}$ I could use a Kernel smoothing procedure in order to transform the discrete income distributions into continuous income distributions, however, I believe that this would suggest an exaggerated precision for income distributions which are based on 10 , or even 5 , data points $\left(x_{a t}^{1}, \ldots, x_{a t}^{10}\right)$, respectively $\left(x_{a t}^{1}, \ldots, x_{a t}^{5}\right)$.
} 
Figure 3: Illustration of the Overlap of two Discrete Empirical Income Distributions, $O_{n c}$

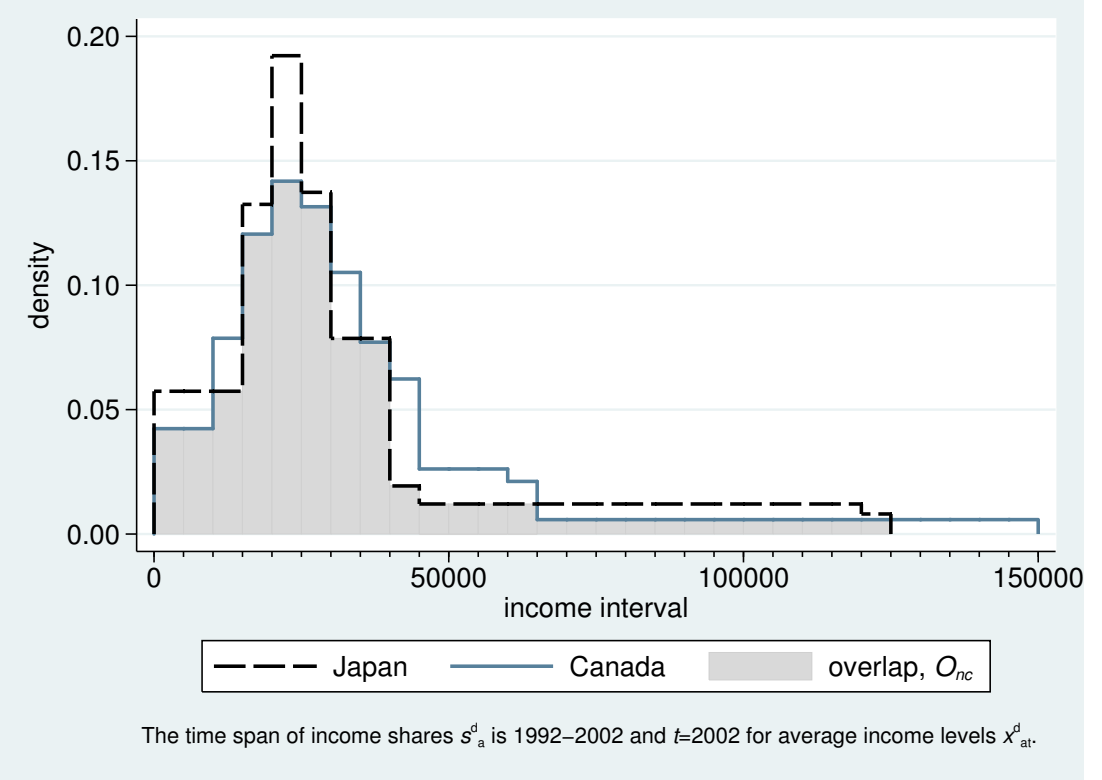

table A2). Japan's and Canada's income distributions overlap for a wide range of income levels, $O_{C A N, J P N}^{w}=125^{\prime} 000$. As incomes in Mexico are rather dispersed also the overlap of Japan and Mexico accrues over a wide range of incomes, namely from 1 up to 115'000. Thus, while the overlap of JapanCanada is more than twice as large than the overlap of Japan-Mexico, the overlap region of these two country pairs occurs at a similar income range. In addition, the relative concentration of the overlap area is not too different such that the average income of the overlap area for Japan-Canada is only slightly higher than for Japan-Mexico. In the entire sample, the average income level of the overlap area $O_{n c}^{\bar{x}}$ ranges from 2'500 up to $45^{\prime} 000$. The mean is 12'300 and the standard deviation 9'100. The width of the overlap area $O_{n c}^{w}$ covers the entire range of values from 5'000 to 150'000, with mean 48'700 and standard deviation 36'300. Remember that all similarity measures are symmetric.

Table 1: Illustrating the Similarity Measures with an Example

\begin{tabular}{r|rrr}
\hline & & CAN & MEX \\
JPN & & & \\
& $O_{n c}$ & 0.829 & 0.363 \\
& $O_{n c}^{\bar{x}}$ & $30^{\prime} 875$ & $28^{\prime} 649$ \\
& $O_{n c}^{w}$ & $125^{\prime} 000$ & $115^{\prime} 000$ \\
\hline \multicolumn{3}{c}{ year $=2002$}
\end{tabular}

Note the following difference between the overlap $O_{n c}$ and the average income level of the overlap area $O_{n c}^{\bar{x}}$. While the overlap is typically large for North-North and South-South country pairs the average income level of the overlap area is much higher for North-North country pairs than for SouthSouth country pairs, see table A4. For illustration, the overlap for Japan-Canada as well as for Somalia-Guinea is around 0.83. In contrast, the average income level of the overlap area of Japan and 
Canada is 30'900 while it amounts to less than a tenth for Somalia and Guinea (2'500). The same discrepancy is present between the overlap $O_{n c}$ and the width of the overlap area $O_{n c}^{w}$. For instance, Somalia-Guinea overlap only over a small income range (5’000) and Japan-Canada almost over the entire range of incomes (125’000). Consequently, the correlation between the overlap and the two alternative measures is low, whereas the two alternative measures are highly correlated ${ }^{16}$

Most previous studies approximate similarity of demand patterns with similarity of average income levels. However, using the average income as a first order approximation of the income distribution neglects important information. About one third of the variation in the overlap cannot be explained by the variation in the GDP per capita ratio. There is substantial variation in similarity of income distributions for a given similarity in average income levels. The overlap ranges, for example, from 0.28 up to 0.97 for a GDP per capita ratio of 0.50 , see gray bar in figure 4 . In the same figure it is illustrated that similarity in average incomes approximates similarity in income distributions much better for North-North and North-South country pairs than for South-South country pairs.

Figure 4: Similarity of Income Distributions versus Similarity of Average Incomes

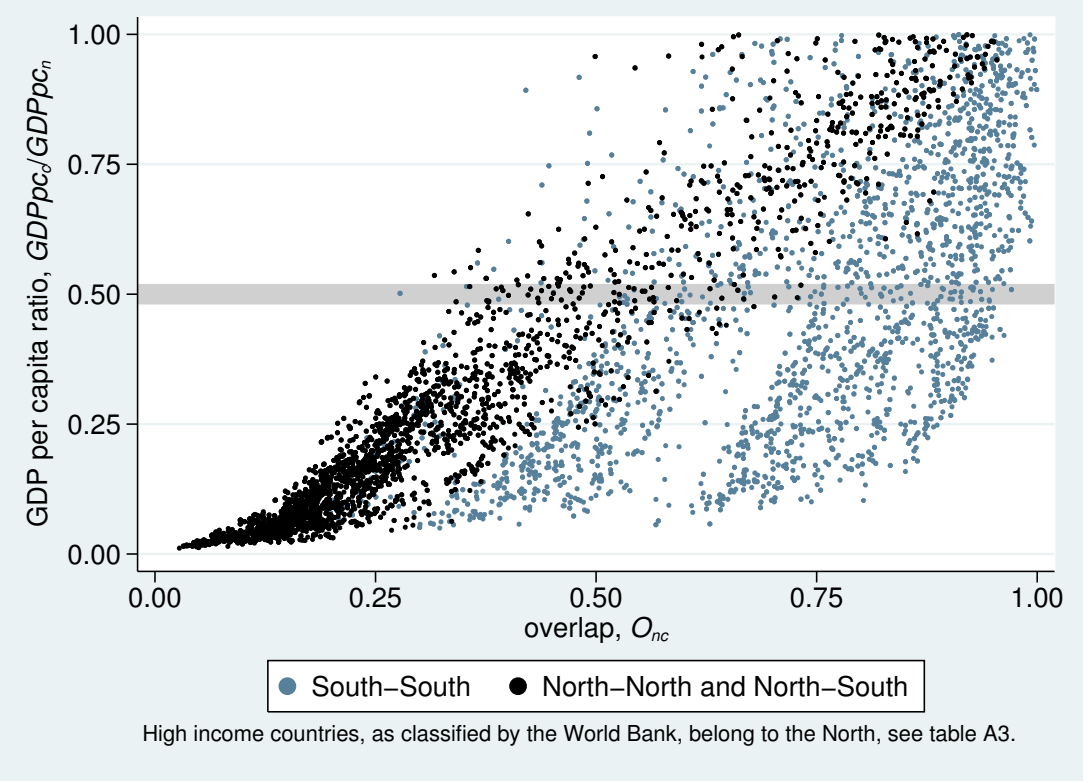

\section{Trade Margins}

\subsection{Trade Data}

The margins of international trade flows are computed with the database of Gaulier \& Zignago (2010) which reports annual bilateral trade flows at the six digit level of the Harmonized System (HS), version 1992, from 1995 until 2007. The original data has been collected by UN Comtrade. If both the importer and the exporter report to Comtrade two, possibly different, figures show up for the same ${ }^{16} \operatorname{corr}\left(O_{n c}, O_{n c}^{\bar{x}}\right)=-0.14, \operatorname{corr}\left(O_{n c}, O_{n c}^{w}\right)=0.18, \operatorname{corr}\left(O_{n c}^{\bar{x}}, O_{n c}^{w}\right)=0.89$ 
trade flow. I use the dataset of Gaulier \& Zignago (2010) because they reconciled double observations into a single harmonized value per trade flow 17 The unit of observation in the data is: importer $(c)$, exporter $(n)$, HS 6-digit code $(i)$, year $(t)$ 18 At this level of disaggregation 5'018 product categories are observed. However, only categories which include consumer goods are used as the rationale for my hypothesis is driven by the demand side. The corresponding classification is taken from CEPII which in turn is based on the classification of Broad Economic Categories 19 1'263 product categories include consumer goods, they correspond to $27 \%$ of worldwide value of trade, in 2002. Examples are cars with large cylinder capacity, microwave ovens or cashew nuts (fresh or dried), see table A1 for more examples. I screen the data as follows: (i) I discard observations which involve countries from which I do not have information on income distribution, (ii) in order to avoid that very small countries dominate the sample I drop countries with a population smaller than one million, (iii) I discard observations of less than US $\$ 2$ '000 as small trade flows are more prone to measurement error. The sample I use accounts for $94 \%$ of the value of worldwide trade in consumer goods. It covers 102 countries at all stages of development - 33 poor, 42 middle income and 27 rich nations, see table A3.

\subsection{Bilateral Trade Margins}

I study both aggregate and disaggregate bilateral trade flows. Aggregate trade margins, $Y_{n c}$, describe the flow from exporter $n$ to importer $c$ in all product categories. One observation reveals, for example, that Japan imports consumer goods from Canada worth 1.24 billion US\$ - all examples refer to 2002. As trade flows differ considerably across product categories I additionally study disaggregate trade flows, $Y_{n c i}$, i.e. flows from exporter $n$ to importer $c$ in a specific category $i$. It is for example recorded that Japan imports cars (with large cylinder capacity, HS 870324) from Canada worth 69 million US\$.

\section{Disaggregate Bilateral Trade Margins, $Y_{n c i}$}

The data contains information on country $c$ 's imports from exporter $n$ in product category $i$. For each trade flow the corresponding value $v_{n c i}$, in thousands of US dollars, is observed. The extensive margin of disaggregate bilateral trade flows $E M_{n c i}$ is an indicator which equals one if $c$ has positive imports from source country $n$ in product category $i$ and zero otherwise.

$$
E M_{n c i}= \begin{cases}1 & \text { if } v_{n c i}>0 \\ 0 & \text { if } v_{n c i}=0\end{cases}
$$

\footnotetext{
${ }^{17}$ They reconcile double observations into a single figure by weighting the values by the reliability of the two reporting countries, where the measure for reliability is based on a variance analysis. Another advantage of this database is that all values are converted to a Free on Board (FOB) basis. Originally imports are reported inclusive of the Cost for Insurance and Freight (CIF) and exports FOB. The authors estimated transport and insurance rates in order to transform CIF values into $\mathrm{FOB}$ values.

${ }^{18}$ In the text below, the terms "HS 6-digit" and "HS6" are used interchangeably.

${ }^{19}$ http://www.cepii.fr/anglaisgraph/bdd/baci/non_restrict/sector.asp
} 
At the disaggregate level there is no difference between the intensive margin and the value as the latter describes trade in a given product category $i$. The intensive margin of a disaggregate bilateral trade flow $I M_{n c i}$ is defined as the value of the respective flow ${ }^{20}$

$$
I M_{n c i}=v_{n c i}
$$

\section{Aggregate Bilateral Trade Margins, $Y_{n c}$}

By summing over product categories aggregate bilateral trade margins are constructed. The value of the overall trade flow from $n$ to $c$ is decomposed into an extensive and intensive margin. Where the extensive margin reflects in how many categories two countries engage in trade, i.e. the diversity of the trade flow, the intensive margin describes how much is traded in the average product. The decomposition of trade values into the two margins is along the lines of Hummels \& Klenow (2005).

The value of country $c$ 's imports from exporter $n$ is normalized by $c$ 's imports from the rest of the world $r$. To give an example, Japan's imports from Canada (1.24 billion US\$) are normalized by Japan's imports from the rest of the world (83.3 billion US\$).

$$
V_{n c}=\frac{\sum_{i \in I} v_{n c i}}{\sum_{i \in I} v_{r c i}}, \quad v_{r c i}=\sum_{\hat{n} \in N_{-n}} v_{\hat{n} c i}
$$

The rest of the world $r$ denotes all countries from which $c$ imports other than $n, N$ designates the set of all exporters and $I$ denotes the set of all product categories containing consumer goods.

The extensive margin $E M_{n c}$ is a weighted count of the product categories which $c$ imports from $n$ relative to the categories which $c$ imports from the rest of the world $r$. Each category $i$ is weighted by $c$ 's imports from the rest of the world $r, v_{r c i}$, to prevent that categories which $c$ predominantly imports from $n$ appear important. As Japan imports only few motorcycles $i=871130$ has a small weight and as Japan imports a lot of cars $i=870324$ has a large weight. Japan imports in 671 categories from Canada and in 1'249 product categories from the rest of the world $r$. If all 1'249 categories were of equal importance, $E M_{\mathrm{CAN}, \mathrm{JPN}}$ would be equal to $671 / 1^{\prime} 249=0.54$. Yet, as those 671 categories imported from Canada are important for Japan as an importer $E M_{\mathrm{CAN}, J P N}$ is higher than 0.54, namely 0.85 .

$$
E M_{n c}=\frac{\sum_{i \in I_{n c}} v_{r c i}}{\sum_{i \in I_{r c}} v_{r c i}}
$$

$I_{n c}\left(I_{r c}\right)$ designates the set of categories in which $c$ has positive imports from $n$ (rest of the world $r$ ).

The intensive margin $I M_{n c}$ compares the value of $c$ 's imports from $n$ to the value of $c$ 's imports from $r$ in a common set of goods, $I_{n c}$. Japan's imports from Canada (1.24 bn US $\$$ ) are normalized by

\footnotetext{
${ }^{20}$ For illustration, while Japan does import motorcycles (with middle cylinder capacity, HS 871130) from Canada it does not from Mexico $\left(E M_{\mathrm{CAN}, \mathrm{JPN}, 871130}=1, E M_{\mathrm{MEX}, \mathrm{JPN}, 871130}=0\right)$. Japan imports cars (HS 870324) from Canada for 69 million US\$ and from Mexico for only 7 million US\$ $\left(I M_{\mathrm{CAN}, \mathrm{JPN}, 870324}=69, I M_{\mathrm{MEX}, \mathrm{JPN}, 870324}=7\right)$.
} 
Japan's imports from the rest of the world in the before mentioned 671 categories (72.6 billion US\$).

$$
I M_{n c}=\frac{\sum_{i \in I_{n c}} v_{n c i}}{\sum_{i \in I_{n c}} v_{r c i}}
$$

The normalized import value is equal to the product of the extensive and intensive margin.

$$
V_{n c}=E M_{n c} \cdot I M_{n c}
$$

Alternatively, unnormalized aggregate bilateral trade margins, $\widetilde{Y}_{n c}$, are defined as simply and intuitively as possible. $\widetilde{V}_{n c}$ denotes the value of $c$ 's overall imports from $n$. $\widetilde{E M}_{n c}$ is defined as the number of product categories in which $c$ has positive imports from source country $n . \widetilde{I M}_{n c}$ reflects the average value per product category ${ }^{21}$ See table A2 for summary statistics of all trade margins.

$$
\widetilde{V}_{n c}=\sum_{i \in I_{n c}} v_{n c i}, \quad \widetilde{E M}_{n c}=\sum_{i \in I_{n c}} E M_{n c i}, \quad \widetilde{I M}_{n c}=\frac{\sum_{i \in I_{n c}} v_{n c i}}{\sum_{i \in I_{n c}} E M_{n c i}}, \quad \widetilde{V}_{n c}=\widetilde{E M}_{n c} \cdot \widetilde{I M}_{n c}
$$

\section{Empirical Model}

I test the hypothesis that countries with more similar demand structures trade more with each other. The prediction is that they trade more in terms of value and along both the extensive and intensive margin. Similarity of demand structures is approximated by similarity of income distributions. I use a cross section of the data to test this hypothesis with an augmented gravity equation, both for aggregate and disaggregate trade flows.

\section{Aggregate Trade Flows, $Y_{n c}$}

Equation $(13)$ is the main specification which is estimated with OLS.

$$
\ln \left(Y_{n c}\right)=\alpha+\beta O_{n c}+\tau_{n c}^{\prime} \gamma+A_{c}+A_{n}+\epsilon_{n c}, \quad Y \in\{V, E M, I M\}
$$

$Y_{n c}$ represents the aggregate bilateral trade flow from exporter $n$ to importer $c$. Each trade margin is regressed on the similarity measure $O_{n c}$ which reflects how much the income distributions of trading partners $c$ and $n$ are alike. The coefficient of interest is $\hat{\beta}$, the marginal effect of similarity of income distributions on bilateral trade. This effect is conditional on trade costs $\tau_{n c}$ and importer as well as exporter fixed effects, $A_{c}$ and $A_{n}$.

The vector which approximates bilateral trade $\operatorname{costs} \tau_{n c}$ includes the standard controls - geographic

\footnotetext{
${ }^{21}$ The importer fixed effects in the regressions absorb, among other things, c's overall imports as well as the overall number of categories imported by $c$. I.e. $\widetilde{Y}_{n c}$ are equivalent to import shares, e.g. $\widetilde{V}_{n c} /\left(\sum_{n \in N} \sum_{i \in I} v_{n c i}\right)$.
} 
distance, dummies for free trade agreement, currency union, common border, common legal system, common language and colonial ties ${ }^{22}$ In addition, $\tau_{n c}$ includes a dummy variable which allows for a different intercept for North-North, South-South and North-South trade flows. This is due to two reasons. First, the distribution of the extensive margin is tremendously different for North-North trade flows compared to South-South or North-South trade flows, see table A5. Second, the distribution of income similarity differs strongly for the three types of trade flows, also when it is conditioned on the other proxies for bilateral trade costs and importer and exporter fixed effects, see table A4. To allow for different intercepts captures these disparities partly. A country belongs to the North if it is classified as a high income country by the World Bank and to the South otherwise, see table $\mathrm{A} 3{ }^{23}$

Importer fixed effects $A_{c}$ control for all factors which are specific to importer $c$, such as importer GDP, importer population, importer production possibilities, importer technology or skills in country c. Likewise exporter fixed effects $A_{n}$ control for all factors which are specific to exporter $n$, such as exporter GDP and population, exporter production possibilities, technology and skills. Hence, the marginal effect of similarity on trade is identified by variation across exporters, for a given importer, and by variation across importers, for a given exporter. Table A3 documents that also within countries the similarity measures vary a lot. For instance, Japan's overlap of its income distribution with the income distribution of its trading partner $\left(O_{n, J P N}\right)$ ranges from $0.05(n=S O M)$ up to $0.88(n=G E R)$.

Regression equation (13) is closely related to a gravity equation. The gravity model predicts that bilateral trade increases in economic size of the trading partners and diminishes in their distance. The economic sizes are captured by the importer and exporter fixed effects, whereas $\tau_{n c}$ absorbs several dimensions of distance, such as geography or language. Thus, the present specification isolates the effect of similarity from standard gravity forces. Moreover, the effect of similarity is not only separated from the effect of economic sizes but also from all other factors which are specific to an importer respectively exporter, such as technology or skills.

Although all three similarity measures are symmetric one-way trade flows are analyzed. The explanatory variable $O_{n c}$ is the same for Japan's imports from Canada as for Canada's imports from Japan. However, the importer and exporter fixed effects are different for the two trade flows. They allow a differential import and export behavior of a given country.

It is well known that a substantial fraction of trade flows is zero. In 2002, I have data for 102 countries, hence there are potentially $10^{\prime} 302$ one-way trade flows. Thereof $74 \%$ are positive, $25 \%$ are zero and for $1 \%$ of the trade flows the data is missing. With a bulk of zeros there is potentially a selection problem, i.e. country pairs which do engage in trade may not be representative for all

\footnotetext{
${ }^{22}$ I use the dataset of Helpman et al. (2008) which is available at http://scholar.harvard.edu/helpman/pages/data-1.

${ }^{23}$ Due to conditioning on importer and exporter fixed effects, which control for whether an importer respectively exporter belongs to the North, only one of the four combinations of North and South is included in equation (13), and one serves as the base group. For the coefficient of interest it does not matter which of the four combinations is included.
} 
country pairs. In order to control for this I apply a simplified version of the semi-parametric analogue of Heckman's two-step estimator which is proposed in Cosslett (1991) ${ }^{24}$ Equation (14) is the first stage and specifies a linear probability model which is estimated with OLS. 1( $\left.V_{n c}>0\right)$ designates an indicator which is equal to 1 if imports of $c$ from $n$ are positive and 0 if $c$ does not import from $n$. The resulting predicted probabilities $w_{n c}^{\prime} \hat{\theta}$ are ranked and assigned into $J$ bins with equal number of observations. The bins are denoted with $I_{j}$. They approximate the selection correction function with a step function, hence nonparametrically and in a very flexible way. (15) is the second stage and nests my baseline specification 13 as it additionally controls for selection with a set of indicator variables representing the $J$ bins $-1\left(w_{n c}^{\prime} \hat{\theta} \in I_{j}\right)$, where $j=1, \ldots, J$. In other words, compared to the baseline specification (15) additionally controls for the probability of a positive trade flow by allowing bin-specific intercepts. Note that the coefficients on the bins, the $\hat{\lambda}_{j}$ 's, shed light on the selection pattern. For instance, if $\hat{\lambda}_{j}$ 's is increasing in $j$ trade flows with a higher probability of being positive have systematically higher trade margins $\left(Y_{n c}\right)$. I choose $J=100$, i.e. I allow a different intercept for each percentile of the predicted probabilities $\left(w_{n c}^{\prime} \hat{\theta}\right)$. Yet, the results are similar for $J=50$ or $J=200$.

$$
\begin{aligned}
1\left(V_{n c}>0\right) & =\alpha+\beta O_{n c}+\tau_{n c}^{\prime} \gamma+\mu z_{n c}+A_{c}+A_{n}+u_{n c} \equiv w_{n c}^{\prime} \theta+u_{n c} \\
\ln \left(Y_{n c}\right) & =\alpha+\beta O_{n c}+\tau_{n c}^{\prime} \gamma+\sum_{j=1}^{J} \lambda_{j} \cdot 1\left(w_{n c}^{\prime} \hat{\theta} \in I_{j}\right)+A_{c}+A_{n}+\epsilon_{n c}
\end{aligned}
$$

$z_{n c}$ is the exclusion restriction. The constellation of religious affiliation is assumed to affect whether $c$ imports from country $n$ but not how much $c$ imports from $n$ or how diverse $c$ 's imports from $n$ are. This common religion variable is taken from Helpman et al. (2008), they use it for the same type of exclusion restriction 25

\section{Disaggregate Trade Flows, $Y_{n c i}$}

As the drivers for trade may differ across goods also disaggregate trade flows are analyzed.

$$
\begin{aligned}
E M_{n c i} & =\alpha+\beta O_{n c}+\tau_{n c}^{\prime} \gamma+A_{c}+A_{n}+A_{i}+\epsilon_{n c i} \\
\ln \left(I M_{n c i}\right) & =\alpha+\beta O_{n c}+\tau_{n c}^{\prime} \gamma+A_{c}+A_{n}+A_{i}+\epsilon_{n c i}
\end{aligned}
$$

The extensive margin on the disaggregate level is a binary variable, $E M_{n c i} \in\{0,1\}$. Its relation to similarity and controls is specified as a linear probability model in equation (16). Also at the

\footnotetext{
${ }^{24}$ The procedure in Cosslett (1991) is as follows. The binary response model, the first stage, is estimated with the nonparametric maximum likelihood estimator in Cosslett (1983). The estimator $\hat{F}(\cdot)$ of the marginal cumulative density function of the selection error is a step function, it is constant on a finite number of intervals, $J$. In the second stage the selection correction function is approximated by a piecewise constant function on those intervals. As the second stage is linear it can be estimated with OLS. Cosslett (1991) shows that the estimator of the first and second stage are consistent.

${ }^{25}$ religion $_{n c}=(\%$ Protestants in country $n \cdot \%$ Protestants in country $c)+(\%$ Catholics in country $n \cdot \%$ Catholics in country $c)+(\%$ Muslims in country $n \cdot \%$ Muslims in country $c), \in[0,1]$.
} 
disaggregate level I regress the margins of bilateral trade on the similarity measure $O_{n c}$ which indicates to which degree the income distributions of $c$ and $n$ are alike. The effect of similarity on trade from $n$ to $c$ in product category $i$ is conditional on bilateral trade costs $\tau_{n c}$ as well as importer, exporter and product category fixed effects, $A_{c}, A_{n}$ and $A_{i}$.

With category fixed effects $A_{i}$ the marginal effects are identified with variation within product categories. The category fixed effects capture all product specific characteristics, for example how difficult it is to transport good $i$ around the world (strawberries versus books), the technology needed to produce the good or the average value of worldwide trade in $i$. For instance, for cars (HS 870324) the average bilateral trade value, worldwide, is 47.8 million US\$ and for curry (HS 091050) 71'260 US\$ .

At the HS 6-digit level $92 \%$ of bilateral trade flows are zero in my sample with 102 countries, in 2002. This poses no problem for estimating the linear probability model for the extensive margin specified in (16) with OLS. However, equation (17) can only be estimated for those $8 \%$ of all potential trade flows which are positive. This is taken into account by applying the simplified version of the semiparametric selection model proposed in Cosslett (1991). The first stage is the linear probability model 16. The predicted probabilities of a positive bilateral disaggregate trade flow, $w_{n c i}^{\prime} \hat{\theta}$, are ranked and assigned into $J$ bins with equal number of observations. The $J$ bins, denoted with $I_{j}$, approximate the selection correction function with a step function, i.e. nonparametrically. The second stage (18) includes all regressors of equation (17) and additionally embeds the selection correction function.

$$
\ln \left(I M_{n c i}\right)=\alpha+\beta O_{n c}+\tau_{n c}^{\prime} \gamma+\sum_{j=1}^{J} \lambda_{j} \cdot 1\left(w_{n c i}^{\prime} \hat{\theta} \in I_{j}\right)+A_{c}+A_{n}+A_{i}+\epsilon_{n c i}
$$

As religious affiliation is not positively related to $c$ 's probability of importing good $i$ from exporter $n$ it cannot be used as an exclusion restriction. Due to lack of a plausible exclusion restriction on the level of products the system is estimated without an exclusion restriction. However, the identification of $\beta$ does not stem from a specific functional form of the selection function - as would for example be the case with the Heckman two-step estimator - as the selection function is nonparametric.

\section{Discussion of Results}

The three main findings of the empirical analysis provide comprehensive and consistent evidence that similarity of demand patterns - approximated by similarity of income distributions - is an important determinant of bilateral trade margins. First, the more the income distributions of two countries overlap, the higher is their bilateral trade volume in consumer goods. This effect is driven by both the extensive and intensive margin (section 5.1). In the main specification $63 \%$ of the effect of income similarity on trade values is due to a higher extensive margin, and the remaining $37 \%$ due to a higher 
intensive margin, of countries with more similar income distributions. My augmented gravity equation conditions on importer and exporter fixed effects as well as trade costs in order to isolate the effect of similarity from supply side effects, such as technology, and from gravity forces, such as trade costs and economic sizes. Second, the two novel measures characterizing the overlap area - the average income level and the width of the overlap - are also positively related to both trade margins (section 5.1). The average income level of the overlap area serves as an additional explanatory variable as it describes the location of the overlap, whereas the width of the overlap area is an alternative measure for income similarity as it reflects how broad the range of incomes is for which two distributions overlap. Third, also the margins of disaggregate trade flows - i.e. trade within product categories - increase in income distribution similarity (section 5.2). Thus, the findings on the aggregate level are reinforced by the results on disaggregate trade flows.

\subsection{Income Similarity and Aggregate Bilateral Trade Margins $\left(Y_{n c}\right)$}

Table 2 reports the OLS coefficients from regression equation (13), based on data of 2002. In column one to three the main measure of similarity is used. On average, countries with a higher overlap of their income distributions have higher bilateral trade values $\left(V_{n c}\right)$, trade a larger variety of goods $\left(E M_{n c}\right)$ and have higher bilateral trade values in a given set of goods $\left(I M_{n c}\right)$.

The first column implies that if the overlap of two income distributions, $O_{n c}$, increases by one standard deviation (0.29) the value of bilateral trade in consumer goods increases by $35 \%$. Respectively, the $\log$ value is raised by 0.11 standard deviations (beta coefficient). This effect is hence both statistically as well as economically highly significant 26 Remember, the marginal effect of the overlap on trade is conditional on importer and exporter fixed effects as well as on trade costs, in order to isolate the effect of income similarity from supply side effects and gravity forces.

Decomposing bilateral trade values into the two margins demonstrates that the positive association between the overlap and trade volumes is driven by both the extensive and intensive margin. As $V_{n c}=E M_{n c} I M_{n c}$ and as the dependent variables are in logarithms the OLS coefficients of the two margins add up to the coefficient of trade values. On average, countries with a one standard deviation higher overlap trade a $22 \%$ more diversified bundle of goods (extensive margin) and trade $13 \%$ more within a given set of goods (intensive margin). $63 \%(0.755 / 1.204)$ of the effect of a larger overlap on higher trade values is due to a higher extensive margin of countries with more similar income distributions. And $37 \%$ of the effect are attributed to the intensive margin. With a beta coefficient of 0.1 for the extensive and 0.06 for the intensive margin the effects are not only of statistical but also of economic importance.

\footnotetext{
${ }^{26}$ The overlap ranges from 0 to 1 , with mean 0.49 and standard deviation 0.29. For illustration, while Japan's overlap with Hungary amounts to 0.47 - which is about the mean of $O_{n c}$ - it is 0.78 with Hong Kong. I.e. the overlap with Hong Kong is 0.31 , or about one standard deviation, higher than the overlap with Hungary.
} 
Table 2: $Y_{n c}-$ Main Specification

\begin{tabular}{|c|c|c|c|c|c|c|c|c|c|}
\hline & $\ln \left(V_{n c}\right)$ & $\ln \left(E M_{n c}\right)$ & $\ln \left(I M_{n c}\right)$ & $\ln \left(V_{n c}\right)$ & $\ln \left(E M_{n c}\right)$ & $\ln \left(I M_{n c}\right)$ & $\ln \left(V_{n c}\right)$ & $\ln \left(E M_{n c}\right)$ & $\ln \left(I M_{n c}\right)$ \\
\hline Mean & -7.171 & -2.639 & -4.532 & -7.171 & -2.639 & -4.532 & -7.171 & -2.639 & -4.532 \\
\hline St. dev. & 3.106 & 2.276 & 2.026 & 3.106 & 2.276 & 2.026 & 3.106 & 2.276 & 2.026 \\
\hline$O_{n c}$ & $\begin{array}{l}1.204^{\star \star \star} \\
(0.138)\end{array}$ & $\begin{array}{l}0.755^{\star \star \star} \\
(0.138)\end{array}$ & $\begin{array}{l}0.449^{\star \star \star} \\
(0.128)\end{array}$ & $\begin{array}{l}0.838^{\star \star \star} \\
(0.142)\end{array}$ & $\begin{array}{l}0.518^{\star \star \star} \\
(0.144)\end{array}$ & $\begin{array}{l}0.320^{\star \star} \\
(0.136)\end{array}$ & & & \\
\hline$O_{n c}^{\bar{x}}$ & & & & $\begin{array}{l}0.392^{\star \star \star} \\
(0.050)\end{array}$ & $\begin{array}{l}0.254^{\star \star \star} \\
(0.049)\end{array}$ & $\begin{array}{l}0.138^{\star \star \star} \\
(0.046)\end{array}$ & & & \\
\hline$O_{n c}^{w}$ & & & & & & & $\begin{array}{l}0.114^{\star \star \star} \\
(0.012)\end{array}$ & $\begin{array}{l}0.065^{\star \star \star} \\
(0.012)\end{array}$ & $\begin{array}{l}0.048^{\star \star \star} \\
(0.010)\end{array}$ \\
\hline \# obs. & 7,630 & 7,630 & 7,630 & 7,630 & 7,630 & 7,630 & 7,630 & 7,630 & 7,630 \\
\hline \# regr. & 212 & 212 & 212 & 213 & 213 & 213 & 212 & 212 & 212 \\
\hline Adj. $R^{2}$ & 0.767 & 0.601 & 0.507 & 0.769 & 0.602 & 0.508 & 0.767 & 0.601 & 0.508 \\
\hline
\end{tabular}

Notes: ${ }^{\star \star \star},{ }^{\star \star},{ }^{\star}$ denote statistical significance on the $1 \%, 5 \%$, and $10 \%$ level, respectively. Robust standard errors (clustered by country pairs) are given in parentheses. Controls: geographic distance, dummies for free trade agreement, currency union, common border, common legal system, common language, colonial ties, dummy variable allowing for a different intercept for NN, SS, NS and SN trade flows $\left(\tau_{n c}\right)$, importer and exporter fixed effects $\left(A_{c}\right.$ and $\left.A_{n}\right)$. Sample: countries with population $>1$ million, HS6 codes which include consumer goods. Year=2002. Income distributions are calculated with quintile and decile data from 1992 until 2002. This table reports the estimation results from equation (13). The dependent variables are defined in equations (9)-(11). The income similarity measures are defined in equations (4)-(6).

In column four to six it is shown that not only the extent to which two income distributions overlap but also at which income levels the overlap is concentrated matters for trade. Additionally controlling for the average income level of the overlap area, $O_{n c}^{\bar{x}}$, somewhat reduces the marginal effects of the overlap, however, without altering their statistical or economical significance. But importantly, the value and both the extensive and intensive margin of bilateral trade flows are larger for country pairs which income distributions overlap at higher income levels, conditional on the size of the overlap ${ }^{27}$ Quantitatively, for a given size of the overlap, the bilateral trade value is $36 \%$ higher for a country pair with a one standard deviation higher average income of the overlap area (9'100). Almost two thirds of this effect is due to a higher extensive margin and one third is due to a higher intensive margin.

The width of the overlap area, $O_{n c}^{w}$, is used as an alternative measure for income similarity as it represents the range of incomes for which two distributions overlap and hence captures, in a simple way, how similar two income distributions are. The last three columns of table 2 document that the results are qualitatively the same when I use this alternative measure for income similarity ${ }^{28}$ An increase of one standard deviation in the width of the overlap (36'300) is, on average, associated with a $41 \%$ higher trade value. Again, the increase in the value is due to both a larger extensive (24\%) and a larger intensive margin (17\%).

Note that the vector $\tau_{n c}$, which approximates bilateral trade costs, is omitted in all tables. All coefficients have the expected sign and are significantly different from zero. Standard errors are clus-

\footnotetext{
${ }^{27} O_{n c}^{\bar{x}}$ ranges from 2'500 to 45'050, with a standard deviation of 9'100. For illustration, while the area of Japan's overlap with both Mexico and Poland is 0.36 the average income level of the overlap area with Mexico is 9'000 larger than with Poland (28'600 versus 19'700).

${ }^{28} O_{n c}^{w}$ goes from 5'000 to 150 '000, with mean $48^{\prime} 700$ and standard deviation $36{ }^{\prime} 300$. For illustration, the width of the overlap of Japan-Bulgaria is 45'000. As the distribution of the Dominican Republic is more skewed it overlaps with Japan up to incomes of $80^{\prime} 000$, which is about one standard deviation more than the width of Japan-Bulgaria.
} 
tered by two-way country pairs, i.e. $\epsilon_{n c}$ and $\epsilon_{c n}$ are allowed to be correlated. This might be the case if there is a country pair specific shock, such as a bilateral political dispute, which lowers country $c$ 's imports from $n$ as well as country $n$ 's imports from $c{ }^{29}$

Before I address the zeros in trade data, I outline in this paragraph that the above findings are very robust. Table 3 displays that the results are qualitatively the same for unnormalized trade margins which are computed in a simple and intuitive way. A country imports more from source countries with a higher overlap, not only in terms of value but also along both margins 30 Moreover, for a given overlap of income distributions, the higher the average income level of the overlap area, the larger are bilateral trade margins. Last, the broader the range of incomes for which two income distributions overlap, the larger is the bilateral trade value. Also this effect is driven by both margins.

Table 3: $\widetilde{Y}_{n c}$ - Main Specification with Unnormalized Trade Margins

\begin{tabular}{|c|c|c|c|c|c|c|c|c|c|}
\hline & $\ln \left(\widetilde{V}_{n c}\right)$ & $\ln \left(\widetilde{E M}_{n c}\right)$ & $\ln \left(\widetilde{I M}_{n c}\right)$ & $\ln \left(\widetilde{V}_{n c}\right)$ & $\ln \left(\widetilde{E M}_{n c}\right)$ & $\ln \left(\widehat{I M}_{n c}\right)$ & $\ln \left(\widetilde{V}_{n c}\right)$ & $\ln \left(\widetilde{E M}_{n c}\right)$ & $\ln \left(\widehat{I M}_{n c}\right)$ \\
\hline Mean & 7.792 & 3.301 & 4.491 & 7.792 & 3.301 & 4.491 & 7.792 & 3.301 & 4.491 \\
\hline St. dev. & 3.384 & 2.040 & 1.700 & 3.384 & 2.040 & 1.700 & 3.384 & 2.040 & 1.700 \\
\hline$O_{n c}$ & $\begin{array}{l}1.216^{\star \star \star} \\
(0.137)\end{array}$ & $\begin{array}{l}0.646^{\star \star \star} \\
(0.079)\end{array}$ & $\begin{array}{l}0.570^{\star \star \star} \\
(0.095)\end{array}$ & $\begin{array}{l}0.848^{\star \star \star} \\
(0.141)\end{array}$ & $\begin{array}{l}0.502^{\star \star \star} \\
(0.083)\end{array}$ & $\begin{array}{l}0.346^{\star \star \star} \\
(0.099)\end{array}$ & & & \\
\hline$O_{n c}^{\bar{x}}$ & & & & $\begin{array}{l}0.392^{\star \star \star} \\
(0.050)\end{array}$ & $\begin{array}{l}0.153^{\star \star \star} \\
(0.029)\end{array}$ & $\begin{array}{l}0.238^{\star \star \star} \\
(0.035)\end{array}$ & & & \\
\hline$O_{n c}^{w}$ & & & & & & & $\begin{array}{l}0.115^{\star \star \star} \\
(0.012)\end{array}$ & $\begin{array}{l}0.047^{\star \star \star} \\
(0.007)\end{array}$ & $\begin{array}{l}0.068^{\star \star \star} \\
(0.008)\end{array}$ \\
\hline \# obs. & 7,656 & 7,656 & 7,656 & 7,656 & 7,656 & 7,656 & 7,656 & 7,656 & 7,656 \\
\hline \# regr. & 212 & 212 & 212 & 213 & 213 & 213 & 212 & 212 & 212 \\
\hline Adj. $R^{2}$ & 0.804 & 0.837 & 0.574 & 0.806 & 0.838 & 0.576 & 0.804 & 0.836 & 0.576 \\
\hline
\end{tabular}

Notes: The same notes apply as in table 2 The only difference is that the dependent variables are defined in equation 12 .

In order to show that the identified effect really captures similarity of income distributions, and not similarity of average incomes, I additionally control for the ratio of per capita incomes. Qualitatively this does not change the results, see table A6. There is one exception, the effect of the overlap on the extensive margin is not significantly different from zero for normalized trade margins. However, for unnormalized trade margins also the results about the extensive margin are unchanged.

The above results, which are based on data of 2002, are both qualitatively and quantitatively representative for the whole period 1995 to 2007. In each and every year, trade values increase significantly in similarity of income distributions, for all measures of similarity. In all years, this effect is driven by both the extensive and intensive margin. This is true for normalized as well as unnormalized

\footnotetext{
${ }^{29}$ One might be worried that the error terms of an importing country are not independent because of a shock of the following type. A recession lowers c's import demand resulting in a slightly negative effect on countries exporting necessity goods to $c$ and a large negative effect on exporters selling durable goods to $c$. Although the average effect of the recession is captured by the importer fixed effect the differential effects on exporters leads to correlated error terms. To account for this, and analogously correlated errors of an exporting country, I clustered the standard errors both by importers and exporters. This increases the standard errors, however does not affect the significance levels.

${ }^{30}$ The marginal effects are quantitatively very similar for normalized and unnormalized trade values as most of the difference between $V_{n c}$ and $\widetilde{V}_{n c}$ is captured by the importer fixed effects.
} 
trade margins, see table A7 and A8. Moreover, pooling all cross sections and including importer-year and exporter-year fixed effects yields very similar results to using only one cross section, see table A9 ${ }^{31}$

Next, it is shown that taking into account the zeros in the estimation procedure does not alter the main findings. In table 4 I apply the simplified version of the semi-parametric selection model of Cosslett (1991) described in section 4. The only difference to the baseline are the bin-specific intercepts which represent the probability that a trade flow is positive and approximate the selection function non-parametrically. The first panel reports the results for normalized trade margins $\left(Y_{n c}\right)$. The value of bilateral trade flows increases significantly in income similarity, $O_{n c}$, if the zeros are taken into account. Even the magnitude of the marginal effect is close to the baseline estimation. Controlling for selection lowers the marginal effect of similarity on the intensive margin and raises the marginal effect on the extensive margin. The effect on the intensive margin is estimated very imprecisely. The coefficients on the bin-specific intercepts $\left(\hat{\lambda}_{j}\right)$ disclose that trade flows which have a higher probability to be positive have systematically a lower intensive and higher extensive margin. Additionally controlling for the average income level of the overlap area again lowers the marginal effects of the overlap and shows that the extensive and value margin are larger for country pairs whose overlap is concentrated at higher incomes, $O_{n c}^{\bar{x}}$. Controlling for selection does not alter the results when similarity is measured with the width of the overlap $O_{n c}^{w}$.

Selection seems to be less of an issue for unnormalized trade margins $\left(\widetilde{Y}_{n c}\right)$, see second panel. Income similarity has a significantly positive effect on trade values. This effect is driven by both margins and is qualitatively the same for all measures of similarity. The effects are rather close to the baseline OLS estimates as there is no clear selection pattern for the intensive margin and as the extensive margin is only slightly higher for trade flows with a higher probability of being positive.

The number of bins $J$ is 100 , yet the results are alike for $J=50$ or $J=200$. Moreover, estimates which do not rely on an exclusion restriction are similar. The first stage indicates that whether two countries engage in trade depends negatively on similarity. However, the effect is very small and not even significantly different from zero when additionally controlling for average income of the overlap.

Last, I outline that the patterns described above hold for trade in various industries. Aggregate bilateral trade margins are computed for each section of the Standard International Trade Classification (SITC) ${ }^{32}$ There are three interesting points about table 5. (i) Estimating the augmented gravity equation (13) for each section of SITC separately unfolds that the overlap of income distributions

\footnotetext{
${ }^{31}$ Note that the qualitative results of table 2 and 3 are also unchanged if equation $\sqrt{13}$ is specified as a log-log instead of log-lin model or if observations are weighted by the total population of the country pair.

${ }^{32}$ Trade margins are calculated analogously to equations $(9)-\sqrt{11}$ for each section of the SITC (SITC 1-digit codes). For two reasons the SITC rather than the HS classification is used to analyze trade flows in different industries. (i) The SITC classifies commodities according to their stage of production, whereas the HS nomenclature is based on the nature of the commodity. (ii) At the 1-digit level there are 10 codes for the SITC and 21 for the HS.
} 


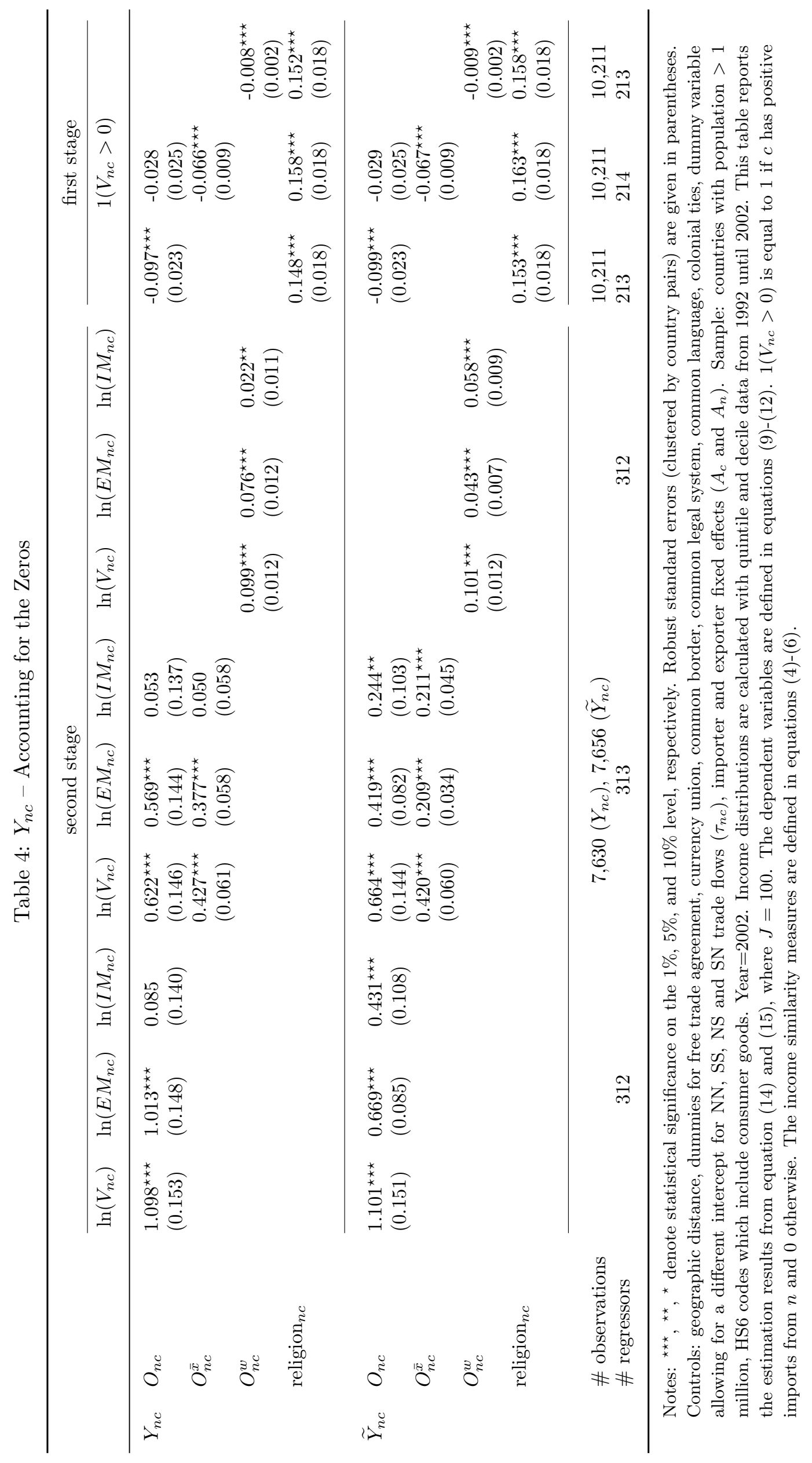




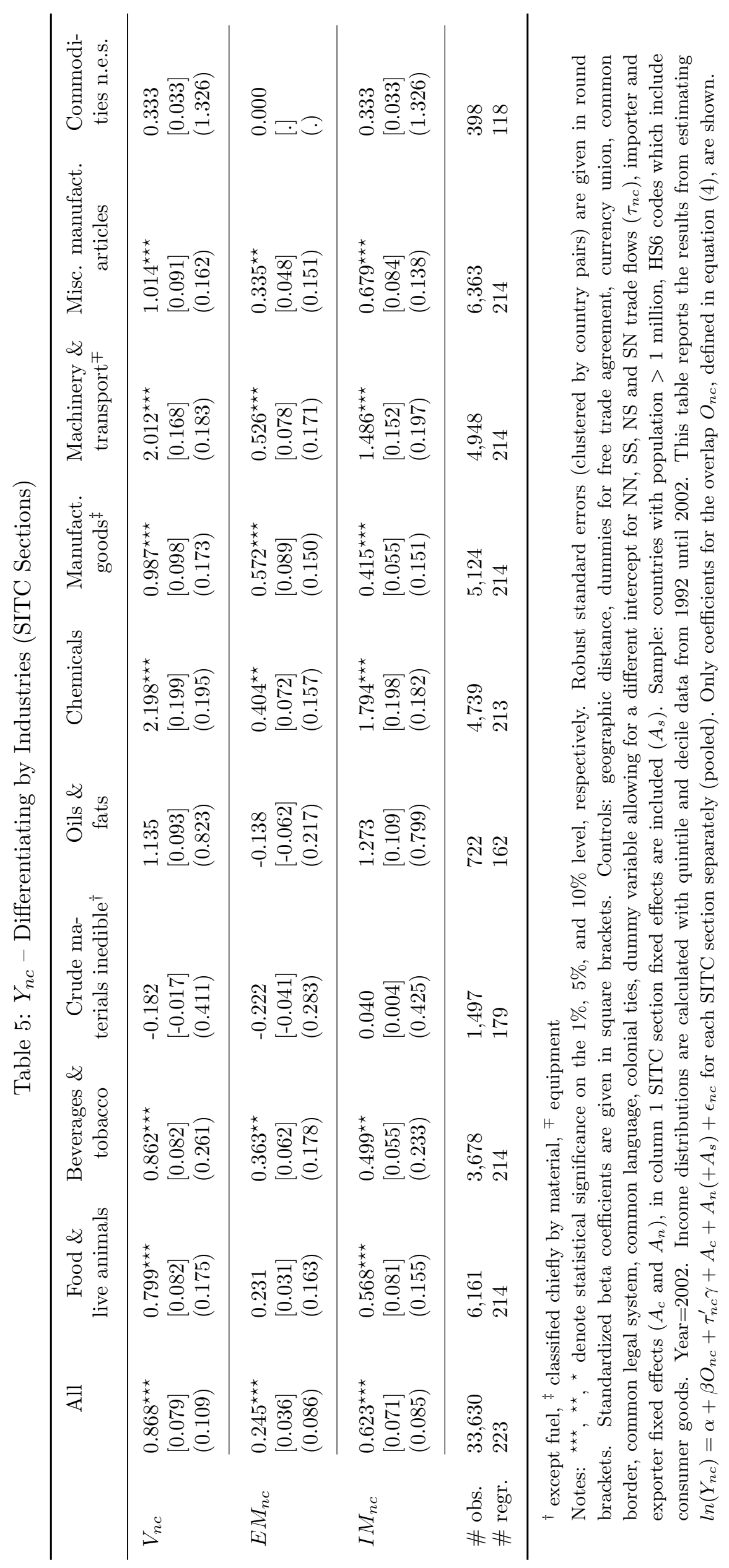


is significantly positively associated with bilateral trade values for all SITC sections except crude materials, oils \& fats and commodities n.e.s. The effects on trade values are driven by both the extensive and intensive margin. (ii) The effect of income similarity on trade is largest for chemicals, followed by machinery and transport equipment and manufactured goods. (iii) Estimating a pooled regression, and controlling for SITC section fixed effects (column one), confirms the qualitative results for overall trade flows. That there is no effect of income similarity in industries containing mostly unprocessed goods, and that the effect is largest in industries including highly differentiated products - such as chemicals or machinery and transport equipment - is in favor of the hypothesis. 33

\subsection{Income Similarity and Disaggregate Bilateral Trade Margins $\left(Y_{n c i}\right)$}

In this section it is shown that also the extensive and intensive margin of disaggregate bilateral trade flows, i.e. trade within product categories, increase in similarity of income distributions. At the disaggregate level the extensive margin $E M_{n c i}$ is an indicator which equals 1 if country $c$ does import product category $i$ from source country $n$. The intensive margin $I M_{n c i}$ is the value of $c$ 's imports in product $i$ from exporter $n$. Within product categories, i.e. at the disaggregate level, there is no difference between the value and the intensive margin.

Table 6 documents that country $c$ has a significantly higher probability to import a given product from those source countries which have an alike income distribution. Column one implies that, on average, an increase of one standard deviation in the overlap $O_{n c}(0.29)$ is associated with a 3.4 percentage point higher probability of bilaterally importing a product. With a beta coefficient of 0.13 this effect is both statistically and economically highly significant. Moreover, the probability to import a given product from a given exporter does not only increase in the overlap but it is also higher if the exports stem from source countries with which the overlap is concentrated at higher income levels, $O_{n c}^{\bar{x}}$. For a given size of the overlap, an increase of the average income level of the overlap area of one standard deviation is associated with a 1.6 percentage point higher probability of a positive trade flow. Measuring the degree to which two income distributions are alike with the width of the overlap, $O_{n c}^{w}$, yields the same implication. An increase of one standard deviation in the width of the overlap raises the probability of importing a given product from a given exporter by 2.9 percentage point.

For the results on the intensive margin it matters a lot whether selectivity is accounted for. The OLS model specified in equation (17) implies that there is no, or even a negative, relation between similarity of income distributions and the bilateral trade value within a product category. However, controlling for the non-parametric selection function (Cosslett), as described in section 4, changes the findings completely. Conditioning on the predicted probability that a trade flow is positive (bin specific intercepts) implies that the value of a country's imports in a given product is significantly higher when

\footnotetext{
${ }^{33}$ For lack of space the corresponding results for unnormalized trade margins and other measures of income similarity are not reported as they yield qualitatively the same insights.
} 
Table 6: $Y_{n c i}$ - Main Specification

\begin{tabular}{|c|c|c|c|c|c|c|c|c|c|}
\hline \multirow{3}{*}{$\begin{array}{l}\text { Mean } \\
\text { St. dev. }\end{array}$} & \multirow{3}{*}{$\begin{array}{l}E M_{n c i} \\
0.079 \\
0.270\end{array}$} & \multirow{2}{*}{\multicolumn{2}{|c|}{$\begin{array}{c}\ln \left(I M_{n c i}\right) \\
3.841 \\
2.187\end{array}$}} & \multirow{3}{*}{$\begin{array}{l}E M_{n c i} \\
0.079 \\
0.270\end{array}$} & \multirow{2}{*}{\multicolumn{2}{|c|}{$\begin{array}{c}\ln \left(I M_{n c i}\right) \\
3.841 \\
2.187\end{array}$}} & \multirow{3}{*}{$\begin{array}{l}E M_{n c i} \\
0.079 \\
0.270\end{array}$} & \multirow{2}{*}{\multicolumn{2}{|c|}{$\begin{array}{c}\ln \left(I M_{n c i}\right) \\
3.841 \\
2.187\end{array}$}} \\
\hline & & & & & & & & & \\
\hline & & OLS & Cosslett & & OLS & Cosslett & & OLS & Cosslett \\
\hline$O_{n c}$ & $\begin{array}{l}0.118^{\star \star \star} \\
(0.006)\end{array}$ & $\begin{array}{l}-0.074 \\
(0.090)\end{array}$ & $\begin{array}{l}0.296^{\star \star \star} \\
(0.106)\end{array}$ & $\begin{array}{l}0.099^{\star \star \star} \\
(0.008) \\
0.018^{\star \star \star} \\
(0.004)\end{array}$ & $\begin{array}{l}0.009 \\
(0.091) \\
-0.120^{\star \star \star} \\
(0.034)\end{array}$ & $\begin{array}{l}0.213^{\star \star} \\
(0.105) \\
0.080^{\star \star} \\
(0.035)\end{array}$ & & & \\
\hline Selection? & & No & Yes & & No & Yes & $\begin{array}{l}0.008^{\star \star \star} \\
(0.001)\end{array}$ & $\begin{array}{c}-0.027^{\star \star \star} \\
(0.007) \\
\text { No }\end{array}$ & $\begin{array}{c}0.015^{\star} \\
(0.008) \\
\text { Yes }\end{array}$ \\
\hline $\begin{array}{l}\text { \# obs. } \\
\text { \# regressors } \\
\text { Adjusted } \mathrm{R}^{2}\end{array}$ & $\begin{array}{l}12990822 \\
1475 \\
0.310\end{array}$ & $\begin{array}{l}1028150 \\
1474 \\
0.300\end{array}$ & $\begin{array}{l}1028150 \\
1574 \\
0.326\end{array}$ & $\begin{array}{l}12990822 \\
1476 \\
0.311\end{array}$ & $\begin{array}{l}1028150 \\
1475 \\
0.300\end{array}$ & $\begin{array}{l}1028150 \\
1575 \\
0.326\end{array}$ & $\begin{array}{l}12990822 \\
1475 \\
0.308\end{array}$ & $\begin{array}{l}1028150 \\
1474 \\
0.300\end{array}$ & $\begin{array}{l}1028150 \\
1574 \\
0.326\end{array}$ \\
\hline
\end{tabular}

Notes: ${ }^{\star \star \star},{ }^{\star \star},{ }^{\star}$ denote statistical significance on the $1 \%, 5 \%$, and $10 \%$ level, respectively. Robust standard errors (clustered by country pairs) are given in parentheses. Controls: geographic distance, dummies for free trade agreement, currency union, common border, common legal system, common language, colonial ties, dummy variable allowing for a different intercept for NN, SS, NS and SN trade flows $\left(\tau_{n c}\right)$, importer, exporter and HS6 code fixed effects $\left(A_{c}, A_{n}\right.$ and $\left.A_{i}\right)$. Sample: countries with population $>1$ million, HS6 codes which include consumer goods. Year=2002. Income distributions are calculated with quintile and decile data from 1992 until 2002. This table reports the estimation results from equation [16, 17] and (18, where $J=100$. The dependent variables are defined in equation $(7)$ and (8). The income similarity measures are defined in equations (4)- 6 .

they stem from source countries which have a more similar income distribution. Quantitatively, a one standard deviation larger overlap is associated with a $8.5 \%$ higher trade value, within a category. The estimates on the bin-specific intercepts $\left(\hat{\lambda}_{j}\right)$ unfold that trade flows with a higher probability of being positive have systematically and substantially lower trade values. This falling selection pattern constitutes a downward bias for the OLS estimate in column two. Controlling for selection moreover unfolds that countries import more from exporters with which their income distribution overlaps at higher incomes. Also the width of the overlap raises disaggregate trade values significantly. The number of bins $J$ is 100 , yet the results are qualitatively similar for $J=50$ or $J=200$.

Bilateral trade costs are omitted in all tables, the coefficients have the same sign as on the aggregate level. Standard errors are again clustered by two-way country pairs 34

Thus, both aggregate bilateral trade flows as well as bilateral trade flows within a given product category increase at both margins in similarity of income distributions.

In table 7 the same analysis is shown for higher levels of aggregation. At the 4-digit level $E M_{n c i}$ represents whether or not $c$ does import HS4 code $i$ from $n 35$ That a country is more likely to import a given category from source countries with more similar income distributions holds for all levels of aggregation (HS6, HS4, HS2, HS1) and for both measures of income similarity. Furthermore, for all levels of aggregation, this probability increases in the average income level of the overlap area.

\footnotetext{
${ }^{34}$ Clustering the standard errors by importer, exporter and HS6 codes does not change the significance level for the extensive margin. However, the coefficients on the intensive margin have a p-value larger than 0.1.

${ }^{35}$ The HS has four hierarchical levels. The 1-digit level corresponds to sections, the 2-digit level represents chapters, the 4-digit codes identify headings and the 6-digit codes represent sub-headings.
} 
Table 7: $Y_{n c i}-$ Level of Aggregation

\begin{tabular}{|c|c|c|c|c|c|c|c|c|c|c|}
\hline & & $E M_{n c i}$ & $\ln (I$ & $\left.I_{n c i}\right)$ & $E M_{n c i}$ & $\ln (I$ & $\left.\Lambda_{n c i}\right)$ & $E M_{n c i}$ & $\ln (I$ & $\left.I_{n c i}\right)$ \\
\hline & & & OLS & Cosslett & & OLS & Cosslett & & OLS & Cosslett \\
\hline HS4 & $O_{n c}$ & $\begin{array}{l}0.171^{\star \star \star} \\
(0.008)\end{array}$ & $\begin{array}{l}0.215^{\star \star} \\
(0.091)\end{array}$ & $\begin{array}{l}0.503^{\star \star \star} \\
(0.116)\end{array}$ & $\begin{array}{l}0.129^{\star \star \star} \\
(0.010)\end{array}$ & $\begin{array}{l}0.277^{\star \star \star} \\
(0.094)\end{array}$ & $\begin{array}{l}0.379^{\star \star \star} \\
(0.109)\end{array}$ & & & \\
\hline & $O_{n c}^{\bar{x}}$ & & & & $\begin{array}{l}0.039^{\star \star \star} \\
(0.004)\end{array}$ & $\begin{array}{l}-0.081^{\star \star} \\
(0.034)\end{array}$ & $\begin{array}{l}0.151^{\star \star \star} \\
(0.037)\end{array}$ & & & \\
\hline & $O_{n c}^{w}$ & & & & & & & $\begin{array}{l}0.013^{\star \star \star} \\
(0.001)\end{array}$ & $\begin{array}{l}-0.008 \\
(0.007)\end{array}$ & $\begin{array}{l}0.029^{\star \star \star} \\
(0.009)\end{array}$ \\
\hline HS2 & & $\begin{array}{l}0.212^{\star \star \star} \\
(0.009)\end{array}$ & $\begin{array}{l}0.560^{\star \star \star} \\
(0.090)\end{array}$ & $\begin{array}{l}0.693^{\star \star \star} \\
(0.118)\end{array}$ & $\begin{array}{l}0.150^{\star \star \star} \\
(0.010)\end{array}$ & $\begin{array}{l}0.495^{\star \star \star} \\
(0.093)\end{array}$ & $\begin{array}{l}0.524^{\star \star \star} \\
(0.110)\end{array}$ & & & \\
\hline & $O_{n c}^{\bar{x}}$ & & & & $\begin{array}{l}0.058^{\star \star \star} \\
(0.004)\end{array}$ & $\begin{array}{l}0.077^{\star \star} \\
(0.033)\end{array}$ & $\begin{array}{l}0.150^{\star \star \star} \\
(0.040)\end{array}$ & & & \\
\hline & $O_{n c}^{w}$ & & & & & & & $\begin{array}{l}0.018^{\star \star \star} \\
(0.001)\end{array}$ & $\begin{array}{l}0.030^{\star \star \star} \\
(0.007)\end{array}$ & $\begin{array}{l}0.036^{\star \star \star} \\
(0.010)\end{array}$ \\
\hline HS1 & $O_{n c}$ & $\begin{array}{l}0.226^{\star \star \star} \\
(0.011)\end{array}$ & $\begin{array}{l}0.867^{\star \star \star} \\
(0.098)\end{array}$ & $\begin{array}{l}0.442^{\star \star \star} \\
(0.123)\end{array}$ & $\begin{array}{l}0.165^{\star \star \star} \\
(0.012)\end{array}$ & $\begin{array}{l}0.683^{\star \star \star} \\
(0.100)\end{array}$ & $\begin{array}{l}0.446^{\star \star \star} \\
(0.115)\end{array}$ & & & \\
\hline & $O_{n c}^{\bar{x}}$ & & & & $\begin{array}{l}0.058^{\star \star \star} \\
(0.005)\end{array}$ & $\begin{array}{l}0.209^{\star \star \star} \\
(0.035)\end{array}$ & $\begin{array}{l}0.013 \\
(0.041)\end{array}$ & & & \\
\hline & $O_{n c}^{w}$ & & & & & & & $\begin{array}{l}0.019^{\star \star \star} \\
(0.001)\end{array}$ & $\begin{array}{l}0.064^{\star \star \star} \\
(0.008)\end{array}$ & $\begin{array}{l}0.013 \\
(0.010)\end{array}$ \\
\hline
\end{tabular}

Notes: The same notes apply as in table 6. The only difference is that here we have HS4, H2 respectively HS1 codes.

Regarding the intensive margin the results are qualitatively the same on all levels of aggregation if it is conditioned on the selection function - countries import systematically more from exporters with more similar income distributions, within categories. As mentioned above, the 6-digit OLS results imply no or a negative association between similarity and bilateral trade values. In contrast, on higher levels of aggregation (HS4, HS2, HS1) the relation is positive. Because of the following two features of articles of apparel (HS2 codes 61 and 62) the OLS results on the 6-digit level are biased downwards. (i) Due to the fine customs structure for articles of apparel they are artificially detailed and hence have disproportionately many HS6 codes within HS4 codes, see also Cadot et al. (2011). ${ }^{36}$ Recall that the Harmonized System is not only used for the collection of trade statistics but also serves as a basis for customs tariffs. (ii) Trade values in apparel are negatively related to similarity. Estimating equation 177 for each HS4 code separately yields $313 \hat{\beta}_{i}$ 's, see table A10. While a HS4 code including apparel has on average a negative coefficient (-0.79), the average effect of all other HS4 codes is positive (0.27). In sum, the negative relation of trade in apparel and similarity gets too much weight on the 6-digit level because apparel is artificially detailed due to customs tariffs ${ }^{37}$ That the consequential

\footnotetext{
${ }^{36}$ Whereas a HS4 code including apparel is on average split into 6.9 HS6 codes, a HS4 code without apparel has on average only 3.7 HS6 codes. For illustration, "women's or girls' suit, dress, skirt, etc, knit or crochet" (6104) is broken down into 25 HS6 codes, e.g. women's or girls' ensembles of wool, knit (610421). In contrast, "Grape wines, alcoholic grape must" (2204) has only four sub-headings, e.g. sparkling wine (220410).

${ }^{37}$ Figure A5 illustrates that HS4 codes with a negative coefficient have disproportionately many sub-headings and that this is driven by articles of apparel.
} 
downward bias on the HS6 OLS coefficient (pooled regression) is sizeable is demonstrated in table A11. Estimating (16)-(18) separately for apparel and non-apparel shows that income similarity has a significantly positive effect on the intensive margin for all products but apparel (1'028 HS6 codes) and a significantly negative effect for apparel (233 HS6 codes), for both OLS and Cosslett.

The findings on disaggregate trade margins are robust. In table A12 I additionally control for similarity of average incomes. As this does not change the results the above effects really reflect similarity in income distributions. The findings above are based on data of 2002. The results on the extensive margin are extremely robust regarding time. In all years, I find a significantly positive relationship between similarity in income distributions and the probability of a positive trade flow, for all measures of similarity, see table A13. Furthermore, pooling all cross sections, and including importer-year and exporter-year fixed effects, also shows that the results for 2002 are both qualitatively and quantitatively representative for the whole period 1995 to 2007, see first panel of table A14. Regarding the intensive margin, in some years the results are not as supportive as in 2002. In some years the marginal effect of the overlap on the intensive margin is significantly positive, in some it is positive but insignificant and in some the estimator is very imprecise. Pooling all cross sections yields a positive but insignificant effect of the overlap on the intensive margin. However, the alternative similarity measure, $O_{n c}^{w}$, is significantly positively related to the intensive margin in all years, and also if all cross sections are pooled. Moreover, the second to fourth panel of table A14 document that for the HS 4-, 2- and 1-digit level the year 2002 is representative for the whole period 1995 to 2007.38

After having demonstrated that income similarity raises both the extensive and intensive margin within product categories, on all levels of disaggregation, I outline that this holds also within various industries. Equations (16)-(18) are estimated for each section of the SITC separately. I.e. all HS6 codes belonging to an SITC section are pooled in one regression. Let me highlight two main findings from table 8. (i) Documenting a positive and highly significant relation between income similarity and the probability to import a given product from a given exporter for each and every SITC section provides strong evidence for my hypothesis that more similar demand structures increase trade. Moreover, the effect is largest for chemicals, machinery and transport equipment and manufacturing goods, i.e. in industries with highly differentiated products. (ii) The intensive margin of bilateral trade is significantly higher for country pairs with more similar income distributions in all SITC sections but crude materials, manufactured goods, miscellaneous manufactured articles, commodities n.e.s. That trade in crude materials and commodities n.e.s. does not increase in similarity does not challenge the supportive evidence for the hypothesis. The result of miscellaneous manufactured articles is non-

\footnotetext{
${ }^{38}$ Note that the qualitative results of table 6 are unchanged if income similarity is used in logs in equation 16, , 17. and 18 or if observations are weighted by the total population of the country pair.
} 


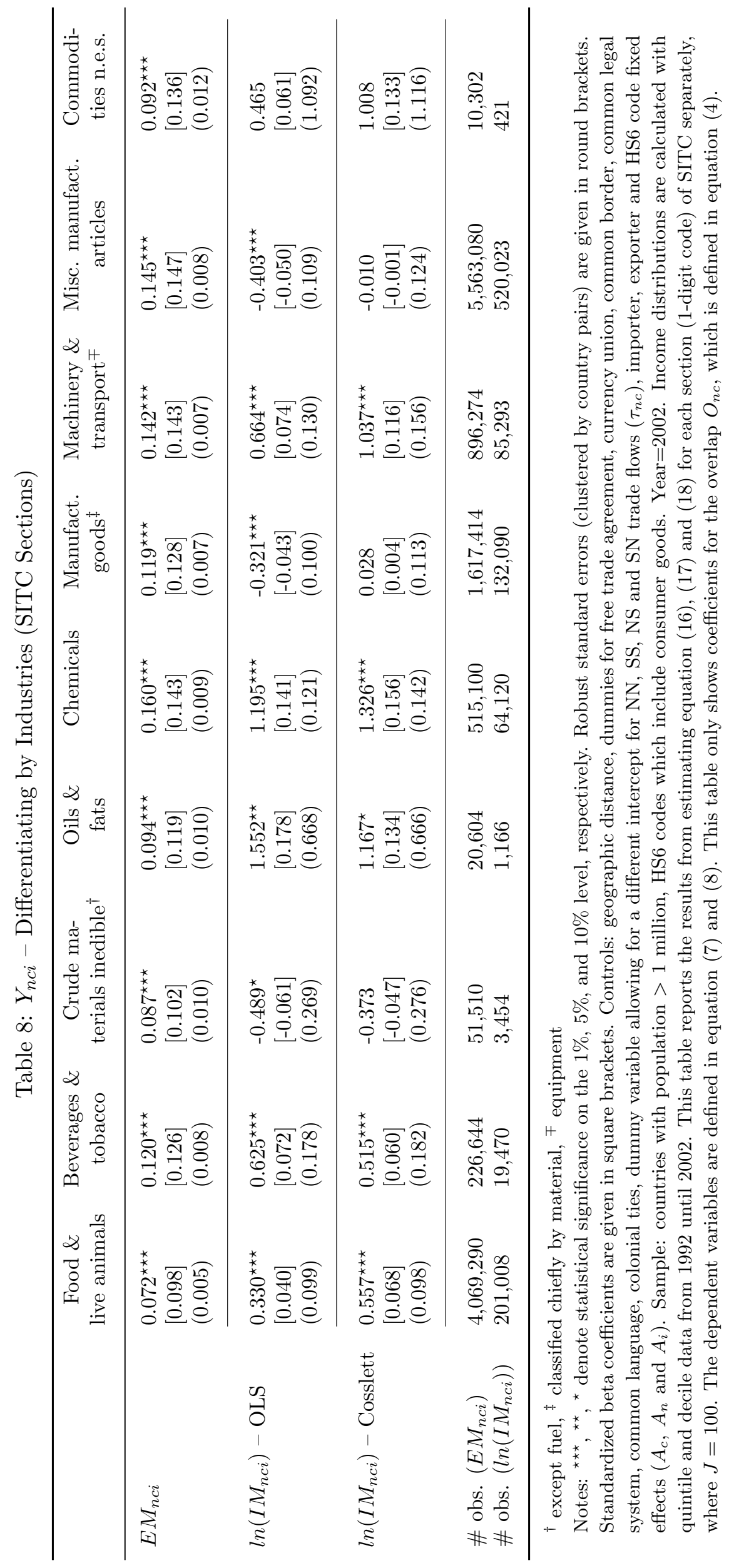


confirmative as apparel belongs to this industry. Note that on the 4-digit level the relation between income similarity and trade in manufactured goods is significantly positive.

\section{Conclusion}

This paper investigates empirically how similarity of demand structures - approximated by similarity of income distributions - affects trade patterns along the extensive and intensive margin. The idea that similarity of demand structures intensifies trade has a long tradition in the economic literature, originally put forth by Linder (1961), and more recently by Markusen (1986) or Foellmi et al. (2010).

The three main findings of this paper provide comprehensive and consistent evidence that similarity of demand structures is an important determinant of bilateral trade margins. First, the more similar two countries are regarding their income distributions, the higher is their bilateral trade volume in consumer goods. This effect is driven by both margins. The magnitudes of the effects are economically relevant. On average, countries with a one standard deviation higher overlap have a $35 \%$ higher trade value, trade a $22 \%$ more diversified bundle of goods (extensive margin) and trade $13 \%$ more within a given set of goods (intensive margin). Second, the two novel measures characterizing the overlap area are also positively related to both trade margins. I find that not only the extent to which two income distributions overlap but also at which income levels the overlap is concentrated matters for trade. Moreover, measuring income similarity with the width of the overlap area implies too that bilateral trade margins increase in similarity of demand patterns. Third, also both margins of disaggregate trade flows increase in similarity of income distributions. I document that both the probability that two countries trade a given product (extensive margin) and the trade value within a given category (intensive margin) increase in income similarity. Thus, both aggregate as well as disaggregate trade flows increase along both margins in income distribution similarity.

I make two major contributions. First, I decompose the effect of income similarity on trade values into an effect on the extensive and intensive margin. Second, in this paper the relationship between similarity of income distributions - as opposed to similarity of average incomes - and bilateral trade flows is analyzed. Furthermore, I make two methodological contributions by establishing two novel measures for similarity of income distributions and by developing a new procedure to compute national income distributions with income shares and per capita incomes.

The present analysis could be extended in several ways. So far, the quality margin has not been taken into account. Murphy \& Shleifer (1997), Hallak (2010) or Fajgelbaum et al. (2011b) predict that countries with more similar demand structures trade more with each other as such country pairs demand and produce goods of similar quality. For the empirical analysis this implies that countries with more similar income distributions trade more - which has already been shown in this paper - and that the more similar two countries are, the more similar are the quality levels they trade. 
In addition, these models predict that countries whose income distributions overlap at higher levels of income trade goods of higher quality. Furthermore, working out a formal model based on nonhomothetic preferences in which consumption and production patterns overlap and trade emerges due to product differentiation and love for variety would be of interest. In particular, such a model would shed light on aggregation effects from the product to the aggregate level, and whether such aggregation effects differ when non-homotheticity is horizontal - i.e. horizontally differentiated goods with varying income elasticities - instead of vertical as in Hallak (2010). 


\section{References}

Atkinson, A. B. \& Brandolini, A. (2001). Promise and Pitfalls in the Use of "Secondary" Data-Sets: Income Inequality in OECD Countries as a Case Study. Journal of Economic Literature, 39(3), $771-799$.

Auer, R. (2010). Consumer Heterogeneity and the Impact of Trade Liberalization: How Representative is the Representative Agent Framework?, Swiss National Bank, Working Papers: 2010-13.

Bernasconi, C. \& Wuergler, T. (2012). Per Capita Income and the Quality and Variety of Imports, University of Zurich, Mimeo.

Bils, M. \& Klenow, P. (1998). Using Consumer Theory to Test Competing Business Cycle Models. Journal of Political Economy, 106(2), 233-261.

Bohman, H. \& Nilsson, D. (2007). Market Overlap and the Direction of Exports - A New Approach of Assessing the Linder Hypothesis, CESIS Working Paper No. 86.

Broda, C. \& Romalis, J. (2009). The Welfare Implications of Rising Price Dispersion, University of Chicago, Mimeo.

Cadot, O., Carrère, C., \& Strauss-Kahn, V. (2011). Export Diversification: What's Behind the Hump? The Review of Economics and Statistics, 93(2), 590-605.

Caron, J., Fally, T., \& Markusen, J. R. (2012). Skill Premium and Trade Puzzles: A Solution Linking Production and Preferences, CEPR Discussion Papers No. 8999.

Choi, C. (2002). Linder Hypothesis Revisited. Applied Economics Letters, 9(9), 601-605.

Choi, Y. C., Hummels, D., \& Xiang, C. (2009). Explaining Import Quality: The Role of the Income Distribution. Journal of International Economics, 78(2), 293-303.

Cosslett, S. (1983). Distribution-Free Maximum Likelihood Estimator of the Binary Choice Model. Econometrica, 51(3), 765-782.

Cosslett, S. (1991). Distribution-Free Estimator of a Regression Model with Sample Selectivity, in: W.A. Barnett, J.L. Powell and G. Tauchen, eds., Nonparametric and Semiparametric Methods in Econometrics and Statistics. Cambridge: Cambridge University Press.

Dalgin, M., Trindade, V., \& Mitra, D. (2008). Inequality, Nonhomothetic Preferences, and Trade: A Gravity Approach. Southern Economic Journal, 74(3), 747-774.

Deaton, A. (1975). The Measurement of Income and Price Elasticities. European Economic Review, $6(3), 261-273$.

Dollar, D. \& Kraay, A. (2002). Growth Is Good for the Poor. Journal of Economic Growth, 7(3), $195-225$.

Engel, E. (1857). Die Productions- und Consumptionsverhältnisse des Königreichs Sachsen. Zeitschrift des Statistischen Büreaus des Königlich Sächsischen Ministeriums des Inneren, (No. 8 and 9).

Fajgelbaum, P., Grossman, G., \& Helpman, E. (2011a). A Linder Hypothesis for Foreign Direct Investment, NBER Working Paper No. 17550.

Fajgelbaum, P., Grossman, G., \& Helpman, E. (2011b). Income Distribution, Product Quality, and International Trade. Journal of Political Economy, 119(4), 721-765.

Fieler, A. C. (2011a). Nonhomotheticity and Bilateral Trade: Evidence and a Quantitative Explanation. Econometrica, 79(4), 1069-1101.

Fieler, A. C. (2011b). Quality Differentiation in International Trade: Theory and Evidence, University of Pennsylvania, Mimeo.

Foellmi, R., Hepenstrick, C., \& Zweimueller, J. (2010). Non-homothetic Preferences, Parallel Imports and the Extensive Margin of International Trade, CEPR Discussion Paper No. 7939.

Foellmi, R., Oechslin, M., \& Zahner, M. (2011). Inequality and Growth: Relying on Quantile Shares, University of Bern, Mimeo.

Francois, J. \& Kaplan, S. (1996). Aggregate Demand Shifts, Income Distribution, and the Linder Hypothesis. The Review of Economics and Statistics, 78(2), 244-250.

Gaulier, G. \& Zignago, S. (2010). BACI: International Trade Database at the Product-level. The 
1994-2007 Version, CEPII Working Paper No. 2010-23.

Hallak, J. C. (2010). A Product-Quality View of the Linder Hypothesis. The Review of Economics and Statistics, 92(3), 453-466.

Helpman, E., Melitz, M., \& Rubinstein, Y. (2008). Estimating Trade Flows: Trading Partners and Trading Volumes. The Quarterly Journal of Economics, 123(2), 441-487.

Hepenstrick, C. (2010). Per-Capita Incomes and the Extensive Margin of Bilateral Trade, University of Zurich, Working Paper Series / Institute for Empirical Research in Economics No. 519.

Heston, A., Summers, R., \& Aten, B. (2009). Penn World Table Version 6.3, Center for International Comparisons of Production, Income and Prices at the University of Pennsylvania.

Hummels, D. \& Klenow, P. (2005). The Variety and Quality of a Nation's Exports. The American Economic Review, 95(3), 704-723.

Hunter, L. (1991). The Contribution of Nonhomothetic Preferences to Trade. Journal of International Economics, 30(4), 345-358.

Hunter, L. \& Markusen, J. (1988). Per Capita Income as a Basis for Trade, in Robert Feenstra, Empirical Methods for International Trade, Cambridge: MIT Press.

Jackson, L. F. (1984). Hierarchic Demand and the Engel Curve for Variety. The Review of Economics and Statistics, 66(1), 8-15.

Kohler, A. (2012). Trade and Growth in an Unequal Global Economy, University of Zurich, Working Paper Series / Department of Economics No. 81.

Krugman, P. (1980). Scale Economies, Product Differentiation, and the Pattern of Trade. The American Economic Review, 70(5), 950-59.

Li, N. (2012). An Engel Curve for Variety, University of Toronto, Mimeo.

Linder, S. (1961). An Essay on Trade and Transformation. Uppsala: Almqvist and Wiksells.

LIS. Luxembourg Income Study Database, http://www.lisproject.org/techdoc.htm.

Markusen, J. (1986). Explaning the Volume of Trade: An Eclectic Approach. The American Economic Review, 76(5), 1002-1011.

Markusen, J. (2010). Putting Per-Capita Income back into Trade Theory, NBER Working Paper No. 15903.

Martinez-Zarzoso, I. \& Vollmer, S. (2010). Bilateral Trade Flows and Income-Distribution Similarity, Working Papers on International Economics and Finance.

Matsuyama, K. (2000). A Ricardian Model with a Continuum of Goods under Non-homothetic Preferences: Demand Complementarities, Income Distribution, and North-South Trade. Journal of Political Economy, 108(6), 1093-1120.

McPherson, M. A., Redfearn, M. R., \& Tieslau, M. A. (2000). A Re-Examination of The Linder Hypothesis: A Random-Effects Tobit Approach. International Economic Journal, 14 (3), 123-136.

Melitz, M. (2003). The Impact of Trade on Intra-industry Reallocations and Aggregate Industry Productivity. Econometrica, 71, 1695-1725.

Mitra, D. \& Trindade, V. (2005). Inequality and Trade. The Canadian Journal of Economics, 38(4), $1253-1271$.

Murphy, K. \& Shleifer, A. (1997). Quality and Trade. Journal of Development Economics, 53(1), $1-15$.

Sauré, P. (2009). Bounded Love of Variety and Patterns of Trade, Swiss National Bank, Working Papers: 2009-10.

Simonovska, I. (2010). Income Differences and Prices of Tradables, NBER Working Paper No. 16233.

Thursby, J. \& Thursby, M. (1987). Bilateral Trade Flows, the Linder Hypothesis, and Exchange Risk. The Review of Economics and Statistics, 69(3), 488-495.

UNU-WIDER (2008a). World Income Inequality Database, User Guide and Data Sources.

UNU-WIDER (2008b). World Income Inequality Database, Version 2.0c, May, www.wider.unu.edu/research/Database/en_GB/database/. 


\section{Appendix - Inequality Data}

I use the income shares reported in the WIID as it is the only database about within-country inequality which covers a large number of countries. In the raw data $\tilde{s}_{a t}^{d}\left(\tilde{s}_{a t}^{q}\right)$, the income share earned by decile $d$ (quintile $q$ ) in country $a$ and year $t$, where $d \in\{1, \ldots, 10\}(q \in\{1, \ldots, 5\})$, is observed. There are mainly two issues to be considered with these data. (i) The underlying surveys differ along several dimensions, both across countries and over time (for a given country), e.g. income versus expenditure inequality. (ii) If a country is included in the WIID the corresponding income shares are usually not observed in every year. In order to create a dataset which is as comparable as possible and which covers a large number of countries I choose for each country the "best" observation within a given time span and use this observation for the whole corresponding period. This mitigates both above mentioned issues. I can choose as consistent surveys as possible (across countries) and increase data quality by picking the "best" observation out of all available observations within a time span. This addresses some of the problems of using "secondary" datasets discussed in Atkinson \& Brandolini (2001). Moreover, there are no missing country-year observations, within a time span, by assumption. The following time spans are defined: 1992-2002, 1997-2007 and 1999-2009. Using an observation for several years is a minor issue as inequality changes slowly over time. Figure AD1 shows for two exemplary countries that quintile income shares are fairly stable over a decade.

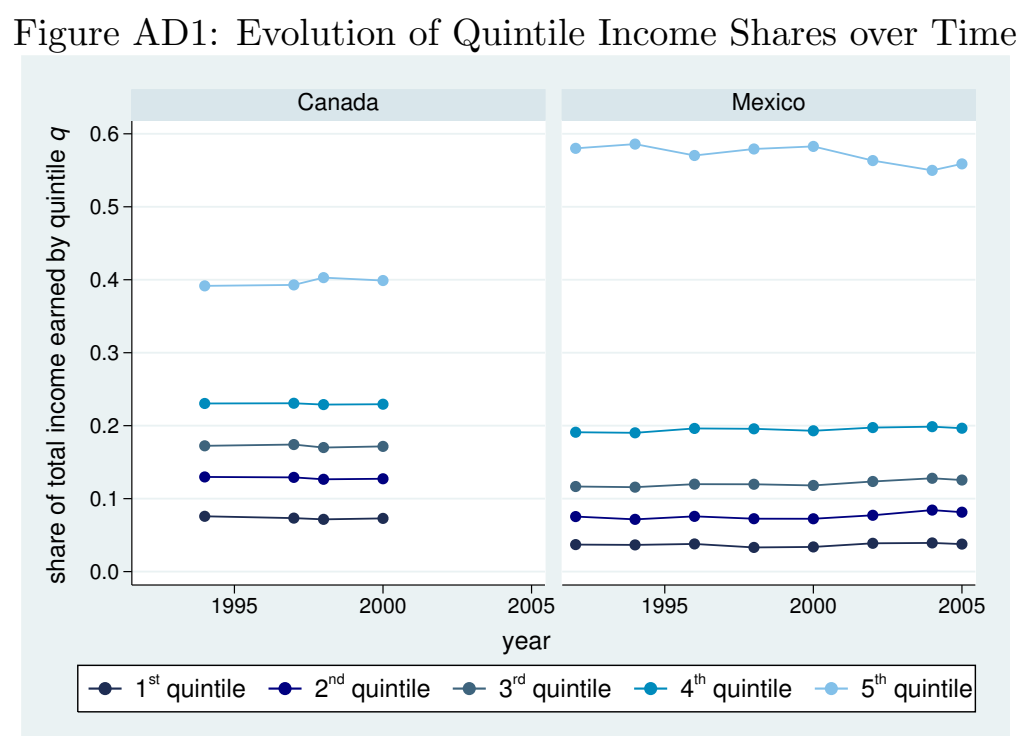

Notes: Japan cannot be used as an example as there is only one observation in the WIID from 1992-2002.

The criteria for selecting the "best" available observation about inequality for each country and time span are (i) decile shares rather than quintile shares, (ii) income inequality rather than consumption inequality, (iii) net income inequality rather than gross income inequality, (iv) high quality inequality data rather than low quality inequality data according to 4-level quality rating in WIID2c which is based on wether the underlying concepts are known and on the quality of the income concept 
and the survey (see UNU-WIDER (2008a)), (v) inequality data with full area, population and age coverage rather than inequality data with partial area, population and age coverage, (vi) inequality regarding individuals rather than inequality regarding households and (vii) inequality data adjusted to person inequality rather than unadjusted inequality data. If more than one observation, per country and time span, fulfill these criteria likewise I take the arithmetic mean (over time). The "best" observation for $a$, selected according to (i)-(vii), is denoted by $\breve{s}_{a}^{d}$ respectively $\breve{s}_{a}^{q}$ and is used for the whole time span 39

Choosing as consistent surveys as possible mitigates the problem of comparability across countries but does not resolve it completely. For example, if there is no survey based on income inequality for a country in a given time span. In order to account for the well known difference between income and consumption inequality all expenditure based inequality measures are adjusted as in Foellmi et al. (2011), which is similar to the adjustment in Dollar \& Kraay (2002). $\breve{s}_{a}^{d, b}$ denotes the share of total income (expenditure) which is earned (spent) by decile $d$ in country $a$. For $b=i n c$ the decile reflects inequality in income and for $b=\exp$ inequality in expenditure. Each expenditure based decile is multiplied by its adjustment factor $A^{d}$ which equals the ratio between the sample mean of income based deciles and the sample mean of expenditure based deciles ${ }^{40}$ The scaling factor $S_{a}^{d e c}$ ensures that the adjusted decile shares $s_{a}^{d}$ add up to 1 .

$$
s_{a}^{d}=\left\{\begin{array}{ll}
\breve{s}_{a}^{d, b} A^{d} S_{a}^{d e c} & \text { if } b=\exp \\
\breve{s}_{a}^{d, b} & \text { if } b=i n c
\end{array}, \quad A^{d}=\frac{\frac{1}{N^{d, i n c}} \sum_{a} \sum_{t} \tilde{s}_{a t}^{d, i n c}}{\frac{1}{N^{d, e x p}} \sum_{a} \sum_{t} \tilde{s}_{a t}^{d, \text { exp }}}, \quad S_{a}^{\text {dec }}=\frac{1}{\sum_{d} \breve{s}_{a}^{d, e x p} A^{d}}, \quad \sum_{d} s_{a}^{d}=1\right.
$$

Expenditure based quintiles are adjusted accordingly. As all inequality measures of rich countries are income based only observations of middle income and poor countries need to be adjusted. The adjustment factors are therefore calculated with data of middle income and poor countries only.

After choosing from all available observations $\left(\tilde{s}_{a t}^{d}\right)$ the "best" observation for each country and time span $\left(\breve{s}_{a}^{d}\right)$, and where required adjusting it from expenditure to income inequality $\left(s_{a}^{d}\right)$, I have income shares for 102 countries for the time span from 1992 to 2002. For 94 countries I have decile income shares $\left(s_{a}^{1}, \ldots, s_{a}^{10}\right)$ and for 8 countries quintile income shares $\left(s_{a}^{1}, \ldots, s_{a}^{5}\right)$. For the period 1997 to 2007 income shares are available for 91 countries (deciles for 66 and quintiles for 25 countries) and from 1999 to 2009 for 88 countries (deciles for 55 and quintiles for 33 countries).

One might find it intuitive to think of a Lorenz curve rather than income shares. The Lorenz curve is a graphical representation of the cumulative distribution function of income. $L C_{a}^{d}=\sum_{\delta=1}^{d} s_{a}^{\delta}$ is the share of total income of country $a$ earned by individuals belonging to decile $d$ or lower. Note that piecewise linear Lorenz curves, as used in this paper, underestimate inequality.

\footnotetext{
${ }^{39}$ An observation is composed of all income shares, i.e. $\left(\breve{s}_{a}^{1}, \ldots, \breve{s}_{a}^{10}\right)$ or $\left(\breve{s}_{a}^{1}, \ldots, \breve{s}_{a}^{5}\right)$.

${ }^{40} A^{1}=0.58, A^{2}=0.73, A^{3}=0.79, A^{4}=0.83, A^{5}=0.86, A^{6}=0.90, A^{7}=0.93, A^{8}=0.97, A^{9}=1.02, A^{10}=1.19$
} 


\section{Appendix - Figures}

Figure A1: A Discrete Empirical Income Distribution for a Sample of Countries
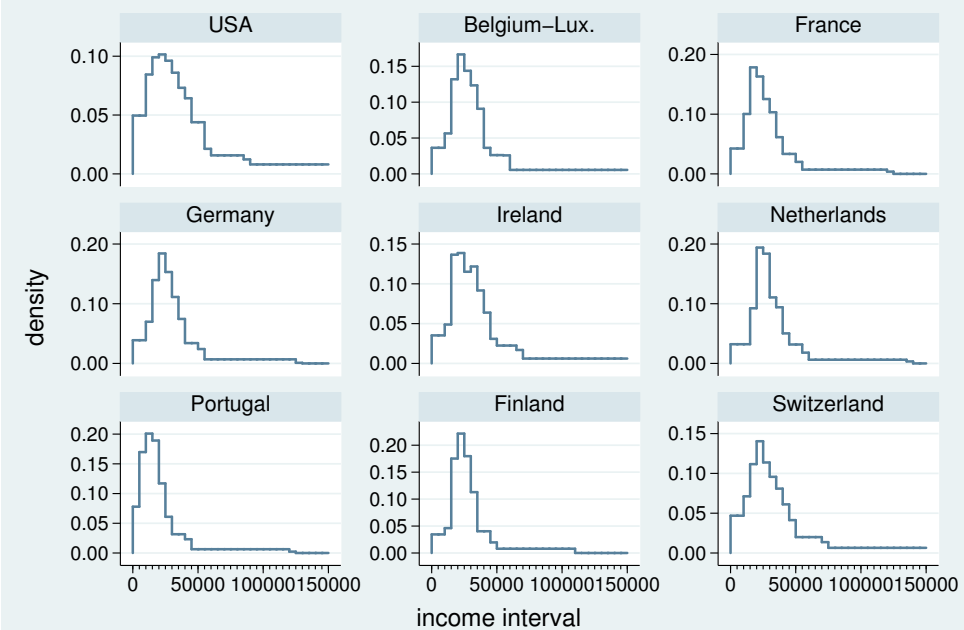

income interval
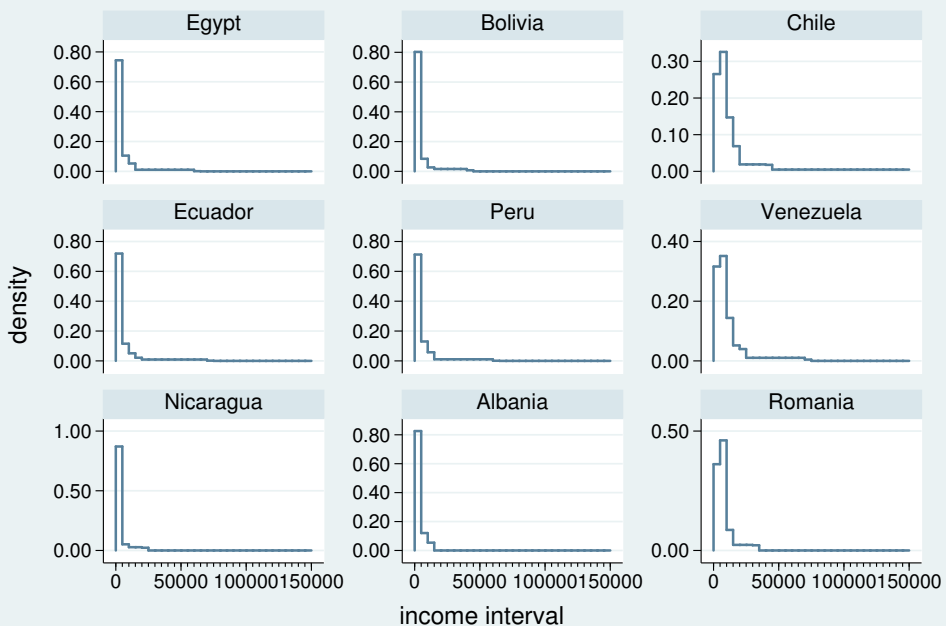

income interval
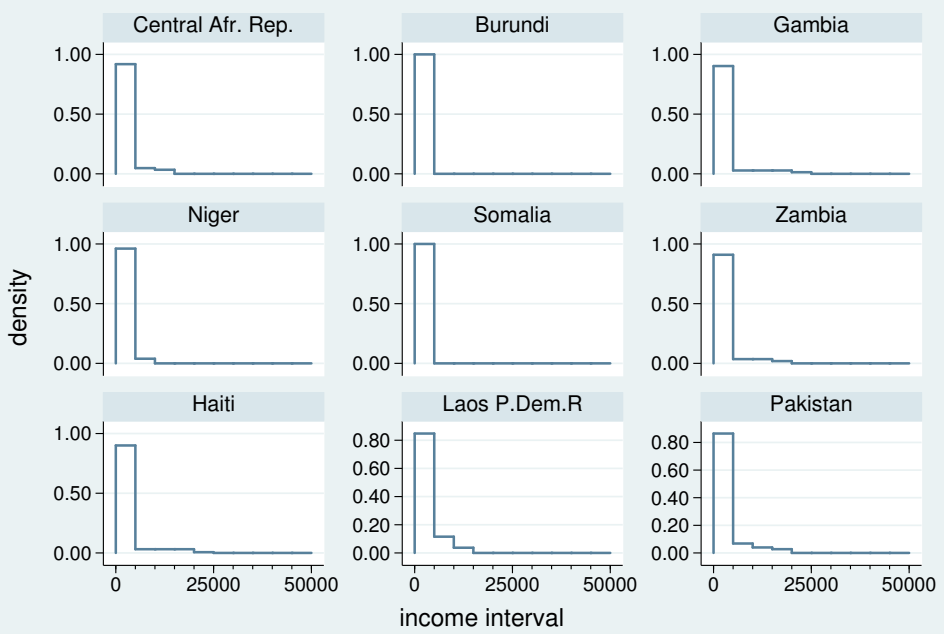

Notes: The decile (quintile) income shares $s_{a}^{d}\left(s_{a}^{q}\right)$ are for time span 1992-2002. The average income levels of deciles (quintiles) $x_{a t}^{d}\left(x_{a t}^{q}\right)$ are for $t=2002$. This is a random sample of 9 rich, 9 middle income and 9 poor countries. 
Figure A2: World Income Inequality Database (WIID) versus Luxembourg Income Study (LIS) Canada's Income Distribution with LIS (percentiles)

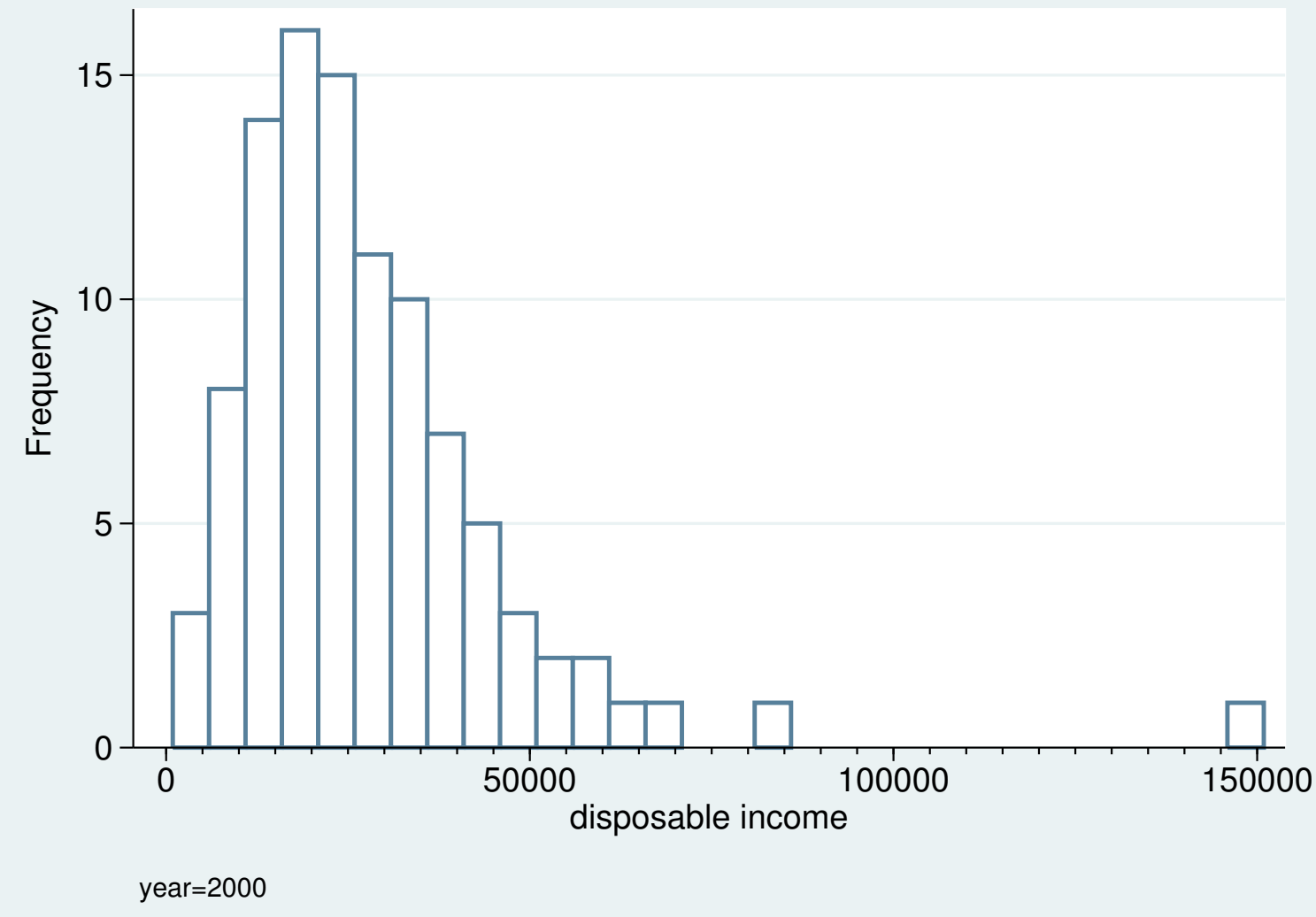

Canada's Income Distribution with WIID (deciles)

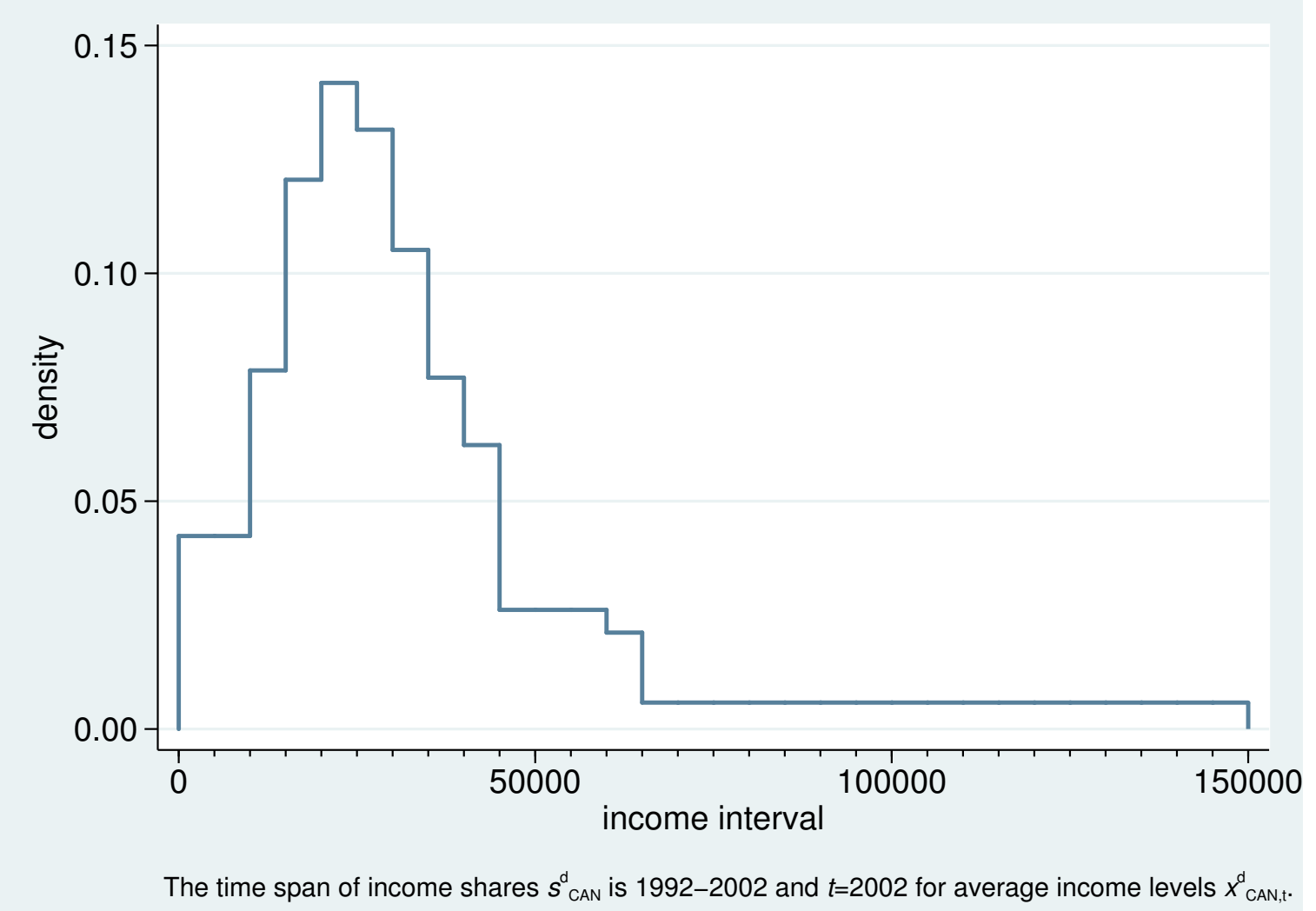


Figure A3: Overlap of Japan's and Mexico's Income Distributions

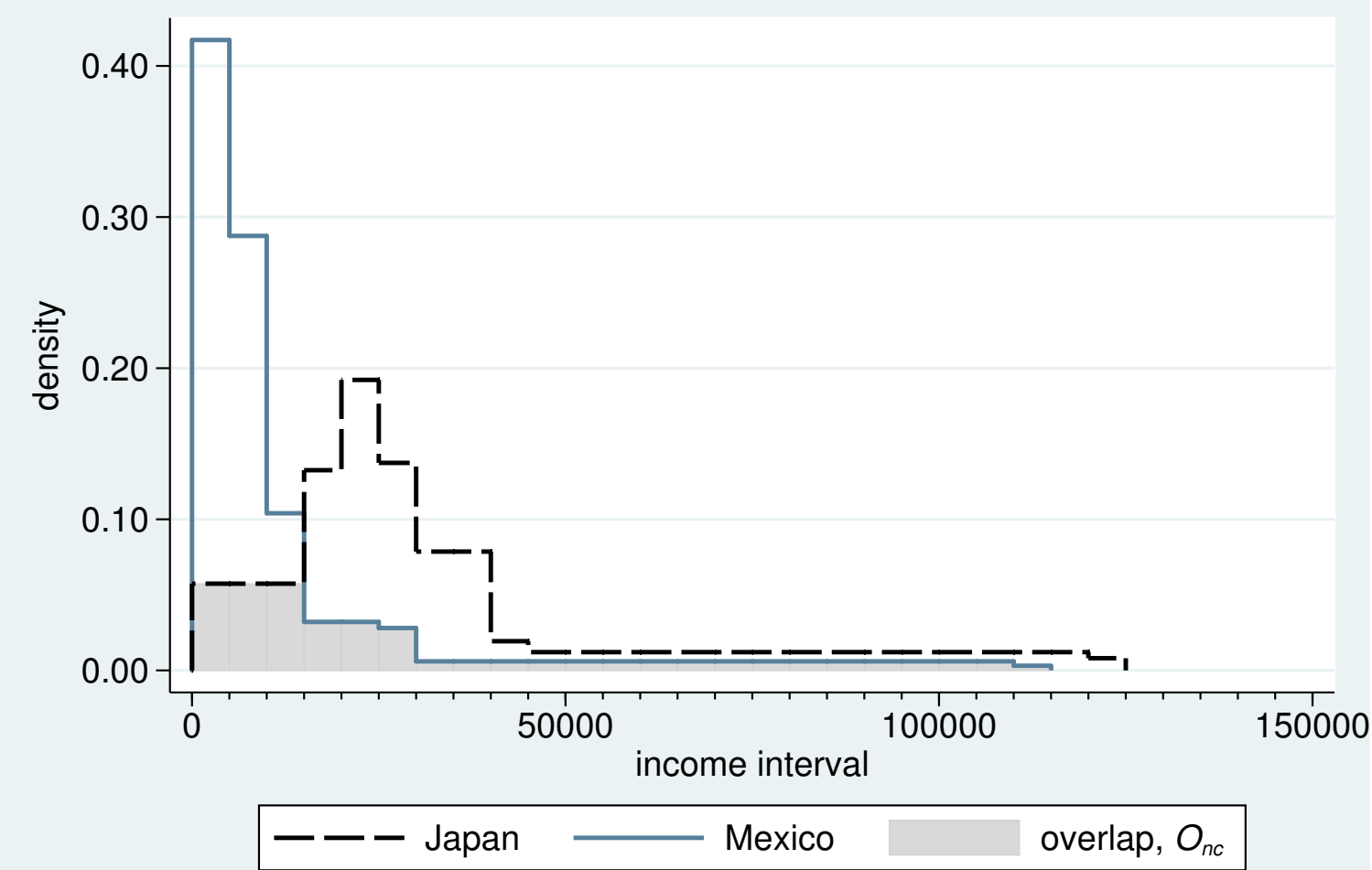

The time span of income shares $s^{d}{ }_{a}$ is $1992-2002$ and $t=2002$ for average income levels $x^{d}$ at. 
Figure A4: Histogram of Similarity Measures
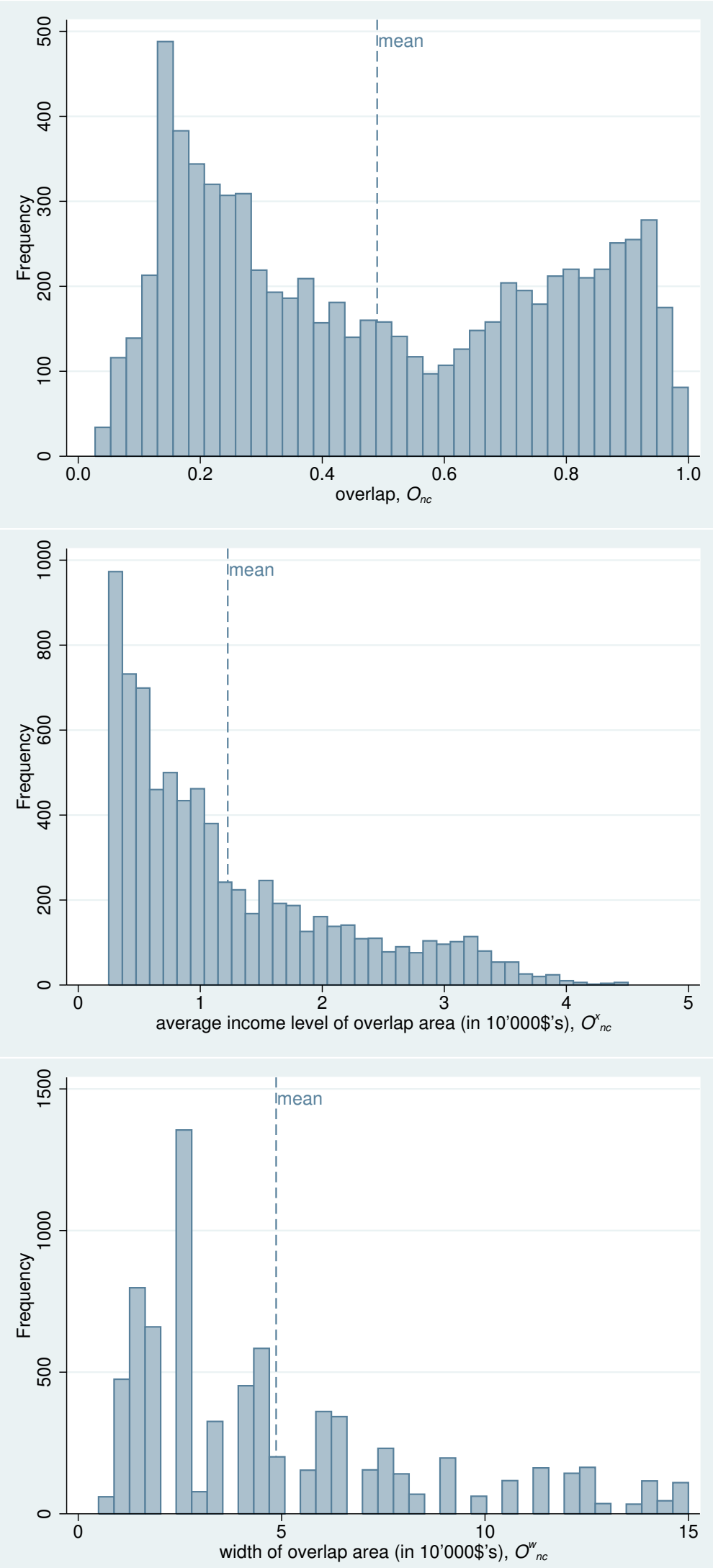

Notes: The decile (quintile) income shares $s_{a}^{d}\left(s_{a}^{q}\right)$ are for time span 1992-2002. The average income levels of deciles (quintiles) $x_{a t}^{d}\left(x_{a t}^{q}\right)$ are for $t=2002$. 
Figure A5: The Effect of Articles of Apparel when Disaggregating from HS4 to HS6 Level

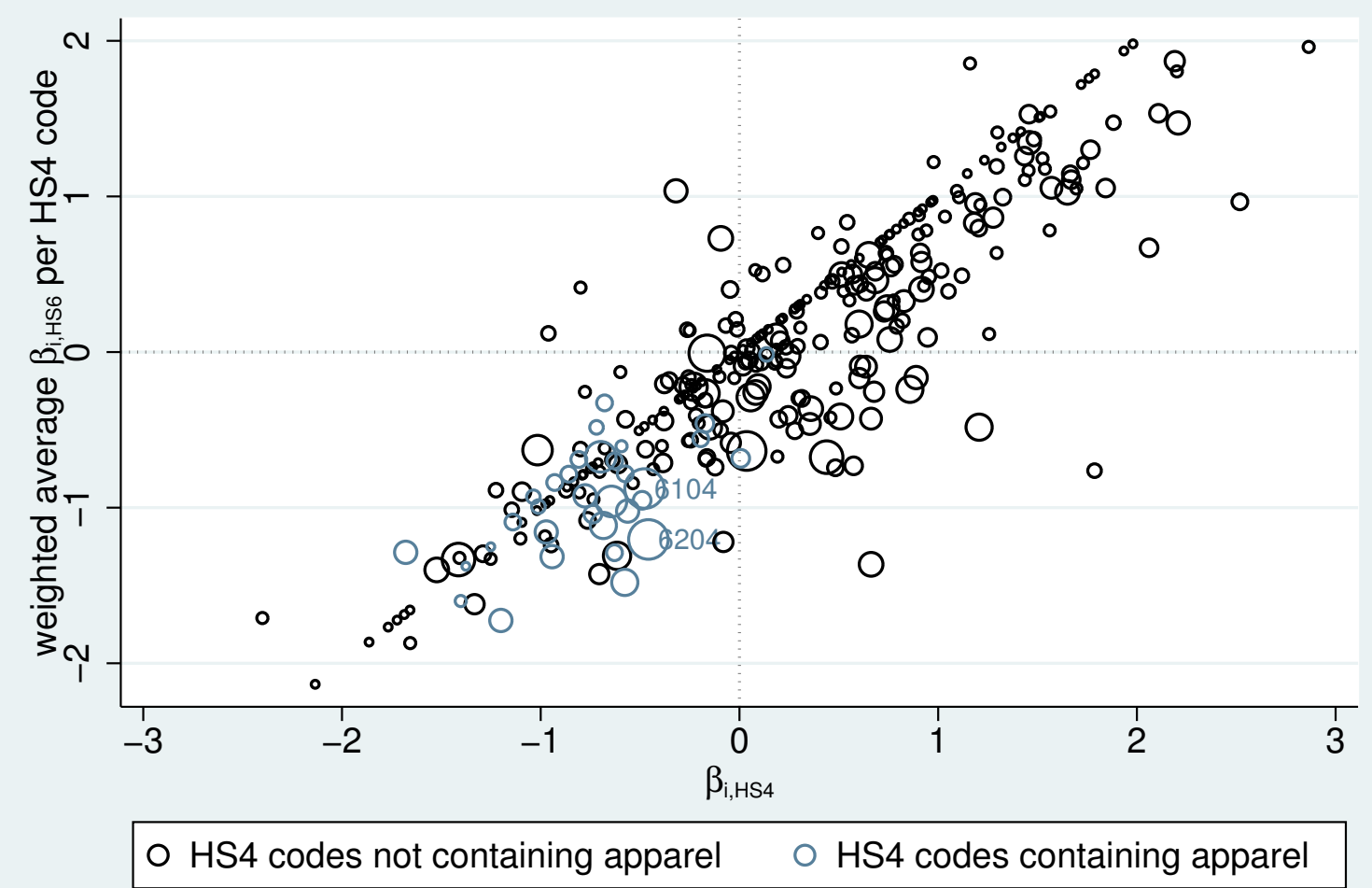

The $\beta_{i, H s 6}$ 's are weighted by the number of observations. The size of the circle represents the number of HS6 codes within a HS4 code. 4 observations are omitted in order to improve readablity. 


\section{Appendix - Tables}

Table A1: Some Examples of the 6-digit Harmonized System (HS) Classification, Version 1992

\begin{tabular}{ll}
\hline HS 6-digit code & Name \\
\hline 080130 & Cashew nuts, fresh or dried \\
081010 & Strawberries, fresh \\
091050 & Curry \\
200970 & Apple juice not fermented or spirited \\
220300 & Beer made from malt \\
220830 & Whiskies \\
220410 & Grape wines, sparkling \\
220421 & Grape wines nes, fortified wine or must, pack $<21$ \\
220429 & Grape wines, alcoholic grape must nes \\
220430 & Grape must, unfermented, except as fruit juice \\
490199 & Printed reading books, except dictionaries etc. \\
610421 & Women's, girls ensembles, of wool or hair, knit \\
610422 & Women's, girls ensembles, of cotton, knit \\
610423 & Women's, girls ensembles, synthetic fibres, knit \\
610429 & Women's, girls ensembles, of material nes, knit \\
841821 & Refrigerators, household compression type \\
842211 & Dish washing machines (domestic) \\
851650 & Microwave ovens \\
870321 & Automobiles, spark ignition engine of $<1000 \mathrm{cc}$ \\
870322 & Automobiles, spark ignition engine of $1000-1500 \mathrm{cc}$ \\
870323 & Automobiles, spark ignition engine of $1500-3000 \mathrm{cc}$ \\
870324 & Automobiles, spark ignition engine of $>3000 \mathrm{cc}$ \\
871110 & Motorcycles, spark ignition engine of $<50 \mathrm{cc}$ \\
871120 & Motorcycles, spark ignition engine of $50-250 \mathrm{cc}$ \\
871130 & Motorcycles, spark ignition engine of $250-500 \mathrm{cc}$ \\
871140 & Motorcycles, spark ignition engine of $500-800 \mathrm{cc}$ \\
871150 & Motorcycles, spark ignition engine of $>800 \mathrm{cc}$ \\
871190 & Motorcycles with other than a spark ignition engine \\
900410 & Sunglasses \\
\hline &
\end{tabular}

Notes: The HS has four hierarchical levels. The 1-digit level corresponds to sections, the 2-digit level represents chapters, the 4-digit codes identify headings and the 6-digit codes represent sub-headings. For instance, the HS4 code 8703, vehicles for transport of persons, comprises the following HS6 codes: 870310 (Snowmobiles, golf cars, similar vehicles), 870321/2/3/4 (Automobiles, spark ignition engine of $<1000 \mathrm{cc} / 1000-1500 \mathrm{cc} / 1500-3000 \mathrm{cc} />3000$ cc), $870331 / 2 / 3$ (Automobiles, diesel engine of $<1500 \mathrm{cc} / 1500-2500 \mathrm{cc} />2500$ cc), 870390 (Automobiles nes including gas turbine powered). 
Table A2: Summary Statistics

\begin{tabular}{|c|c|c|c|c|c|c|c|c|}
\hline & $\min$ & $25^{t h}$ perc. & median & mean & $75^{\text {th }}$ perc. & $\max$ & St. dev. & $\mathrm{N}$ \\
\hline$V_{n c}$ & 0.000 & 0.000 & 0.001 & 0.016 & 0.008 & 1.802 & 0.066 & $7^{\prime} 630$ \\
\hline$E M_{n c}$ & 0.000 & 0.021 & 0.138 & 0.252 & 0.409 & 1.000 & 0.277 & 7’630 \\
\hline$I M_{n c}$ & 0.000 & 0.003 & 0.013 & 0.087 & 0.041 & 44.470 & 0.897 & 7’630 \\
\hline $\ln \left(V_{n c}\right)$ & -16.977 & -9.286 & -6.854 & -7.171 & -4.791 & 0.589 & 3.106 & 7’630 \\
\hline $\ln \left(E M_{n c}\right)$ & -12.730 & -3.885 & -1.982 & -2.639 & -0.894 & -0.000 & 2.276 & 7’630 \\
\hline $\ln \left(I M_{n c}\right)$ & -12.988 & -5.769 & -4.371 & -4.532 & -3.188 & 3.795 & 2.026 & 7’630 \\
\hline$\widetilde{V}_{n c}$ & 2.000 & 187.266 & 2567.169 & $1.95 \cdot 10^{5}$ & 30133.102 & $5.55 \cdot 10^{7}$ & $1.53 \cdot 10^{6}$ & $7^{\prime} 656$ \\
\hline$\widetilde{E M}_{n c}$ & 1.000 & 5.000 & 27.000 & 134.293 & 151.000 & 1237 & 227.569 & $7^{\prime} 656$ \\
\hline$\widetilde{I M}_{n c}$ & 2.000 & 27.245 & 87.432 & 407.024 & 284.205 & 53294 & 1666.251 & $7^{\prime} 656$ \\
\hline $\ln \left(\widetilde{\widetilde{V}}_{n c}\right)$ & 0.693 & 5.233 & 7.851 & 7.792 & 10.313 & 17.832 & 3.384 & $7^{\prime} 656$ \\
\hline $\ln \left(\widetilde{E M}_{n c}\right)$ & 0.000 & 1.609 & 3.296 & 3.301 & 5.017 & 7.120 & 2.040 & $7^{\prime} 656$ \\
\hline $\ln \left(\widehat{I M}_{n c}\right)$ & 0.693 & 3.305 & 4.471 & 4.491 & 5.650 & 10.884 & 1.700 & $7^{\prime} 656$ \\
\hline$E M_{n c i}$ & 0.000 & 0.000 & 0.000 & 0.079 & 0.000 & 1.000 & 0.270 & $12^{\prime} 990^{\prime} 822$ \\
\hline$I M_{n c i}$ & 2.000 & 8.190 & 32.000 & 1454.028 & 180.677 & $2.64 \cdot 10^{7}$ & 46139.906 & 1'028'150 \\
\hline $\ln \left(I M_{n c i}\right)$ & 0.693 & 2.103 & 3.466 & 3.841 & 5.197 & 17.090 & 2.187 & 1'028'150 \\
\hline$E M_{n c i(H S 4)}$ & 0.000 & 0.000 & 0.000 & 0.136 & 0.000 & 1.000 & 0.343 & 3'224'526 \\
\hline$I M_{n c i(H S 4)}$ & 2.000 & 11.768 & 56.545 & 3398 & 385 & $3.58 \mathrm{e}+07$ & 94074 & $439^{\prime} 947$ \\
\hline $\ln \left(I M_{n c i(H S 4)}\right)$ & 0.693 & 2.465 & 4.035 & 4.381 & 5.954 & 17.394 & 2.422 & $4399^{\prime} 947$ \\
\hline$E M_{n c i(H S 2)}$ & 0.000 & 0.000 & 0.000 & 0.227 & 0.000 & 1.000 & 0.419 & 690 '234 \\
\hline$I M_{n c i(H S 2)}$ & 2.000 & 18.806 & 114.902 & 9546 & 975 & $3.77 \mathrm{e}+07$ & $1.71 \mathrm{e}+05$ & $156^{\prime} 603$ \\
\hline $\ln \left(I M_{n c i(H S 2)}\right)$ & 0.693 & 2.934 & 4.744 & 5.059 & 6.883 & 17.445 & 2.699 & $156^{\prime} 603$ \\
\hline$E M_{n c i(H S 1)}$ & 0.000 & 0.000 & 0.000 & 0.355 & 1.000 & 1.000 & 0.479 & $206^{\prime} 040$ \\
\hline$I M_{n c i(H S 1)}$ & 2.000 & 27.011 & 210.541 & 20437 & 2155 & $3.78 \mathrm{e}+07$ & $2.70 \mathrm{e}+05$ & 73’149 \\
\hline $\ln \left(I M_{n c i(H S 1)}\right)$ & 0.693 & 3.296 & 5.350 & 5.622 & 7.676 & 17.448 & 2.928 & $73 ' 149$ \\
\hline$O_{n c}$ & 0.028 & 0.224 & 0.440 & 0.490 & 0.768 & 1.000 & 0.287 & 7’630 \\
\hline$O_{n c}^{\bar{x}}$ & 0.250 & 0.500 & 0.925 & 1.225 & 1.713 & 4.505 & 0.910 & $7^{\prime} 630$ \\
\hline$O_{n c}^{w}$ & 0.500 & 2.000 & 4.000 & 4.865 & 6.500 & 15.000 & 3.629 & 7’630 \\
\hline$\frac{G D P p c_{c}}{G D P p c_{n}}$ & 0.011 & 0.119 & 0.278 & 0.361 & 0.567 & 1.000 & 0.282 & $7^{\prime} 630$ \\
\hline
\end{tabular}

Notes: Year $=2002$. The income similarity measures $O_{n c}, O_{n c}^{\bar{x}}$ and $O_{n c}^{w}$ are calculated with quintile and decile data from time span 1992 until 2002. The unit of both $O_{n c}^{w}$ and $O_{n c}^{\bar{x}}$ is 10 '000\$. 
Table A3: List of Countries and Dispersion of Similarity Measures within Countries

\begin{tabular}{|c|c|c|c|c|c|c|c|c|c|c|c|}
\hline \multirow[t]{2}{*}{ Country $^{\dagger}$} & \multirow{2}{*}{$\begin{array}{l}\text { income } \\
\text { group }\end{array}$} & \multicolumn{3}{|c|}{$O_{n c}$} & \multicolumn{3}{|c|}{$O_{n c}^{\bar{x}}$} & \multicolumn{3}{|c|}{$O_{n c}^{w}$} & \multirow[b]{2}{*}{$\mathrm{N}$} \\
\hline & & $\min$ & median & $\max$ & $\min$ & median & $\max$ & $\min$ & median & $\max$ & \\
\hline Albania & middle & 0.123 & 0.444 & 0.952 & 0.295 & 0.598 & 1.073 & 1.5 & 2.5 & 2.5 & 58 \\
\hline Algeria & middle & 0.178 & 0.699 & 0.958 & 0.289 & 0.707 & 1.871 & 1.0 & 4.5 & 4.5 & 76 \\
\hline Argentina & middle & 0.295 & 0.543 & 0.920 & 0.366 & 1.215 & 3.257 & 1.5 & 8.0 & 10.5 & 73 \\
\hline Australia & high & 0.148 & 0.381 & 0.864 & 0.423 & 1.677 & 4.505 & 1.0 & 6.5 & 15.0 & 91 \\
\hline Austria & high & 0.044 & 0.197 & 0.941 & 0.385 & 2.200 & 3.722 & 1.0 & 6.0 & 12.5 & 97 \\
\hline Bangladesh & low & 0.088 & 0.507 & 0.992 & 0.257 & 0.401 & 0.836 & 1.0 & 2.0 & 2.0 & 72 \\
\hline Belgium-Lux. & high & 0.048 & 0.229 & 0.925 & 0.374 & 2.068 & 4.036 & 1.0 & 6.0 & 15.0 & 98 \\
\hline Bolivia & middle & 0.168 & 0.530 & 0.997 & 0.299 & 0.744 & 1.839 & 1.5 & 4.5 & 4.5 & 66 \\
\hline Brazil & middle & 0.260 & 0.674 & 0.955 & 0.250 & 0.875 & 3.645 & 0.5 & 7.0 & 12.0 & 83 \\
\hline Bulgaria & middle & 0.182 & 0.511 & 0.960 & 0.250 & 0.757 & 1.890 & 0.5 & 4.5 & 4.5 & 79 \\
\hline Burkina Faso & low & 0.127 & 0.444 & 0.987 & 0.263 & 0.532 & 1.290 & 1.0 & 3.0 & 3.0 & 64 \\
\hline Burundi & low & 0.044 & 0.095 & 0.955 & 0.256 & 0.313 & 0.385 & 1.0 & 1.0 & 1.0 & 39 \\
\hline Cambodia & low & 0.142 & 0.408 & 0.997 & 0.307 & 0.581 & 1.160 & 1.5 & 2.5 & 2.5 & 56 \\
\hline Cameroon & middle & 0.148 & 0.440 & 0.972 & 0.297 & 0.711 & 1.571 & 1.5 & 3.5 & 3.5 & 56 \\
\hline Canada & high & 0.042 & 0.255 & 0.940 & 0.250 & 2.004 & 4.137 & 0.5 & 6.0 & 15.0 & 97 \\
\hline Central Afr. Rep. & low & 0.097 & 0.324 & 0.997 & 0.292 & 0.428 & 0.750 & 1.5 & 1.5 & 1.5 & 39 \\
\hline Chile & middle & 0.321 & 0.523 & 0.933 & 0.378 & 1.158 & 4.410 & 1.5 & 7.5 & 15.0 & 75 \\
\hline China & middle & 0.174 & 0.729 & 0.940 & 0.250 & 0.588 & 1.744 & 0.5 & 4.0 & 4.0 & 90 \\
\hline Colombia & middle & 0.227 & 0.702 & 0.941 & 0.259 & 0.898 & 2.951 & 1.0 & 7.5 & 9.0 & 79 \\
\hline Costa Rica & middle & 0.272 & 0.547 & 0.931 & 0.375 & 1.129 & 2.954 & 1.5 & 8.0 & 9.0 & 71 \\
\hline Cote D'Ivoire & low & 0.132 & 0.555 & 0.994 & 0.282 & 0.502 & 1.195 & 1.0 & 2.5 & 2.5 & 75 \\
\hline Denmark & high & 0.069 & 0.221 & 0.941 & 0.500 & 2.158 & 3.652 & 1.0 & 6.0 & 12.0 & 93 \\
\hline Dominican Rp & middle & 0.244 & 0.647 & 0.909 & 0.326 & 1.103 & 2.783 & 1.5 & 8.0 & 8.0 & 63 \\
\hline Ecuador & middle & 0.198 & 0.600 & 0.964 & 0.283 & 0.932 & 2.653 & 1.0 & 7.5 & 7.5 & 69 \\
\hline Egypt & niddle & 0.181 & 0.801 & 0.990 & 0.282 & 0.694 & 2.391 & 1.0 & 6.0 & 6.5 & 81 \\
\hline El Salvador & middle & 0.183 & 0.643 & 0.959 & 0.350 & 0.872 & 2.213 & 2.0 & 5.5 & 5.5 & 62 \\
\hline Ethiopia & low & 0.064 & 0.482 & 0.995 & 0.274 & 0.332 & 0.605 & 1.0 & 1.5 & 1.5 & 69 \\
\hline Finland & high & 0.069 & 0.236 & 0.944 & 0.500 & 2.100 & 3.421 & 1.0 & 6.5 & 11.5 & 90 \\
\hline Fm Czechoslovakia & high & 0.073 & 0.342 & 0.901 & 0.332 & 1.520 & 2.514 & 1.0 & 6.0 & 6.5 & 93 \\
\hline Fm Ussr & middle & 0.208 & 0.481 & 0.953 & 0.250 & 0.813 & 2.044 & 0.5 & 5.0 & 5.0 & 95 \\
\hline Fm Yugoslavia & middle & 0.142 & 0.326 & 0.857 & 0.250 & 0.955 & 1.814 & 0.5 & 4.0 & 4.0 & 97 \\
\hline France & high & 0.042 & 0.247 & 0.948 & 0.250 & 1.870 & 3.687 & 0.5 & 5.5 & 12.5 & 101 \\
\hline Gambia & low & 0.125 & 0.449 & 0.996 & 0.265 & 0.490 & 1.137 & 1.0 & 2.5 & 2.5 & 58 \\
\hline Germany & high & 0.039 & 0.240 & 0.922 & 0.250 & 1.918 & 3.742 & 0.5 & 5.5 & 13.0 & 101 \\
\hline Ghana & low & 0.083 & 0.648 & 0.994 & 0.250 & 0.348 & 0.767 & 0.5 & 1.5 & 1.5 & 82 \\
\hline Greece & high & 0.084 & 0.362 & 0.925 & 0.321 & 1.556 & 3.450 & 1.0 & 6.2 & 11.5 & 90 \\
\hline Guatemala & middle & 0.205 & 0.674 & 0.963 & 0.325 & 0.920 & 2.606 & 1.5 & 7.0 & 7.0 & 70 \\
\hline Guinea & low & 0.189 & 0.607 & 0.969 & 0.250 & 0.690 & 2.024 & 0.5 & 5.5 & 5.5 & 71 \\
\hline Guinea-Bissau & low & 0.127 & 0.401 & 0.992 & 0.257 & 0.564 & 1.154 & 1.0 & 2.5 & 2.5 & 52 \\
\hline Haiti & low & 0.132 & 0.408 & 0.962 & 0.299 & 0.511 & 1.055 & 1.5 & 2.5 & 2.5 & 56 \\
\hline Honduras & middle & 0.151 & 0.594 & 0.969 & 0.283 & 0.599 & 1.565 & 1.0 & 3.5 & 3.5 & 73 \\
\hline Hong Kong & high & 0.083 & 0.372 & 0.883 & 0.250 & 1.543 & 4.372 & 0.5 & 6.0 & 15.0 & 94 \\
\hline Hungary & high & 0.072 & 0.423 & 0.901 & 0.250 & 1.362 & 2.378 & 0.5 & 6.0 & 6.0 & 82 \\
\hline India & middle & 0.137 & 0.758 & 0.989 & 0.250 & 0.427 & 1.234 & 0.5 & 2.5 & 2.5 & 91 \\
\hline Indonesia & middle & 0.165 & 0.797 & 0.953 & 0.286 & 0.562 & 1.633 & 1.0 & 4.0 & 4.0 & 87 \\
\hline Iran & middle & 0.274 & 0.538 & 0.878 & 0.305 & 1.027 & 3.092 & 1.0 & 7.0 & 7.0 & 61 \\
\hline Ireland & high & 0.047 & 0.234 & 0.929 & 0.377 & 2.138 & 4.204 & 1.0 & 6.0 & 15.0 & 95 \\
\hline Israel & high & 0.129 & 0.412 & 0.954 & 0.472 & 1.561 & 3.571 & 1.0 & 6.5 & 12.0 & 83 \\
\hline Italy & high & 0.053 & 0.275 & 0.951 & 0.250 & 1.777 & 3.919 & 0.5 & 5.8 & 14.5 & 100 \\
\hline Jamaica & middle & 0.252 & 0.676 & 0.950 & 0.313 & 1.048 & 3.283 & 1.5 & 8.5 & 10.5 & 69 \\
\hline Japan & high & 0.057 & 0.271 & 0.882 & 0.250 & 1.826 & 3.798 & 0.5 & 6.0 & 12.5 & 98 \\
\hline
\end{tabular}

$\dagger$ I report summary statistics of the dispersion of income similarity for each importer. As similarity is symmetric and as the vast majority of aggregate trade flows is two-way (88\%) a corresponding table for exporters looks very similar. 
[Table A3 continued]

\begin{tabular}{|c|c|c|c|c|c|c|c|c|c|c|c|}
\hline \multirow[t]{2}{*}{ Country } & \multirow{2}{*}{$\begin{array}{l}\text { income } \\
\text { group }\end{array}$} & \multicolumn{3}{|c|}{$O_{n c}$} & \multicolumn{3}{|c|}{$O_{n c}^{\bar{x}}$} & \multicolumn{3}{|c|}{$O_{n c}^{w}$} & \multirow[b]{2}{*}{$\mathrm{N}$} \\
\hline & & $\min$ & median & $\max$ & $\min$ & median & $\max$ & $\min$ & median & $\max$ & \\
\hline Jordan & middle & 0.175 & 0.627 & 0.956 & 0.250 & 0.772 & 1.962 & 0.5 & 5.0 & 5.0 & 71 \\
\hline Kenya & low & 0.127 & 0.696 & 0.990 & 0.250 & 0.434 & 1.146 & 0.5 & 2.5 & 2.5 & 79 \\
\hline Korea Rp (South) & high & 0.098 & 0.372 & 0.925 & 0.311 & 1.468 & 3.188 & 1.0 & 6.0 & 10.0 & 94 \\
\hline Laos P.Dem.R & low & 0.083 & 0.229 & 0.946 & 0.307 & 0.668 & 0.769 & 1.5 & 1.5 & 1.5 & 30 \\
\hline Madagascar & low & 0.069 & 0.420 & 0.984 & 0.276 & 0.353 & 0.648 & 1.0 & 1.5 & 1.5 & 63 \\
\hline Malawi & low & 0.061 & 0.496 & 0.940 & 0.275 & 0.383 & 0.581 & 1.0 & 1.5 & 1.5 & 56 \\
\hline Malaysia & middle & 0.294 & 0.494 & 0.933 & 0.337 & 1.078 & 4.163 & 1.0 & 6.5 & 15.0 & 83 \\
\hline Mali & low & 0.125 & 0.584 & 0.996 & 0.264 & 0.440 & 1.163 & 1.0 & 2.5 & 2.5 & 66 \\
\hline Mauritania & low & 0.155 & 0.456 & 0.955 & 0.280 & 0.680 & 1.566 & 1.0 & 4.0 & 4.0 & 58 \\
\hline Mexico & middle & 0.274 & 0.555 & 0.920 & 0.310 & 0.956 & 3.551 & 1.0 & 6.5 & 11.5 & 85 \\
\hline Mongolia & middle & 0.097 & 0.177 & 0.917 & 0.296 & 0.655 & 0.794 & 1.5 & 1.5 & 1.5 & 39 \\
\hline Morocco & middle & 0.176 & 0.716 & 0.950 & 0.284 & 0.692 & 1.886 & 1.0 & 4.5 & 4.5 & 73 \\
\hline Mozambique & low & 0.092 & 0.504 & 0.992 & 0.257 & 0.403 & 0.858 & 1.0 & 2.0 & 2.0 & 62 \\
\hline Nepal & low & 0.129 & 0.185 & 0.972 & 0.312 & 0.806 & 1.004 & 2.0 & 2.0 & 2.0 & 36 \\
\hline Netherlands & high & 0.032 & 0.195 & 0.933 & 0.250 & 2.113 & 3.996 & 0.5 & 5.5 & 14.0 & 101 \\
\hline New Zealand & high & 0.138 & 0.415 & 0.922 & 0.459 & 1.651 & 3.901 & 1.0 & 7.0 & 14.0 & 81 \\
\hline Nicaragua & middle & 0.133 & 0.486 & 0.997 & 0.308 & 0.526 & 1.213 & 1.5 & 2.5 & 2.5 & 69 \\
\hline Niger & low & 0.055 & 0.424 & 1.000 & 0.263 & 0.318 & 0.512 & 1.0 & 1.0 & 1.0 & 62 \\
\hline Nigeria & low & 0.113 & 0.670 & 0.998 & 0.250 & 0.394 & 1.012 & 0.5 & 2.0 & 2.0 & 89 \\
\hline Norway & high & 0.055 & 0.205 & 0.781 & 0.500 & 2.399 & 4.505 & 1.0 & 6.5 & 15.0 & 91 \\
\hline Pakistan & low & 0.136 & 0.472 & 0.989 & 0.282 & 0.583 & 1.227 & 1.0 & 2.5 & 2.5 & 63 \\
\hline Panama & middle & 0.236 & 0.680 & 0.961 & 0.295 & 0.950 & 2.814 & 1.0 & 8.0 & 8.5 & 73 \\
\hline Papua N.Guinea & low & 0.167 & 0.510 & 0.946 & 0.283 & 0.555 & 1.209 & 1.0 & 2.5 & 2.5 & 54 \\
\hline Paraguay & middle & 0.181 & 0.489 & 0.990 & 0.341 & 0.963 & 2.292 & 2.0 & 6.0 & 6.0 & 56 \\
\hline Peru & middle & 0.182 & 0.675 & 0.969 & 0.300 & 0.790 & 2.399 & 1.5 & 6.5 & 6.5 & 75 \\
\hline Philippines & middle & 0.167 & 0.640 & 0.969 & 0.283 & 0.618 & 1.864 & 1.0 & 4.5 & 4.5 & 78 \\
\hline Poland & iiddle & 0.151 & 0.396 & 0.857 & 0.250 & 1.158 & 2.432 & 0.5 & 6.5 & 6.5 & 81 \\
\hline Portugal & high & 0.129 & 0.432 & 0.954 & 0.448 & 1.520 & 3.616 & 1.0 & 6.5 & 12.5 & 89 \\
\hline Romania & middle & 0.175 & 0.511 & 0.960 & 0.319 & 0.720 & 1.662 & 1.0 & 3.5 & 3.5 & 77 \\
\hline Rwanda & low & 0.055 & 0.531 & 0.939 & 0.257 & 0.365 & 0.583 & 1.0 & 1.0 & 1.0 & 56 \\
\hline Senegal & low & 0.110 & 0.516 & 0.998 & 0.269 & 0.418 & 0.998 & 1.0 & 2.0 & 2.0 & 75 \\
\hline Somalia & low & 0.028 & 0.078 & 0.917 & 0.250 & 0.250 & 0.250 & 0.5 & 0.5 & 0.5 & 33 \\
\hline South Africa & middle & 0.243 & 0.706 & 0.925 & 0.250 & 0.662 & 4.121 & 0.5 & 6.0 & 14.0 & 95 \\
\hline Spain & high & 0.053 & 0.278 & 0.938 & 0.250 & 1.800 & 3.851 & 0.5 & 6.0 & 14.0 & 98 \\
\hline Sri Lanka & middle & 0.185 & 0.487 & 0.925 & 0.278 & 0.969 & 2.881 & 1.0 & 8.0 & 8.0 & 63 \\
\hline Sweden & high & 0.036 & 0.236 & 0.944 & 0.250 & 2.032 & 3.855 & 0.5 & 6.2 & 13.5 & 92 \\
\hline Switzerland & high & 0.094 & 0.262 & 0.940 & 0.500 & 1.962 & 4.306 & 1.0 & 6.0 & 15.0 & 96 \\
\hline Thailand & middle & 0.249 & 0.669 & 0.961 & 0.250 & 0.832 & 2.941 & 0.5 & 6.5 & 9.0 & 87 \\
\hline Trinidad-Tobago & high & 0.268 & 0.522 & 0.915 & 0.357 & 1.238 & 4.018 & 1.0 & 7.5 & 14.5 & 75 \\
\hline Tunisia & middle & 0.278 & 0.553 & 0.954 & 0.306 & 0.883 & 2.785 & 1.0 & 6.0 & 6.0 & 75 \\
\hline Turkey & middle & 0.199 & 0.707 & 0.955 & 0.293 & 0.763 & 2.357 & 1.0 & 6.0 & 6.0 & 81 \\
\hline USA & high & 0.050 & 0.265 & 0.905 & 0.250 & 1.790 & 4.428 & 0.5 & 5.5 & 15.0 & 101 \\
\hline Uganda & low & 0.083 & 0.475 & 0.994 & 0.256 & 0.371 & 0.750 & 1.0 & 1.5 & 1.5 & 64 \\
\hline United Kingdom & high & 0.046 & 0.253 & 0.951 & 0.250 & 1.832 & 3.962 & 0.5 & 5.5 & 15.0 & 101 \\
\hline Untd Rp Tanzania & low & 0.055 & 0.617 & 1.000 & 0.250 & 0.297 & 0.510 & 0.5 & 1.0 & 1.0 & 72 \\
\hline Uruguay & middle & 0.259 & 0.539 & 0.967 & 0.353 & 1.069 & 2.624 & 1.5 & 7.5 & 7.5 & 68 \\
\hline Venezuela & middle & 0.264 & 0.519 & 0.967 & 0.327 & 1.091 & 2.654 & 1.0 & 7.5 & 7.5 & 75 \\
\hline Vietnam & low & 0.130 & 0.381 & 0.994 & 0.312 & 0.638 & 1.170 & 1.5 & 2.5 & 2.5 & 58 \\
\hline Yemen & low & 0.055 & 0.248 & 0.994 & 0.275 & 0.357 & 0.500 & 1.0 & 1.0 & 1.0 & 54 \\
\hline Zambia & low & 0.102 & 0.443 & 0.992 & 0.269 & 0.435 & 0.936 & 1.0 & 2.0 & 2.0 & 62 \\
\hline Zimbabwe & low & 0.151 & 0.493 & 0.947 & 0.282 & 0.787 & 1.882 & 1.0 & 4.5 & 4.5 & 55 \\
\hline
\end{tabular}

Notes: Income classes are according to World Bank List of Economies July 2008 (http://go.worldbank.org/D7SN0B8YU0).

Economies are grouped according to 2007 GNI per capita (calculated using the World Bank Atlas method). low income: $\$ 1$ - \$935, middle income: $\$ 936$ - $\$ 11,455$, high income: $\$ 11,456$ or more. The unit of both $O_{n c}^{\bar{x}}$ and $O_{n c}^{w}$ is $10 ’ 000 \$$. 
Table A4: Summary Statistics of Similarity Measures by NN, SS and NS Country Pairs

\begin{tabular}{|c|c|c|c|c|c|c|c|c|}
\hline & $\min$ & $25^{\text {th }}$ perc. & median & mean & $75^{\text {th }}$ perc. & $\max$ & St. dev. & $\mathrm{N}$ \\
\hline \multicolumn{9}{|l|}{ overlap, $O_{n c}$} \\
\hline North-North & 0.297 & 0.642 & 0.750 & 0.724 & 0.834 & 0.954 & 0.143 & 699 \\
\hline South-South & 0.142 & 0.576 & 0.766 & 0.723 & 0.888 & 1.000 & 0.195 & 3'196 \\
\hline North-South & 0.028 & 0.152 & 0.221 & 0.247 & 0.315 & 0.915 & 0.127 & 3’735 \\
\hline all observations & 0.028 & 0.224 & 0.440 & 0.490 & 0.768 & 1.000 & 0.287 & $7^{\prime} 630$ \\
\hline \multicolumn{9}{|c|}{$\begin{array}{l}\text { average income of } \\
\text { overlap area, } O_{n c}^{\bar{x}}\end{array}$} \\
\hline North-North & 1.452 & 2.664 & 3.062 & 2.971 & 3.309 & 4.505 & 0.576 & 699 \\
\hline South-South & 0.250 & 0.347 & 0.477 & 0.560 & 0.728 & 1.967 & 0.269 & 3'196 \\
\hline North-South & 0.250 & 0.901 & 1.334 & 1.468 & 1.954 & 4.410 & 0.747 & 3'735 \\
\hline all observations & 0.250 & 0.500 & 0.925 & 1.225 & 1.713 & 4.505 & 0.910 & $7^{\prime} 630$ \\
\hline \multicolumn{9}{|c|}{$\begin{array}{l}\text { width of overlap area, } \\
O_{n c}^{w}\end{array}$} \\
\hline North-North & 6.000 & 11.500 & 12.500 & 11.829 & 14.000 & 15.000 & 2.626 & 699 \\
\hline South-South & 0.500 & 2.000 & 2.500 & 3.429 & 4.500 & 15.000 & 2.172 & 3'196 \\
\hline North-South & 0.500 & 2.500 & 4.000 & 4.790 & 6.500 & 15.000 & 3.276 & 3’735 \\
\hline all observations & 0.500 & 2.000 & 4.000 & 4.865 & 6.500 & 15.000 & 3.629 & $7^{\prime} 630$ \\
\hline
\end{tabular}

Notes: A country belongs to the "North" if it is classified as a high income country by the World Bank. Middle and low income countries appertain to the "South", see table A3 The unit of both $O_{n c}^{\bar{x}}$ and $O_{n c}^{w}$ is 10 '000\$.

Table A5: Summary Statistics of Bilateral Trade Margins by NN, SS and NS Country Pairs

\begin{tabular}{|c|c|c|c|c|c|c|c|c|}
\hline & $\min$ & $25^{t h}$ perc. & median & mean & $75^{t h}$ perc. & $\max$ & St. dev. & $\mathrm{N}$ \\
\hline \multicolumn{9}{|l|}{$\ln \left(V_{n c}\right)$} \\
\hline North-North & -15.134 & -5.874 & -4.668 & -4.807 & -3.338 & 0.229 & 2.130 & 699 \\
\hline South-South & -16.243 & -9.967 & -7.796 & -7.772 & -5.574 & 0.589 & 2.950 & 3,196 \\
\hline North-South & -16.977 & -9.092 & -6.582 & -7.099 & -4.699 & 0.580 & 3.172 & 3,735 \\
\hline all observations & -16.977 & -9.286 & -6.854 & -7.171 & -4.791 & 0.589 & 3.106 & 7,630 \\
\hline \multicolumn{9}{|l|}{$\ln \left(E M_{n c}\right)$} \\
\hline North-North & -9.513 & -0.717 & -0.326 & -0.589 & -0.106 & -0.000 & 0.920 & 699 \\
\hline South-South & -12.730 & -4.988 & -2.873 & -3.497 & -1.637 & -0.019 & 2.438 & 3,196 \\
\hline North-South & -11.803 & -3.247 & -1.690 & -2.289 & -0.855 & -0.001 & 1.948 & 3,735 \\
\hline all observations & -12.730 & -3.885 & -1.982 & -2.639 & -0.894 & -0.000 & 2.276 & 7,630 \\
\hline \multicolumn{9}{|l|}{$\ln \left(I M_{n c}\right)$} \\
\hline North-North & -10.572 & -5.084 & -4.168 & -4.218 & -3.161 & 0.229 & 1.522 & 699 \\
\hline South-South & -11.510 & -5.553 & -4.194 & -4.275 & -2.924 & 3.605 & 2.038 & 3,196 \\
\hline North-South & -12.988 & -6.077 & -4.581 & -4.810 & -3.383 & 3.795 & 2.060 & 3,735 \\
\hline all observations & -12.988 & -5.769 & -4.371 & -4.532 & -3.188 & 3.795 & 2.026 & 7,630 \\
\hline
\end{tabular}

Notes: A country belongs to the "North" if it is classified as a high income country by the World Bank. Middle and low income countries appertain to the "South", see table A3 


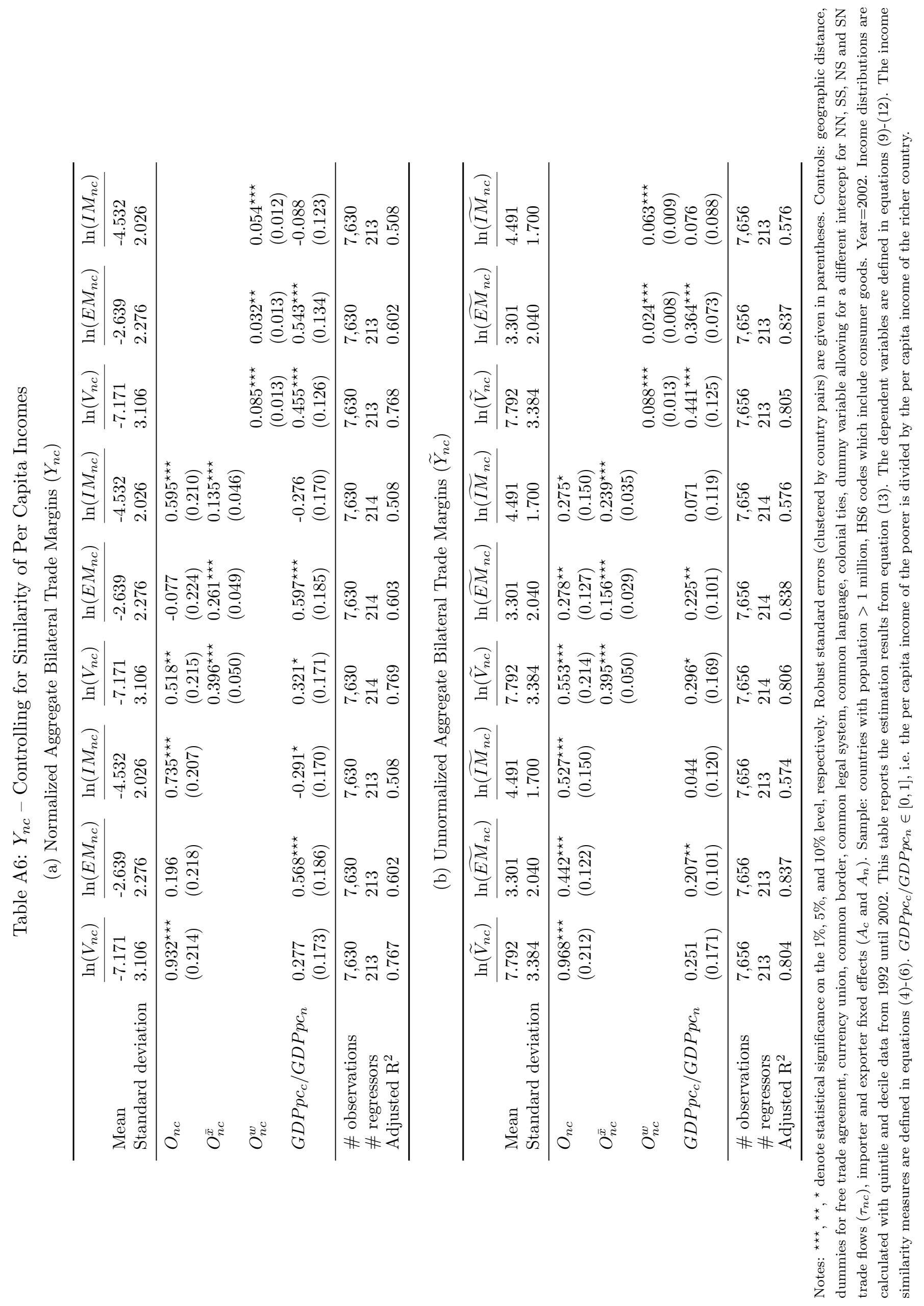


Table A7: $Y_{n c}-$ All Years

(a) $O_{n c}$, calculated with quintile and decile data from time span

\begin{tabular}{|c|c|c|c|c|c|c|c|c|c|}
\hline \multirow[b]{2}{*}{ year } & \multicolumn{3}{|c|}{1992 to 2002 (102 countries) } & \multicolumn{3}{|c|}{1997 to 2007 (91 countries) } & \multicolumn{3}{|c|}{1999 to 2009 (88 countries) } \\
\hline & $\ln \left(V_{n c}\right)$ & $\ln \left(E M_{n c}\right)$ & $\ln \left(I M_{n c}\right)$ & $\ln \left(V_{n c}\right)$ & $\ln \left(E M_{n c}\right)$ & $\ln \left(I M_{n c}\right)$ & $\ln \left(V_{n c}\right)$ & $\ln \left(E M_{n c}\right)$ & $\ln \left(I M_{n c}\right)$ \\
\hline 1995 & $\begin{array}{l}1.200^{\star \star \star} \\
(0.167)\end{array}$ & $\begin{array}{l}0.637^{\star \star \star} \\
(0.157)\end{array}$ & $\begin{array}{l}0.563^{\star \star \star} \\
(0.141)\end{array}$ & & & & & & \\
\hline 1996 & $\begin{array}{l}1.111^{\star \star \star} \\
(0.156)\end{array}$ & $\begin{array}{l}0.728^{\star \star \star} \\
(0.152)\end{array}$ & $\begin{array}{l}0.382^{\star \star \star} \\
(0.134)\end{array}$ & & & & & & \\
\hline 1997 & $\begin{array}{l}1.153^{\star \star \star} \\
(0.144)\end{array}$ & $\begin{array}{l}0.591^{\star \star \star} \\
(0.140)\end{array}$ & $\begin{array}{l}0.562^{\star \star \star} \\
(0.126)\end{array}$ & $\begin{array}{l}1.185^{\star \star \star} \\
(0.164)\end{array}$ & $\begin{array}{l}0.831^{\star \star \star} \\
(0.167)\end{array}$ & $\begin{array}{l}0.354^{\star \star} \\
(0.153)\end{array}$ & & & \\
\hline 1998 & $\begin{array}{l}1.133^{\star \star \star} \\
(0.148)\end{array}$ & $\begin{array}{l}0.673^{\star \star \star} \\
(0.140)\end{array}$ & $\begin{array}{l}0.460^{\star \star \star} \\
(0.126)\end{array}$ & $\begin{array}{l}1.192^{\star \star \star} \\
(0.167)\end{array}$ & $\begin{array}{l}0.823^{\star \star \star} \\
(0.161)\end{array}$ & $\begin{array}{l}0.370^{\star \star} \\
(0.150)\end{array}$ & & & \\
\hline 1999 & $\begin{array}{l}1.183^{\star \star \star} \\
(0.142)\end{array}$ & $\begin{array}{l}0.523^{\star \star \star} \\
(0.135)\end{array}$ & $\begin{array}{l}0.660^{\star \star \star} \\
(0.125)\end{array}$ & $\begin{array}{l}1.229^{\star \star \star} \\
(0.166)\end{array}$ & $\begin{array}{l}0.670^{\star \star \star} \\
(0.158)\end{array}$ & $\begin{array}{l}0.559^{\star \star \star} \\
(0.149)\end{array}$ & $\begin{array}{l}1.141^{\star \star \star} \\
(0.177)\end{array}$ & $\begin{array}{l}0.666^{\star \star \star} \\
(0.168)\end{array}$ & $\begin{array}{l}0.475^{\star \star \star} \\
(0.160)\end{array}$ \\
\hline 2000 & $\begin{array}{l}1.198^{\star \star \star} \\
(0.139)\end{array}$ & $\begin{array}{l}0.671^{\star \star \star} \\
(0.134)\end{array}$ & $\begin{array}{l}0.527^{\star \star \star} \\
(0.125)\end{array}$ & $\begin{array}{l}1.268^{\star \star \star} \\
(0.163)\end{array}$ & $\begin{array}{l}0.727^{\star \star \star} \\
(0.158)\end{array}$ & $\begin{array}{l}0.540^{\star \star \star} \\
(0.149)\end{array}$ & $\begin{array}{l}1.135^{\star \star \star} \\
(0.173)\end{array}$ & $\begin{array}{l}0.703^{\star \star \star} \\
(0.168)\end{array}$ & $\begin{array}{l}0.432^{\star \star \star} \\
(0.158)\end{array}$ \\
\hline 2001 & $\begin{array}{l}1.057^{\star \star \star} \\
(0.142)\end{array}$ & $\begin{array}{l}0.634^{\star \star \star} \\
(0.137)\end{array}$ & $\begin{array}{l}0.423^{\star \star \star} \\
(0.125)\end{array}$ & $\begin{array}{l}1.204^{\star \star \star} \\
(0.162)\end{array}$ & $\begin{array}{l}0.812^{\star \star \star} \\
(0.154)\end{array}$ & $\begin{array}{l}0.392^{\star \star \star} \\
(0.149)\end{array}$ & $\begin{array}{l}1.037^{\star \star \star} \\
(0.171)\end{array}$ & $\begin{array}{l}0.809^{\star \star \star} \\
(0.164)\end{array}$ & $\begin{array}{l}0.228 \\
(0.156)\end{array}$ \\
\hline 2002 & $\begin{array}{l}1.204^{\star \star \star} \\
(0.138)\end{array}$ & $\begin{array}{l}0.755^{\star \star \star} \\
(0.138)\end{array}$ & $\begin{array}{l}0.449^{\star \star \star} \\
(0.128)\end{array}$ & $\begin{array}{l}1.218^{\star \star \star} \\
(0.163)\end{array}$ & $\begin{array}{l}0.871^{\star \star \star} \\
(0.164)\end{array}$ & $\begin{array}{l}0.347^{\star \star} \\
(0.153)\end{array}$ & $\begin{array}{l}1.049^{\star \star \star} \\
(0.171)\end{array}$ & $\begin{array}{l}0.829^{\star \star \star} \\
(0.172)\end{array}$ & $\begin{array}{l}0.220 \\
(0.161)\end{array}$ \\
\hline 2003 & & & & $\begin{array}{l}1.470^{\star \star \star} \\
(0.161)\end{array}$ & $\begin{array}{l}0.836^{\star \star \star} \\
(0.158)\end{array}$ & $\begin{array}{l}0.634^{\star \star \star} \\
(0.145)\end{array}$ & $\begin{array}{l}1.326^{\star \star \star} \\
(0.171)\end{array}$ & $\begin{array}{l}0.796^{\star \star \star} \\
(0.165)\end{array}$ & $\begin{array}{l}0.530^{\star \star \star} \\
(0.152)\end{array}$ \\
\hline 2004 & & & & $\begin{array}{l}1.618^{\star \star \star} \\
(0.157)\end{array}$ & $\begin{array}{l}0.913^{\star \star \star} \\
(0.148)\end{array}$ & $\begin{array}{l}0.705^{\star \star \star} \\
(0.147)\end{array}$ & $\begin{array}{l}1.404^{\star \star \star} \\
(0.165)\end{array}$ & $\begin{array}{l}0.776^{\star \star \star} \\
(0.156)\end{array}$ & $\begin{array}{l}0.628^{\star \star \star} \\
(0.155)\end{array}$ \\
\hline 2005 & & & & $\begin{array}{l}1.765^{\star \star \star} \\
(0.154)\end{array}$ & $\begin{array}{l}0.912^{\star \star \star} \\
(0.144)\end{array}$ & $\begin{array}{l}0.853^{\star \star \star} \\
(0.139)\end{array}$ & $\begin{array}{l}1.537^{\star \star \star} \\
(0.163)\end{array}$ & $\begin{array}{l}0.800^{\star \star \star} \\
(0.154)\end{array}$ & $\begin{array}{l}0.737^{\star \star \star} \\
(0.147)\end{array}$ \\
\hline 2006 & & & & $\begin{array}{l}1.487^{\star \star \star} \\
(0.154)\end{array}$ & $\begin{array}{l}0.678^{\star \star \star} \\
(0.143)\end{array}$ & $\begin{array}{l}0.810^{\star \star \star} \\
(0.140)\end{array}$ & $\begin{array}{l}1.217^{\star \star \star} \\
(0.162)\end{array}$ & $\begin{array}{l}0.603^{\star \star \star} \\
(0.149)\end{array}$ & $\begin{array}{l}0.613^{\star \star \star} \\
(0.145)\end{array}$ \\
\hline 2007 & & & & $\begin{array}{l}1.697^{\star \star \star} \\
(0.145)\end{array}$ & $\begin{array}{l}0.871^{\star \star \star} \\
(0.139)\end{array}$ & $\begin{array}{l}0.825^{\star \star \star} \\
(0.129)\end{array}$ & $\begin{array}{l}1.410^{\star \star \star} \\
(0.154)\end{array}$ & $\begin{array}{l}0.619^{\star \star \star} \\
(0.146)\end{array}$ & $\begin{array}{l}0.791^{\star \star \star} \\
(0.138)\end{array}$ \\
\hline
\end{tabular}

(b) $O_{n c}^{w}$, calculated with quintile and decile data from time span

\begin{tabular}{|c|c|c|c|c|c|c|c|c|c|}
\hline \multirow[b]{2}{*}{ year } & \multicolumn{3}{|c|}{1992 to 2002 (102 countries) } & \multicolumn{3}{|c|}{1997 to 2007 (91 countries) } & \multicolumn{3}{|c|}{1999 to 2009 (88 countries) } \\
\hline & $\ln \left(V_{n c}\right)$ & $\ln \left(E M_{n c}\right)$ & $\ln \left(I M_{n c}\right)$ & $\ln \left(V_{n c}\right)$ & $\ln \left(E M_{n c}\right)$ & $\ln \left(I M_{n c}\right)$ & $\ln \left(V_{n c}\right)$ & $\ln \left(E M_{n c}\right)$ & $\ln \left(I M_{n c}\right)$ \\
\hline 1995 & $\begin{array}{l}0.122^{\star \star \star} \\
(0.014)\end{array}$ & $\begin{array}{l}0.049^{\star \star \star} \\
(0.014)\end{array}$ & $\begin{array}{l}0.074^{\star \star \star} \\
(0.013)\end{array}$ & & & & & & \\
\hline 1996 & $\begin{array}{l}0.132^{\star \star \star} \\
(0.014)\end{array}$ & $\begin{array}{l}0.061^{\star \star \star} \\
(0.013)\end{array}$ & $\begin{array}{l}0.071^{\star \star \star} \\
(0.012)\end{array}$ & & & & & & \\
\hline 1997 & $\begin{array}{l}0.120^{\star \star \star} \\
(0.013)\end{array}$ & $\begin{array}{l}0.049^{\star \star \star} \\
(0.012)\end{array}$ & $\begin{array}{l}0.072^{\star \star \star} \\
(0.012)\end{array}$ & $\begin{array}{l}0.095^{\star \star \star} \\
(0.014)\end{array}$ & $\begin{array}{l}0.048^{\star \star \star} \\
(0.014)\end{array}$ & $\begin{array}{l}0.047^{\star \star \star} \\
(0.013)\end{array}$ & & & \\
\hline 1998 & $\begin{array}{l}0.113^{\star \star \star} \\
(0.013)\end{array}$ & $\begin{array}{l}0.038^{\star \star \star} \\
(0.013)\end{array}$ & $\begin{array}{l}0.075^{\star \star \star} \\
(0.011)\end{array}$ & $\begin{array}{l}0.094^{\star \star \star} \\
(0.014)\end{array}$ & $\begin{array}{l}0.031^{\star \star} \\
(0.014)\end{array}$ & $\begin{array}{l}0.063^{\star \star \star} \\
(0.013)\end{array}$ & & & \\
\hline 1999 & $\begin{array}{l}0.119^{\star \star \star} \\
(0.013)\end{array}$ & $\begin{array}{l}0.047^{\star \star \star} \\
(0.012)\end{array}$ & $\begin{array}{l}0.072^{\star \star \star} \\
(0.011)\end{array}$ & $\begin{array}{l}0.095^{\star \star \star} \\
(0.014)\end{array}$ & $\begin{array}{l}0.036^{\star \star \star} \\
(0.013)\end{array}$ & $\begin{array}{l}0.059^{\star \star \star} \\
(0.012)\end{array}$ & $\begin{array}{l}0.096^{\star \star \star} \\
(0.014)\end{array}$ & $\begin{array}{l}0.039^{\star \star \star} \\
(0.014)\end{array}$ & $\begin{array}{l}0.057^{\star \star \star} \\
(0.013)\end{array}$ \\
\hline 2000 & $\begin{array}{l}0.116^{\star \star \star} \\
(0.012)\end{array}$ & $\begin{array}{l}0.055^{\star \star \star} \\
(0.012)\end{array}$ & $\begin{array}{l}0.061^{\star \star \star} \\
(0.011)\end{array}$ & $\begin{array}{l}0.092^{\star \star \star} \\
(0.013)\end{array}$ & $\begin{array}{l}0.039^{\star \star \star} \\
(0.013)\end{array}$ & $\begin{array}{l}0.053^{\star \star \star} \\
(0.012)\end{array}$ & $\begin{array}{l}0.091^{\star \star \star} \\
(0.014)\end{array}$ & $\begin{array}{l}0.037^{\star \star \star} \\
(0.014)\end{array}$ & $\begin{array}{l}0.055^{\star \star \star} \\
(0.012)\end{array}$ \\
\hline 2001 & $\begin{array}{l}0.106^{\star \star \star} \\
(0.012)\end{array}$ & $\begin{array}{l}0.053^{\star \star \star} \\
(0.011)\end{array}$ & $\begin{array}{l}0.052^{\star \star \star} \\
(0.011)\end{array}$ & $\begin{array}{l}0.089^{\star \star \star} \\
(0.013)\end{array}$ & $\begin{array}{l}0.053^{\star \star \star} \\
(0.012)\end{array}$ & $\begin{array}{l}0.035^{\star \star \star} \\
(0.012)\end{array}$ & $\begin{array}{l}0.089^{\star \star \star} \\
(0.014)\end{array}$ & $\begin{array}{l}0.053^{\star \star \star} \\
(0.013)\end{array}$ & $\begin{array}{l}0.036^{\star \star \star} \\
(0.012)\end{array}$ \\
\hline 2002 & $\begin{array}{l}0.114^{\star \star \star} \\
(0.012)\end{array}$ & $\begin{array}{l}0.065^{\star \star \star} \\
(0.012)\end{array}$ & $\begin{array}{l}0.048^{\star \star \star} \\
(0.010)\end{array}$ & $\begin{array}{l}0.091^{\star \star \star} \\
(0.013)\end{array}$ & $\begin{array}{l}0.059^{\star \star \star} \\
(0.013)\end{array}$ & $\begin{array}{l}0.032^{\star \star \star} \\
(0.012)\end{array}$ & $\begin{array}{l}0.093^{\star \star \star} \\
(0.014)\end{array}$ & $\begin{array}{l}0.067^{\star \star \star} \\
(0.014)\end{array}$ & $\begin{array}{l}0.026^{\star \star} \\
(0.012)\end{array}$ \\
\hline 2003 & & & & $\begin{array}{l}0.117^{\star \star \star} \\
(0.013)\end{array}$ & $\begin{array}{l}0.071^{\star \star \star} \\
(0.013)\end{array}$ & $\begin{array}{l}0.047^{\star \star \star} \\
(0.012)\end{array}$ & $\begin{array}{l}0.113^{\star \star \star} \\
(0.014)\end{array}$ & $\begin{array}{l}0.074^{\star \star \star} \\
(0.014)\end{array}$ & $\begin{array}{l}0.040^{\star \star \star} \\
(0.012)\end{array}$ \\
\hline 2004 & & & & $\begin{array}{l}0.100^{\star \star \star} \\
(0.013)\end{array}$ & $\begin{array}{l}0.069^{\star \star \star} \\
(0.013)\end{array}$ & $\begin{array}{l}0.031^{\star \star \star} \\
(0.012)\end{array}$ & $\begin{array}{l}0.092^{\star \star \star} \\
(0.014)\end{array}$ & $\begin{array}{l}0.070^{\star \star \star} \\
(0.013)\end{array}$ & $\begin{array}{l}0.023^{\star} \\
(0.013)\end{array}$ \\
\hline 2005 & & & & $\begin{array}{l}0.112^{\star \star \star} \\
(0.013)\end{array}$ & $\begin{array}{l}0.061^{\star \star \star} \\
(0.012)\end{array}$ & $\begin{array}{l}0.050^{\star \star \star} \\
(0.011)\end{array}$ & $\begin{array}{l}0.107^{\star \star \star} \\
(0.014)\end{array}$ & $\begin{array}{l}0.065^{\star \star \star} \\
(0.012)\end{array}$ & $\begin{array}{l}0.042^{\star \star \star} \\
(0.012)\end{array}$ \\
\hline 2006 & & & & $\begin{array}{l}0.104^{\star \star \star} \\
(0.013)\end{array}$ & $\begin{array}{l}0.063^{\star \star \star} \\
(0.012)\end{array}$ & $\begin{array}{l}0.042^{\star \star \star} \\
(0.012)\end{array}$ & $\begin{array}{l}0.095^{\star \star \star} \\
(0.013)\end{array}$ & $\begin{array}{l}0.062^{\star \star \star} \\
(0.012)\end{array}$ & $\begin{array}{l}0.033^{\star \star \star} \\
(0.012)\end{array}$ \\
\hline 2007 & & & & $\begin{array}{l}0.103^{\star \star \star} \\
(0.013)\end{array}$ & $\begin{array}{l}0.055^{\star \star \star} \\
(0.012)\end{array}$ & $\begin{array}{l}0.047^{\star \star \star} \\
(0.011)\end{array}$ & $\begin{array}{l}0.094^{\star \star \star} \\
(0.013)\end{array}$ & $\begin{array}{l}0.046^{\star \star \star} \\
(0.011)\end{array}$ & $\begin{array}{l}0.048^{\star \star \star} \\
(0.011)\end{array}$ \\
\hline
\end{tabular}


[Table A7 continued]

(c) $O_{n c}$ and $O_{n c}^{\bar{x}}$, calculated with quintile and decile data from time span

\begin{tabular}{|c|c|c|c|c|c|c|c|c|c|c|}
\hline \multirow[b]{2}{*}{ year } & & \multicolumn{3}{|c|}{1992 to 2002 (102 countries) } & \multicolumn{3}{|c|}{1997 to 2007 (91 countries) } & \multicolumn{3}{|c|}{1999 to 2009 (88 countries) } \\
\hline & & $\ln \left(V_{n c}\right)$ & $\ln \left(E M_{n c}\right)$ & $\ln \left(I M_{n c}\right)$ & $\ln \left(V_{n c}\right)$ & $\ln \left(E M_{n c}\right)$ & $\ln \left(I M_{n c}\right)$ & $\ln \left(V_{n c}\right)$ & $\ln \left(E M_{n c}\right)$ & $\ln \left(I M_{n c}\right)$ \\
\hline \multirow[t]{2}{*}{1995} & $O_{n c}$ & $\begin{array}{l}0.748^{\star \star \star} \\
(0.171)\end{array}$ & $\begin{array}{l}0.444^{\star \star \star} \\
(0.164)\end{array}$ & $\begin{array}{l}0.304^{\star \star} \\
(0.147)\end{array}$ & & & & & & \\
\hline & $O_{n c}^{\bar{x}}$ & $\begin{array}{l}0.530^{\star \star \star} \\
(0.064)\end{array}$ & $\begin{array}{l}0.225^{\star \star \star} \\
(0.061)\end{array}$ & $\begin{array}{l}0.304^{\star \star \star} \\
(0.061)\end{array}$ & & & & & & \\
\hline \multirow[t]{2}{*}{1996} & $O_{n c}$ & $\begin{array}{l}0.670^{\star \star \star} \\
(0.157)\end{array}$ & $\begin{array}{l}0.513^{\star \star \star} \\
(0.157)\end{array}$ & $\begin{array}{l}0.157 \\
(0.141)\end{array}$ & & & & & & \\
\hline & $O_{n c}^{\bar{x}}$ & $\begin{array}{l}0.528^{\star \star \star} \\
(0.060)\end{array}$ & $\begin{array}{l}0.258^{\star \star \star} \\
(0.059)\end{array}$ & $\begin{array}{l}0.271^{\star \star \star} \\
(0.056)\end{array}$ & & & & & & \\
\hline \multirow[t]{2}{*}{1997} & $O_{n c}$ & $\begin{array}{l}0.764^{\star \star \star} \\
(0.146)\end{array}$ & $\begin{array}{l}0.388^{\star \star \star} \\
(0.145)\end{array}$ & $\begin{array}{l}0.376^{\star \star \star} \\
(0.132)\end{array}$ & $\begin{array}{l}0.836^{\star \star \star} \\
(0.170)\end{array}$ & $\begin{array}{l}0.672^{\star \star \star} \\
(0.175)\end{array}$ & $\begin{array}{l}0.164 \\
(0.163)\end{array}$ & & & \\
\hline & $O_{n c}^{\bar{x}}$ & $\begin{array}{l}0.455^{\star \star \star} \\
(0.057)\end{array}$ & $\begin{array}{l}0.237^{\star \star \star} \\
(0.055)\end{array}$ & $\begin{array}{l}0.218^{\star \star \star} \\
(0.053)\end{array}$ & $\begin{array}{l}0.317^{\star \star \star} \\
(0.060)\end{array}$ & $\begin{array}{l}0.144^{\star \star} \\
(0.057)\end{array}$ & $\begin{array}{l}0.173^{\star \star \star} \\
(0.057)\end{array}$ & & & \\
\hline \multirow[t]{2}{*}{1998} & $O_{n c}$ & $\begin{array}{l}0.767^{\star \star \star} \\
(0.151)\end{array}$ & $\begin{array}{l}0.516^{\star \star \star} \\
(0.146)\end{array}$ & $\begin{array}{l}0.251^{\star} \\
(0.130)\end{array}$ & $\begin{array}{l}0.860^{\star \star \star} \\
(0.174)\end{array}$ & $\begin{array}{l}0.758^{\star \star \star} \\
(0.173)\end{array}$ & $\begin{array}{l}0.102 \\
(0.158)\end{array}$ & & & \\
\hline & $O_{n c}^{\bar{x}}$ & $\begin{array}{l}0.406^{\star \star \star} \\
(0.056)\end{array}$ & $\begin{array}{l}0.174^{\star \star \star} \\
(0.055)\end{array}$ & $\begin{array}{l}0.232^{\star \star \star} \\
(0.050)\end{array}$ & $\begin{array}{l}0.289^{\star \star \star} \\
(0.057)\end{array}$ & $\begin{array}{l}0.056 \\
(0.057)\end{array}$ & $\begin{array}{l}0.233^{\star \star \star} \\
(0.054)\end{array}$ & & & \\
\hline \multirow[t]{2}{*}{1999} & $O_{n c}$ & $\begin{array}{l}0.770^{\star \star \star} \\
(0.143)\end{array}$ & $\begin{array}{l}0.284^{\star \star} \\
(0.141)\end{array}$ & $\begin{array}{l}0.486^{\star \star \star} \\
(0.129)\end{array}$ & $\begin{array}{l}0.836^{\star \star \star} \\
(0.171)\end{array}$ & $\begin{array}{l}0.505^{\star \star \star} \\
(0.168)\end{array}$ & $\begin{array}{l}0.331^{\star \star} \\
(0.160)\end{array}$ & $\begin{array}{l}0.734^{\star \star \star} \\
(0.186)\end{array}$ & $\begin{array}{l}0.530^{\star \star \star} \\
(0.181)\end{array}$ & $\begin{array}{l}0.204 \\
(0.175)\end{array}$ \\
\hline & $O_{n c}^{\bar{x}}$ & $\begin{array}{l}0.457^{\star \star \star} \\
(0.054)\end{array}$ & $\begin{array}{l}0.265^{\star \star \star} \\
(0.051)\end{array}$ & $\begin{array}{l}0.192^{\star \star \star} \\
(0.048)\end{array}$ & $\begin{array}{l}0.338^{\star \star \star} \\
(0.056)\end{array}$ & $\begin{array}{l}0.142^{\star \star \star} \\
(0.053)\end{array}$ & $\begin{array}{l}0.196^{\star \star \star} \\
(0.052)\end{array}$ & $\begin{array}{l}0.312^{\star \star \star} \\
(0.060)\end{array}$ & $\begin{array}{l}0.104^{\star} \\
(0.057)\end{array}$ & $\begin{array}{l}0.208^{\star \star \star} \\
(0.057)\end{array}$ \\
\hline \multirow[t]{2}{*}{2000} & $O_{n c}$ & $\begin{array}{l}0.785^{\star \star \star} \\
(0.144)\end{array}$ & $\begin{array}{l}0.461^{\star \star \star} \\
(0.140)\end{array}$ & $\begin{array}{l}0.324^{\star \star} \\
(0.132)\end{array}$ & $\begin{array}{l}0.889^{\star \star \star} \\
(0.172)\end{array}$ & $\begin{array}{l}0.571^{\star \star \star} \\
(0.168)\end{array}$ & $\begin{array}{l}0.318^{\star \star} \\
(0.161)\end{array}$ & $\begin{array}{l}0.731^{\star \star \star} \\
(0.188)\end{array}$ & $\begin{array}{l}0.564^{\star \star \star} \\
(0.181)\end{array}$ & $\begin{array}{l}0.167 \\
(0.177)\end{array}$ \\
\hline & $O_{n c}^{\bar{x}}$ & $\begin{array}{l}0.427^{\star \star \star} \\
(0.052)\end{array}$ & $\begin{array}{l}0.218^{\star \star \star} \\
(0.049)\end{array}$ & $\begin{array}{l}0.210^{\star \star \star} \\
(0.047)\end{array}$ & $\begin{array}{l}0.317^{\star \star \star} \\
(0.056)\end{array}$ & $\begin{array}{l}0.131^{\star \star} \\
(0.052)\end{array}$ & $\begin{array}{l}0.186^{\star \star \star} \\
(0.051)\end{array}$ & $\begin{array}{l}0.301^{\star \star \star} \\
(0.059)\end{array}$ & $\begin{array}{l}0.104^{\star} \\
(0.055)\end{array}$ & $\begin{array}{l}0.197^{\star \star \star} \\
(0.056)\end{array}$ \\
\hline \multirow[t]{2}{*}{2001} & $O_{n c}$ & $\begin{array}{l}0.717^{\star \star \star} \\
(0.147)\end{array}$ & $\begin{array}{l}0.427^{\star \star \star} \\
(0.145)\end{array}$ & $\begin{array}{l}0.290^{\star \star} \\
(0.131)\end{array}$ & $\begin{array}{l}0.892^{\star \star \star} \\
(0.169)\end{array}$ & $\begin{array}{l}0.645^{\star \star \star} \\
(0.165)\end{array}$ & $\begin{array}{l}0.246 \\
(0.158)\end{array}$ & $\begin{array}{l}0.715^{\star \star \star} \\
(0.183)\end{array}$ & $\begin{array}{l}0.672^{\star \star \star} \\
(0.179)\end{array}$ & $\begin{array}{l}0.043 \\
(0.171)\end{array}$ \\
\hline & $O_{n c}^{\bar{x}}$ & $\begin{array}{l}0.370^{\star \star \star} \\
(0.051)\end{array}$ & $\begin{array}{l}0.225^{\star \star \star} \\
(0.048)\end{array}$ & $\begin{array}{l}0.145^{\star \star \star} \\
(0.047)\end{array}$ & $\begin{array}{l}0.272^{\star \star \star} \\
(0.054)\end{array}$ & $\begin{array}{l}0.146^{\star \star \star} \\
(0.050)\end{array}$ & $\begin{array}{l}0.127^{\star \star} \\
(0.051)\end{array}$ & $\begin{array}{l}0.251^{\star \star \star} \\
(0.057)\end{array}$ & $\begin{array}{l}0.106^{\star \star} \\
(0.053)\end{array}$ & $\begin{array}{l}0.144^{\star \star \star} \\
(0.054)\end{array}$ \\
\hline \multirow[t]{2}{*}{2002} & $O_{n c}$ & $\begin{array}{l}0.838^{\star \star \star} \\
(0.142)\end{array}$ & $\begin{array}{l}0.518^{\star \star \star} \\
(0.144)\end{array}$ & $\begin{array}{l}0.320^{\star \star} \\
(0.136)\end{array}$ & $\begin{array}{l}0.876^{\star \star \star} \\
(0.170)\end{array}$ & $\begin{array}{l}0.632^{\star \star \star} \\
(0.176)\end{array}$ & $\begin{array}{l}0.244 \\
(0.165)\end{array}$ & $\begin{array}{l}0.680^{\star \star \star} \\
(0.183)\end{array}$ & $\begin{array}{l}0.554^{\star \star \star} \\
(0.188)\end{array}$ & $\begin{array}{l}0.126 \\
(0.178)\end{array}$ \\
\hline & $O_{n c}^{\bar{x}}$ & $\begin{array}{l}0.392^{\star \star \star} \\
(0.050)\end{array}$ & $\begin{array}{l}0.254^{\star \star \star} \\
(0.049)\end{array}$ & $\begin{array}{l}0.138^{\star \star \star} \\
(0.046)\end{array}$ & $\begin{array}{l}0.299^{\star \star \star} \\
(0.053)\end{array}$ & $\begin{array}{l}0.209^{\star \star \star} \\
(0.052)\end{array}$ & $\begin{array}{l}0.09 \star^{\star} \\
(0.051)\end{array}$ & $\begin{array}{l}0.292^{\star \star \star} \\
(0.057)\end{array}$ & $\begin{array}{l}0.217^{\star \star \star} \\
(0.055)\end{array}$ & $\begin{array}{l}0.074 \\
(0.055)\end{array}$ \\
\hline \multirow[t]{2}{*}{2003} & $O_{n c}$ & & & & $\begin{array}{l}1.000^{\star \star \star} \\
(0.166)\end{array}$ & $\begin{array}{l}0.570^{\star \star \star} \\
(0.167)\end{array}$ & $\begin{array}{l}0.429^{\star \star \star} \\
(0.153)\end{array}$ & $\begin{array}{l}0.821^{\star \star \star} \\
(0.181)\end{array}$ & $\begin{array}{l}0.489^{\star \star \star} \\
(0.179)\end{array}$ & $\begin{array}{l}0.333^{\star \star} \\
(0.165)\end{array}$ \\
\hline & $O_{n c}^{\bar{x}}$ & & & & $\begin{array}{l}0.426^{\star \star \star} \\
(0.052)\end{array}$ & $\begin{array}{l}0.241^{\star \star \star} \\
(0.051)\end{array}$ & $\begin{array}{l}0.185^{\star \star \star} \\
(0.047)\end{array}$ & $\begin{array}{l}0.413^{\star \star \star} \\
(0.057)\end{array}$ & $\begin{array}{l}0.251^{\star \star \star} \\
(0.055)\end{array}$ & $\begin{array}{l}0.161^{\star \star \star} \\
(0.050)\end{array}$ \\
\hline \multirow[t]{2}{*}{2004} & $O_{n c}$ & & & & $\begin{array}{l}1.298^{\star \star \star} \\
(0.161)\end{array}$ & $\begin{array}{l}0.714^{\star \star \star} \\
(0.152)\end{array}$ & $\begin{array}{l}0.583^{\star \star \star} \\
(0.151)\end{array}$ & $\begin{array}{l}1.113^{\star \star \star} \\
(0.174)\end{array}$ & $\begin{array}{l}0.572^{\star \star \star} \\
(0.163)\end{array}$ & $\begin{array}{l}0.541^{\star \star \star} \\
(0.164)\end{array}$ \\
\hline & $O_{n c}^{\bar{x}}$ & & & & $\begin{array}{l}0.309^{\star \star \star} \\
(0.052)\end{array}$ & $\begin{array}{l}0.191^{\star \star \star} \\
(0.047)\end{array}$ & $\begin{array}{l}0.117^{\star \star} \\
(0.048)\end{array}$ & $\begin{array}{l}0.257^{\star \star \star} \\
(0.056)\end{array}$ & $\begin{array}{l}0.180^{\star \star \star} \\
(0.050)\end{array}$ & $\begin{array}{l}0.077 \\
(0.052)\end{array}$ \\
\hline \multirow[t]{2}{*}{2005} & $O_{n c}$ & & & & $\begin{array}{l}1.442^{\star \star \star} \\
(0.160)\end{array}$ & $\begin{array}{l}0.756^{\star \star \star} \\
(0.149)\end{array}$ & $\begin{array}{l}0.687^{\star \star \star} \\
(0.144)\end{array}$ & $\begin{array}{l}1.232^{\star \star \star} \\
(0.173)\end{array}$ & $\begin{array}{l}0.637^{\star \star \star} \\
(0.162)\end{array}$ & $\begin{array}{l}0.595^{\star \star \star} \\
(0.156)\end{array}$ \\
\hline & $O_{n c}^{\bar{x}}$ & & & & $\begin{array}{l}0.307^{\star \star \star} \\
(0.050)\end{array}$ & $\begin{array}{l}0.149^{\star \star \star} \\
(0.046)\end{array}$ & $\begin{array}{l}0.159^{\star \star \star} \\
(0.045)\end{array}$ & $\begin{array}{l}0.262^{\star \star \star} \\
(0.054)\end{array}$ & $\begin{array}{l}0.140^{\star \star \star} \\
(0.048)\end{array}$ & $\begin{array}{l}0.122^{\star \star} \\
(0.048)\end{array}$ \\
\hline \multirow[t]{2}{*}{2006} & $O_{n c}$ & & & & $\begin{array}{l}1.152^{\star \star \star} \\
(0.154)\end{array}$ & $\begin{array}{l}0.494^{\star \star \star} \\
(0.145)\end{array}$ & $\begin{array}{l}0.658^{\star \star \star} \\
(0.144)\end{array}$ & $\begin{array}{l}0.922^{\star \star \star} \\
(0.166)\end{array}$ & $\begin{array}{l}0.431^{\star \star \star} \\
(0.154)\end{array}$ & $\begin{array}{l}0.491^{\star \star \star} \\
(0.152)\end{array}$ \\
\hline & $O_{n c}^{\bar{x}}$ & & & & $\begin{array}{l}0.329^{\star \star \star} \\
(0.049)\end{array}$ & $\begin{array}{l}0.180^{\star \star \star} \\
(0.046)\end{array}$ & $\begin{array}{l}0.149^{\star \star \star} \\
(0.045)\end{array}$ & $\begin{array}{l}0.261^{\star \star \star} \\
(0.052)\end{array}$ & $\begin{array}{l}0.153^{\star \star \star} \\
(0.046)\end{array}$ & $\begin{array}{l}0.109^{\star \star} \\
(0.048)\end{array}$ \\
\hline \multirow[t]{2}{*}{2007} & $O_{n c}$ & & & & $\begin{array}{l}1.433^{\star \star \star} \\
(0.147)\end{array}$ & $\begin{array}{l}0.744^{\star \star \star} \\
(0.142)\end{array}$ & $\begin{array}{l}0.689^{\star \star \star} \\
(0.134)\end{array}$ & $\begin{array}{l}1.186^{\star \star \star} \\
(0.158)\end{array}$ & $\begin{array}{l}0.520^{\star \star \star} \\
(0.152)\end{array}$ & $\begin{array}{l}0.666^{\star \star \star} \\
(0.144)\end{array}$ \\
\hline & $O_{n c}^{\bar{x}}$ & & & & $\begin{array}{l}0.254^{\star \star \star} \\
(0.047)\end{array}$ & $\begin{array}{l}0.122^{\star \star \star} \\
(0.044)\end{array}$ & $\begin{array}{l}0.131^{\star \star \star} \\
(0.043)\end{array}$ & $\begin{array}{l}0.197^{\star \star \star} \\
(0.050)\end{array}$ & $\begin{array}{l}0.087^{\star} \\
(0.046)\end{array}$ & $\begin{array}{l}0.110^{\star \star} \\
(0.046)\end{array}$ \\
\hline
\end{tabular}

Notes: ${ }^{\star \star \star},{ }^{\star \star},{ }^{\star}$ denote statistical significance on the $1 \%, 5 \%$, and $10 \%$ level, respectively. Robust standard errors (clustered by country pairs) are given in parentheses. Controls: geographic distance, dummies for free trade agreement, currency union, common border, common legal system, common language, colonial ties, dummy variable allowing for a different intercept for NN, SS, NS and SN trade flows $\left(\tau_{n c}\right)$, importer and exporter fixed effects $\left(A_{c}\right.$ and $\left.A_{n}\right)$. Sample: countries with population $>$ 1 million, HS6 codes which include consumer goods. This table reports the estimation results from equation [13), estimated for each year separately. The dependent variables are defined in equations $95-(11$. The income similarity measures are defined in equations $(4)-(6)$. 
Table A8: $\widetilde{Y}_{n c}-$ All Years

(a) $O_{n c}$, calculated with quintile and decile data from time span

\begin{tabular}{|c|c|c|c|c|c|c|c|c|c|}
\hline \multirow[b]{2}{*}{ year } & \multicolumn{3}{|c|}{1992 to 2002 (102 countries) } & \multicolumn{3}{|c|}{1997 to 2007 (91 countries) } & \multicolumn{3}{|c|}{1999 to 2009 (88 countries) } \\
\hline & $\ln \left(\widetilde{V}_{n c}\right)$ & $\ln \left(\widetilde{E M}_{n c}\right)$ & $\ln \left(\widehat{I M}_{n c}\right)$ & $\ln \left(\widetilde{V}_{n c}\right)$ & $\ln \left(\widetilde{E M}_{n c}\right)$ & $\ln \left(\widetilde{I M}_{n c}\right)$ & $\ln \left(\widetilde{V}_{n c}\right)$ & $\ln \left(\widetilde{E M}_{n c}\right)$ & $\ln \left(\widetilde{I M}_{n c}\right)$ \\
\hline 1995 & $\begin{array}{l}1.225^{\star \star \star} \\
(0.165)\end{array}$ & $\begin{array}{l}0.465^{\star \star \star} \\
(0.093)\end{array}$ & $\begin{array}{l}0.760^{\star \star \star} \\
(0.113)\end{array}$ & & & & & & \\
\hline 1996 & $\begin{array}{l}1.106^{\star \star \star} \\
(0.154)\end{array}$ & $\begin{array}{l}0.426^{\star \star \star} \\
(0.089)\end{array}$ & $\begin{array}{l}0.680^{\star \star \star} \\
(0.105)\end{array}$ & & & & & & \\
\hline 1997 & $\begin{array}{l}1.195^{\star \star \star} \\
(0.144)\end{array}$ & $\begin{array}{l}0.480^{\star \star \star} \\
(0.084)\end{array}$ & $\begin{array}{l}0.715^{\star \star \star} \\
(0.099)\end{array}$ & $\begin{array}{l}1.211^{\star \star \star} \\
(0.163)\end{array}$ & $\begin{array}{l}0.566^{\star \star \star} \\
(0.096)\end{array}$ & $\begin{array}{l}0.645^{\star \star \star} \\
(0.116)\end{array}$ & & & \\
\hline 1998 & $\begin{array}{l}1.159^{\star \star \star} \\
(0.147)\end{array}$ & $\begin{array}{l}0.469^{\star \star \star} \\
(0.081)\end{array}$ & $\begin{array}{l}0.691^{\star \star \star} \\
(0.101)\end{array}$ & $\begin{array}{l}1.225^{\star \star \star} \\
(0.166)\end{array}$ & $\begin{array}{l}0.542^{\star \star \star} \\
(0.093)\end{array}$ & $\begin{array}{l}0.683^{\star \star \star} \\
(0.116)\end{array}$ & & & \\
\hline 1999 & $\begin{array}{l}1.208^{\star \star \star} \\
(0.142)\end{array}$ & $\begin{array}{l}0.526^{\star \star \star} \\
(0.080)\end{array}$ & $\begin{array}{l}0.682^{\star \star \star} \\
(0.099)\end{array}$ & $\begin{array}{l}1.257^{\star \star \star} \\
(0.165)\end{array}$ & $\begin{array}{l}0.603^{\star \star \star} \\
(0.091)\end{array}$ & $\begin{array}{l}0.654^{\star \star \star} \\
(0.116)\end{array}$ & $\begin{array}{l}1.172^{\star \star \star} \\
(0.177)\end{array}$ & $\begin{array}{l}0.562^{\star \star \star} \\
(0.098)\end{array}$ & $\begin{array}{l}0.611^{\star \star \star} \\
(0.124)\end{array}$ \\
\hline 2000 & $\begin{array}{l}1.225^{\star \star \star} \\
(0.139)\end{array}$ & $\begin{array}{l}0.581^{\star \star \star} \\
(0.079)\end{array}$ & $\begin{array}{l}0.645^{\star \star \star} \\
(0.096)\end{array}$ & $\begin{array}{l}1.294^{\star \star \star} \\
(0.162)\end{array}$ & $\begin{array}{l}0.606^{\star \star \star} \\
(0.091)\end{array}$ & $\begin{array}{l}0.688^{\star \star \star} \\
(0.114)\end{array}$ & $\begin{array}{l}1.147^{\star \star \star} \\
(0.172)\end{array}$ & $\begin{array}{l}0.516^{\star \star \star} \\
(0.098)\end{array}$ & $\begin{array}{l}0.631^{\star \star \star} \\
(0.120)\end{array}$ \\
\hline 2001 & $\begin{array}{l}1.063^{\star \star \star} \\
(0.141)\end{array}$ & $\begin{array}{l}0.500^{\star \star \star} \\
(0.080)\end{array}$ & $\begin{array}{l}0.563^{\star \star \star} \\
(0.096)\end{array}$ & $\begin{array}{l}1.200^{\star \star \star} \\
(0.162)\end{array}$ & $\begin{array}{l}0.569^{\star \star \star} \\
(0.091)\end{array}$ & $\begin{array}{l}0.631^{\star \star \star} \\
(0.112)\end{array}$ & $\begin{array}{l}1.039^{\star \star \star} \\
(0.170)\end{array}$ & $\begin{array}{l}0.488^{\star \star \star} \\
(0.097)\end{array}$ & $\begin{array}{l}0.550^{\star \star \star} \\
(0.117)\end{array}$ \\
\hline 2002 & $\begin{array}{l}1.216^{\star \star \star} \\
(0.137)\end{array}$ & $\begin{array}{l}0.646^{\star \star \star} \\
(0.079)\end{array}$ & $\begin{array}{l}0.570^{\star \star \star} \\
(0.095)\end{array}$ & $\begin{array}{l}1.222^{\star \star \star} \\
(0.162)\end{array}$ & $\begin{array}{l}0.666^{\star \star \star} \\
(0.091)\end{array}$ & $\begin{array}{l}0.556^{\star \star \star} \\
(0.114)\end{array}$ & $\begin{array}{l}1.051^{\star \star \star} \\
(0.170)\end{array}$ & $\begin{array}{l}0.586^{\star \star \star} \\
(0.098)\end{array}$ & $\begin{array}{l}0.464^{\star \star \star} \\
(0.119)\end{array}$ \\
\hline 2003 & & & & $\begin{array}{l}1.447^{\star \star \star} \\
(0.160)\end{array}$ & $\begin{array}{l}0.691^{\star \star \star} \\
(0.089)\end{array}$ & $\begin{array}{l}0.756^{\star \star \star} \\
(0.112)\end{array}$ & $\begin{array}{l}1.304^{\star \star \star} \\
(0.170)\end{array}$ & $\begin{array}{l}0.598^{\star \star \star} \\
(0.096)\end{array}$ & $\begin{array}{l}0.706^{\star \star \star} \\
(0.119)\end{array}$ \\
\hline 2004 & & & & $\begin{array}{l}1.618^{\star \star \star} \\
(0.156)\end{array}$ & $\begin{array}{l}0.731^{\star \star \star} \\
(0.087)\end{array}$ & $\begin{array}{l}0.887^{\star \star \star} \\
(0.108)\end{array}$ & $\begin{array}{l}1.414^{\star \star \star} \\
(0.164)\end{array}$ & $\begin{array}{l}0.597^{\star \star \star} \\
(0.092)\end{array}$ & $\begin{array}{l}0.817^{\star \star \star} \\
(0.115)\end{array}$ \\
\hline 2005 & & & & $\begin{array}{l}1.744^{\star \star \star} \\
(0.154)\end{array}$ & $\begin{array}{l}0.695^{\star \star \star} \\
(0.082)\end{array}$ & $\begin{array}{l}1.049^{\star \star \star} \\
(0.107)\end{array}$ & $\begin{array}{l}1.516^{\star \star \star} \\
(0.162)\end{array}$ & $\begin{array}{l}0.565^{\star \star \star} \\
(0.087)\end{array}$ & $\begin{array}{l}0.951^{\star \star \star} \\
(0.113)\end{array}$ \\
\hline 2006 & & & & $\begin{array}{l}1.474^{\star \star \star} \\
(0.153)\end{array}$ & $\begin{array}{l}0.594^{\star \star \star} \\
(0.082)\end{array}$ & $\begin{array}{l}0.880^{\star \star \star} \\
(0.107)\end{array}$ & $\begin{array}{l}1.205^{\star \star \star} \\
(0.160)\end{array}$ & $\begin{array}{l}0.459^{\star \star \star} \\
(0.087)\end{array}$ & $\begin{array}{l}0.746^{\star \star \star} \\
(0.113)\end{array}$ \\
\hline 2007 & & & & $\begin{array}{l}1.690^{\star \star \star} \\
(0.145)\end{array}$ & $\begin{array}{l}0.616^{\star \star \star} \\
(0.078)\end{array}$ & $\begin{array}{l}1.074^{\star \star \star} \\
(0.102)\end{array}$ & $\begin{array}{l}1.405^{\star \star \star} \\
(0.154)\end{array}$ & $\begin{array}{l}0.476^{\star \star \star} \\
(0.083)\end{array}$ & $\begin{array}{l}0.929^{\star \star \star} \\
(0.109)\end{array}$ \\
\hline
\end{tabular}

(b) $O_{n c}^{w}$, calculated with quintile and decile data from time span

\begin{tabular}{|c|c|c|c|c|c|c|c|c|c|}
\hline \multirow[b]{2}{*}{ year } & \multicolumn{3}{|c|}{1992 to 2002 (102 countries) } & \multicolumn{3}{|c|}{1997 to 2007 (91 countries) } & \multicolumn{3}{|c|}{1999 to 2009 (88 countries) } \\
\hline & $\ln \left(\widetilde{V}_{n c}\right)$ & $\ln \left(\widetilde{E M}_{n c}\right)$ & $\ln \left(\widetilde{I M}_{n c}\right)$ & $\ln \left(\widetilde{V}_{n c}\right)$ & $\ln \left(\widetilde{E M}_{n c}\right)$ & $\ln \left(\widetilde{I M}_{n c}\right)$ & $\ln \left(\widetilde{V}_{n c}\right)$ & $\ln \left(\widetilde{E M}_{n c}\right)$ & $\ln \left(\widetilde{I M}_{n c}\right)$ \\
\hline 1995 & $\begin{array}{l}0.126^{\star \star \star} \\
(0.014)\end{array}$ & $\begin{array}{l}0.039^{\star \star \star} \\
(0.008)\end{array}$ & $\begin{array}{l}0.087^{\star \star \star} \\
(0.010)\end{array}$ & & & & & & \\
\hline 1996 & $\begin{array}{l}0.130^{\star \star \star} \\
(0.014)\end{array}$ & $\begin{array}{l}0.046^{\star \star \star} \\
(0.008)\end{array}$ & $\begin{array}{l}0.084^{\star \star \star} \\
(0.009)\end{array}$ & & & & & & \\
\hline 1997 & $\begin{array}{l}0.124^{\star \star \star} \\
(0.013)\end{array}$ & $\begin{array}{l}0.046^{\star \star \star} \\
(0.008)\end{array}$ & $\begin{array}{l}0.078^{\star \star \star} \\
(0.009)\end{array}$ & $\begin{array}{l}0.098^{\star \star \star} \\
(0.014)\end{array}$ & $\begin{array}{l}0.039^{\star \star \star \star} \\
(0.008)\end{array}$ & $\begin{array}{l}0.060^{\star \star \star} \\
(0.010)\end{array}$ & & & \\
\hline 1998 & $\begin{array}{l}0.115^{\star \star \star} \\
(0.013)\end{array}$ & $\begin{array}{l}0.035^{\star \star \star} \\
(0.007)\end{array}$ & $\begin{array}{l}0.080^{\star \star \star} \\
(0.009)\end{array}$ & $\begin{array}{l}0.095^{\star \star \star} \\
(0.014)\end{array}$ & $\begin{array}{l}0.027^{\star \star \star} \\
(0.008)\end{array}$ & $\begin{array}{l}0.068^{\star \star \star} \\
(0.010)\end{array}$ & & & \\
\hline 1999 & $\begin{array}{l}0.119^{\star \star \star} \\
(0.012)\end{array}$ & $\begin{array}{l}0.042^{\star \star \star} \\
(0.007)\end{array}$ & $\begin{array}{l}0.077^{\star \star \star} \\
(0.009)\end{array}$ & $\begin{array}{l}0.096^{\star \star \star} \\
(0.013)\end{array}$ & $\begin{array}{l}0.033^{\star \star \star} \\
(0.008)\end{array}$ & $\begin{array}{l}0.062^{\star \star \star} \\
(0.009)\end{array}$ & $\begin{array}{l}0.097^{\star \star \star} \\
(0.014)\end{array}$ & $\begin{array}{l}0.038^{\star \star \star} \\
(0.008)\end{array}$ & $\begin{array}{l}0.059^{\star \star \star} \\
(0.010)\end{array}$ \\
\hline 2000 & $\begin{array}{l}0.119^{\star \star \star} \\
(0.012)\end{array}$ & $\begin{array}{l}0.046^{\star \star \star} \\
(0.007)\end{array}$ & $\begin{array}{l}0.072^{\star \star \star} \\
(0.008)\end{array}$ & $\begin{array}{l}0.094^{\star \star \star} \\
(0.013)\end{array}$ & $\begin{array}{l}0.033^{\star \star \star} \\
(0.007)\end{array}$ & $\begin{array}{l}0.061^{\star \star \star} \\
(0.009)\end{array}$ & $\begin{array}{l}0.092^{\star \star \star} \\
(0.014)\end{array}$ & $\begin{array}{l}0.034^{\star \star \star} \\
(0.008)\end{array}$ & $\begin{array}{l}0.058^{\star \star \star} \\
(0.010)\end{array}$ \\
\hline 2001 & $\begin{array}{l}0.106^{\star \star \star} \\
(0.012)\end{array}$ & $\begin{array}{l}0.037^{\star \star \star} \\
(0.007)\end{array}$ & $\begin{array}{l}0.069^{\star \star \star} \\
(0.008)\end{array}$ & $\begin{array}{l}0.089^{\star \star \star} \\
(0.013)\end{array}$ & $\begin{array}{l}0.032^{\star \star \star} \\
(0.007)\end{array}$ & $\begin{array}{l}0.057^{\star \star \star} \\
(0.009)\end{array}$ & $\begin{array}{l}0.089^{\star \star \star} \\
(0.013)\end{array}$ & $\begin{array}{l}0.032^{\star \star \star} \\
(0.008)\end{array}$ & $\begin{array}{l}0.058^{\star \star \star} \\
(0.009)\end{array}$ \\
\hline 2002 & $\begin{array}{l}0.115^{\star \star \star} \\
(0.012)\end{array}$ & $\begin{array}{l}0.047^{\star \star \star} \\
(0.007)\end{array}$ & $\begin{array}{l}0.068^{\star \star \star} \\
(0.008)\end{array}$ & $\begin{array}{l}0.092^{\star \star \star} \\
(0.013)\end{array}$ & $\begin{array}{l}0.037^{\star \star \star} \\
(0.007)\end{array}$ & $\begin{array}{l}0.055^{\star \star \star} \\
(0.009)\end{array}$ & $\begin{array}{l}0.094^{\star \star \star} \\
(0.014)\end{array}$ & $\begin{array}{l}0.039^{\star \star \star} \\
(0.008)\end{array}$ & $\begin{array}{l}0.055^{\star \star \star} \\
(0.010)\end{array}$ \\
\hline 2003 & & & & $\begin{array}{l}0.116^{\star \star \star} \\
(0.013)\end{array}$ & $\begin{array}{l}0.038^{\star \star \star} \\
(0.007)\end{array}$ & $\begin{array}{l}0.078^{\star \star \star} \\
(0.009)\end{array}$ & $\begin{array}{l}0.112^{\star \star \star} \\
(0.014)\end{array}$ & $\begin{array}{l}0.039^{\star \star \star} \\
(0.008)\end{array}$ & $\begin{array}{l}0.073^{\star \star \star} \\
(0.010)\end{array}$ \\
\hline 2004 & & & & $\begin{array}{l}0.101^{\star \star \star} \\
(0.013)\end{array}$ & $\begin{array}{l}0.038^{\star \star \star} \\
(0.007)\end{array}$ & $\begin{array}{l}0.063^{\star \star \star} \\
(0.009)\end{array}$ & $\begin{array}{l}0.094^{\star \star \star} \\
(0.014)\end{array}$ & $\begin{array}{l}0.035^{\star \star \star} \\
(0.008)\end{array}$ & $\begin{array}{l}0.059^{\star \star \star} \\
(0.010)\end{array}$ \\
\hline 2005 & & & & $\begin{array}{l}0.110^{\star \star \star} \\
(0.013)\end{array}$ & $\begin{array}{l}0.036^{\star \star \star} \\
(0.007)\end{array}$ & $\begin{array}{l}0.075^{\star \star \star} \\
(0.009)\end{array}$ & $\begin{array}{l}0.106^{\star \star \star} \\
(0.014)\end{array}$ & $\begin{array}{l}0.035^{\star \star \star} \\
(0.007)\end{array}$ & $\begin{array}{l}0.071^{\star \star \star} \\
(0.010)\end{array}$ \\
\hline 2006 & & & & $\begin{array}{l}0.104^{\star \star \star} \\
(0.013)\end{array}$ & $\begin{array}{l}0.035^{\star \star \star} \\
(0.007)\end{array}$ & $\begin{array}{l}0.069^{\star \star \star} \\
(0.009)\end{array}$ & $\begin{array}{l}0.095^{\star \star \star} \\
(0.013)\end{array}$ & $\begin{array}{l}0.031^{\star \star \star} \\
(0.007)\end{array}$ & $\begin{array}{l}0.064^{\star \star \star} \\
(0.010)\end{array}$ \\
\hline 2007 & & & & $\begin{array}{l}0.103^{\star \star \star} \\
(0.013)\end{array}$ & $\begin{array}{l}0.028^{\star \star \star} \\
(0.007)\end{array}$ & $\begin{array}{l}0.075^{\star \star \star} \\
(0.009)\end{array}$ & $\begin{array}{l}0.094^{\star \star \star} \\
(0.013)\end{array}$ & $\begin{array}{l}0.025^{\star \star \star} \\
(0.007)\end{array}$ & $\begin{array}{l}0.069^{\star \star \star} \\
(0.009)\end{array}$ \\
\hline
\end{tabular}


[Table A8 continued]

(c) $O_{n c}$ and $O_{n c}^{\bar{x}}$, calculated with quintile and decile data from time span

\begin{tabular}{|c|c|c|c|c|c|c|c|c|c|c|}
\hline \multirow[b]{2}{*}{ year } & \multirow[b]{3}{*}{$O_{n c}$} & \multicolumn{3}{|c|}{1992 to 2002 (102 countries) } & \multicolumn{3}{|c|}{1997 to 2007 (91 countries) } & \multicolumn{3}{|c|}{1999 to 2009 (88 countries) } \\
\hline & & $\ln \left(\widetilde{V}_{n c}\right)$ & $\ln \left(\widetilde{E M}_{n c}\right)$ & $\ln \left(\widetilde{I M}_{n c}\right)$ & $\ln \left(\widetilde{V}_{n c}\right)$ & $\ln \left(\widetilde{E M}_{n c}\right)$ & $\ln \left(\widetilde{I M}_{n c}\right)$ & $\ln \left(\widetilde{V}_{n c}\right)$ & $\ln \left(\widetilde{E M}_{n c}\right)$ & $\ln \left(\widetilde{I M}_{n c}\right)$ \\
\hline \multirow[t]{2}{*}{1995} & & $\begin{array}{l}0.768^{\star \star \star} \\
(0.169)\end{array}$ & $\begin{array}{l}0.274^{\star \star \star} \\
(0.098)\end{array}$ & $\begin{array}{l}0.494^{\star \star \star} \\
(0.116)\end{array}$ & & & & & & \\
\hline & $O_{n c}^{\bar{x}}$ & $\begin{array}{l}0.531^{\star \star \star} \\
(0.064)\end{array}$ & $\begin{array}{l}0.222^{\star \star \star} \\
(0.036)\end{array}$ & $\begin{array}{l}0.309^{\star \star \star} \\
(0.045)\end{array}$ & & & & & & \\
\hline \multirow[t]{2}{*}{1996} & $O_{n c}$ & $\begin{array}{l}0.676^{\star \star \star} \\
(0.156)\end{array}$ & $\begin{array}{l}0.236^{\star \star} \\
(0.092)\end{array}$ & $\begin{array}{l}0.440^{\star \star \star} \\
(0.108)\end{array}$ & & & & & & \\
\hline & $O_{n c}^{\bar{x}}$ & $\begin{array}{l}0.514^{\star \star \star} \\
(0.059)\end{array}$ & $\begin{array}{l}0.227^{\star \star \star} \\
(0.035)\end{array}$ & $\begin{array}{l}0.287^{\star \star \star} \\
(0.043)\end{array}$ & & & & & & \\
\hline \multirow[t]{2}{*}{1997} & $O_{n c}$ & $\begin{array}{l}0.801^{\star \star \star} \\
(0.145)\end{array}$ & $\begin{array}{l}0.299^{\star \star \star} \\
(0.086)\end{array}$ & $\begin{array}{l}0.501^{\star \star \star} \\
(0.101)\end{array}$ & $\begin{array}{l}0.852^{\star \star \star} \\
(0.169)\end{array}$ & $\begin{array}{l}0.410^{\star \star \star} \\
(0.101)\end{array}$ & $\begin{array}{l}0.443^{\star \star \star} \\
(0.122)\end{array}$ & & & \\
\hline & $O_{n c}^{\bar{x}}$ & $\begin{array}{l}0.461^{\star \star \star} \\
(0.057)\end{array}$ & $\begin{array}{l}0.211^{\star \star \star} \\
(0.033)\end{array}$ & $\begin{array}{l}0.250^{\star \star \star} \\
(0.041)\end{array}$ & $\begin{array}{l}0.326^{\star \star \star} \\
(0.060)\end{array}$ & $\begin{array}{l}0.142^{\star \star \star} \\
(0.034)\end{array}$ & $\begin{array}{l}0.184^{\star \star \star} \\
(0.044)\end{array}$ & & & \\
\hline \multirow[t]{2}{*}{1998} & $O_{n c}$ & $\begin{array}{l}0.792^{\star \star \star} \\
(0.150)\end{array}$ & $\begin{array}{l}0.328^{\star \star \star} \\
(0.085)\end{array}$ & $\begin{array}{l}0.464^{\star \star \star} \\
(0.104)\end{array}$ & $\begin{array}{l}0.897^{\star \star \star} \\
(0.173)\end{array}$ & $\begin{array}{l}0.440^{\star \star \star} \\
(0.099)\end{array}$ & $\begin{array}{l}0.457^{\star \star \star} \\
(0.122)\end{array}$ & & & \\
\hline & $O_{n c}^{\bar{x}}$ & $\begin{array}{l}0.407^{\star \star \star} \\
(0.055)\end{array}$ & $\begin{array}{l}0.156^{\star \star \star} \\
(0.032)\end{array}$ & $\begin{array}{l}0.251^{\star \star \star} \\
(0.039)\end{array}$ & $\begin{array}{l}0.285^{\star \star \star} \\
(0.057)\end{array}$ & $\begin{array}{l}0.089^{\star \star \star} \\
(0.033)\end{array}$ & $\begin{array}{l}0.196^{\star \star \star} \\
(0.041)\end{array}$ & & & \\
\hline \multirow[t]{2}{*}{1999} & $O_{n c}$ & $\begin{array}{l}0.798^{\star \star \star} \\
(0.143)\end{array}$ & $\begin{array}{l}0.350^{\star \star \star} \\
(0.083)\end{array}$ & $\begin{array}{l}0.448^{\star \star \star} \\
(0.100)\end{array}$ & $\begin{array}{l}0.866^{\star \star \star} \\
(0.171)\end{array}$ & $\begin{array}{l}0.449^{\star \star \star} \\
(0.098)\end{array}$ & $\begin{array}{l}0.417^{\star \star \star} \\
(0.122)\end{array}$ & $\begin{array}{l}0.768^{\star \star \star} \\
(0.186)\end{array}$ & $\begin{array}{l}0.392^{\star \star \star} \\
(0.107)\end{array}$ & $\begin{array}{l}0.376^{\star \star \star} \\
(0.135)\end{array}$ \\
\hline & $O_{n c}^{\bar{x}}$ & $\begin{array}{l}0.452^{\star \star \star} \\
(0.053)\end{array}$ & $\begin{array}{l}0.193^{\star \star \star} \\
(0.032)\end{array}$ & $\begin{array}{l}0.259^{\star \star \star} \\
(0.038)\end{array}$ & $\begin{array}{l}0.336^{\star \star \star} \\
(0.056)\end{array}$ & $\begin{array}{l}0.132^{\star \star \star} \\
(0.033)\end{array}$ & $\begin{array}{l}0.204^{\star \star \star} \\
(0.041)\end{array}$ & $\begin{array}{l}0.309^{\star \star \star} \\
(0.060)\end{array}$ & $\begin{array}{l}0.130^{\star \star \star} \\
(0.035)\end{array}$ & $\begin{array}{l}0.179^{\star \star \star} \\
(0.045)\end{array}$ \\
\hline \multirow[t]{2}{*}{2000} & $O_{n c}$ & $\begin{array}{l}0.813^{\star \star \star} \\
(0.144)\end{array}$ & $\begin{array}{l}0.412^{\star \star \star} \\
(0.083)\end{array}$ & $\begin{array}{l}0.401^{\star \star \star} \\
(0.101)\end{array}$ & $\begin{array}{l}0.917^{\star \star \star} \\
(0.171)\end{array}$ & $\begin{array}{l}0.475^{\star \star \star} \\
(0.098)\end{array}$ & $\begin{array}{l}0.442^{\star \star \star} \\
(0.122)\end{array}$ & $\begin{array}{l}0.749^{\star \star \star} \\
(0.186)\end{array}$ & $\begin{array}{l}0.371^{\star \star \star} \\
(0.107)\end{array}$ & $\begin{array}{l}0.377^{\star \star \star} \\
(0.134)\end{array}$ \\
\hline & $O_{n c}^{\bar{x}}$ & $\begin{array}{l}0.425^{\star \star \star} \\
(0.052)\end{array}$ & $\begin{array}{l}0.174^{\star \star \star} \\
(0.030)\end{array}$ & $\begin{array}{l}0.251^{\star \star \star} \\
(0.036)\end{array}$ & $\begin{array}{l}0.315^{\star \star \star} \\
(0.055)\end{array}$ & $\begin{array}{l}0.109^{\star \star \star} \\
(0.031)\end{array}$ & $\begin{array}{l}0.205^{\star \star \star} \\
(0.040)\end{array}$ & $\begin{array}{l}0.297^{\star \star \star} \\
(0.059)\end{array}$ & $\begin{array}{l}0.108^{\star \star \star} \\
(0.033)\end{array}$ & $\begin{array}{l}0.189^{\star \star \star} \\
(0.043)\end{array}$ \\
\hline \multirow[t]{2}{*}{2001} & $O_{n c}$ & $\begin{array}{l}0.722^{\star \star \star} \\
(0.146)\end{array}$ & $\begin{array}{l}0.372^{\star \star \star} \\
(0.084)\end{array}$ & $\begin{array}{l}0.350^{\star \star \star} \\
(0.101)\end{array}$ & $\begin{array}{l}0.886^{\star \star \star} \\
(0.169)\end{array}$ & $\begin{array}{l}0.467^{\star \star \star} \\
(0.097)\end{array}$ & $\begin{array}{l}0.419^{\star \star \star} \\
(0.118)\end{array}$ & $\begin{array}{l}0.713^{\star \star \star} \\
(0.182)\end{array}$ & $\begin{array}{l}0.399^{\star \star \star} \\
(0.106)\end{array}$ & $\begin{array}{l}0.315^{\star \star} \\
(0.127)\end{array}$ \\
\hline & $O_{n c}^{\bar{x}}$ & $\begin{array}{l}0.369^{\star \star \star} \\
(0.051)\end{array}$ & $\begin{array}{l}0.139^{\star \star \star} \\
(0.029)\end{array}$ & $\begin{array}{l}0.230^{\star \star \star} \\
(0.036)\end{array}$ & $\begin{array}{l}0.273^{\star \star \star} \\
(0.053)\end{array}$ & $\begin{array}{l}0.089^{\star \star \star} \\
(0.030)\end{array}$ & $\begin{array}{l}0.184^{\star \star \star} \\
(0.039)\end{array}$ & $\begin{array}{l}0.253^{\star \star \star} \\
(0.057)\end{array}$ & $\begin{array}{l}0.070^{\star \star} \\
(0.032)\end{array}$ & $\begin{array}{l}0.183^{\star \star \star} \\
(0.042)\end{array}$ \\
\hline \multirow[t]{2}{*}{2002} & $O_{n c}$ & $\begin{array}{l}0.848^{\star \star \star} \\
(0.141)\end{array}$ & $\begin{array}{l}0.502^{\star \star \star} \\
(0.083)\end{array}$ & $\begin{array}{l}0.346^{\star \star \star} \\
(0.099)\end{array}$ & $\begin{array}{l}0.875^{\star \star \star} \\
(0.169)\end{array}$ & $\begin{array}{l}0.538^{\star \star \star} \\
(0.097)\end{array}$ & $\begin{array}{l}0.337^{\star \star \star} \\
(0.121)\end{array}$ & $\begin{array}{l}0.678^{\star \star \star} \\
(0.182)\end{array}$ & $\begin{array}{l}0.457^{\star \star \star} \\
(0.106)\end{array}$ & $\begin{array}{l}0.221^{\star} \\
(0.130)\end{array}$ \\
\hline & $O_{n c}^{\bar{x}}$ & $\begin{array}{l}0.392^{\star \star \star} \\
(0.050)\end{array}$ & $\begin{array}{l}0.153^{\star \star \star} \\
(0.029)\end{array}$ & $\begin{array}{l}0.238^{\star \star \star} \\
(0.035)\end{array}$ & $\begin{array}{l}0.302^{\star \star \star} \\
(0.052)\end{array}$ & $\begin{array}{l}0.112^{\star \star \star} \\
(0.030)\end{array}$ & $\begin{array}{l}0.190^{\star \star \star} \\
(0.039)\end{array}$ & $\begin{array}{l}0.294^{\star \star \star} \\
(0.056)\end{array}$ & $\begin{array}{l}0.102^{\star \star \star} \\
(0.032)\end{array}$ & $\begin{array}{l}0.192^{\star \star \star} \\
(0.042)\end{array}$ \\
\hline \multirow[t]{2}{*}{2003} & $O_{n c}$ & & & & $\begin{array}{l}0.983^{\star \star \star} \\
(0.166)\end{array}$ & $\begin{array}{l}0.556^{\star \star \star} \\
(0.094)\end{array}$ & $\begin{array}{l}0.427^{\star \star \star} \\
(0.117)\end{array}$ & $\begin{array}{l}0.807^{\star \star \star} \\
(0.181)\end{array}$ & $\begin{array}{l}0.451^{\star \star \star} \\
(0.104)\end{array}$ & $\begin{array}{l}0.355^{\star \star \star} \\
(0.128)\end{array}$ \\
\hline & $O_{n c}^{\bar{x}}$ & & & & $\begin{array}{l}0.418^{\star \star \star} \\
(0.052)\end{array}$ & $\begin{array}{l}0.122^{\star \star \star} \\
(0.030)\end{array}$ & $\begin{array}{l}0.296^{\star \star \star} \\
(0.038)\end{array}$ & $\begin{array}{l}0.405^{\star \star \star} \\
(0.057)\end{array}$ & $\begin{array}{l}0.120^{\star \star \star} \\
(0.032)\end{array}$ & $\begin{array}{l}0.285^{\star \star \star} \\
(0.041)\end{array}$ \\
\hline \multirow[t]{2}{*}{2004} & $O_{n c}$ & & & & $\begin{array}{l}1.292^{\star \star \star} \\
(0.160)\end{array}$ & $\begin{array}{l}0.616^{\star \star \star} \\
(0.090)\end{array}$ & $\begin{array}{l}0.676^{\star \star \star} \\
(0.112)\end{array}$ & $\begin{array}{l}1.116^{\star \star \star} \\
(0.173)\end{array}$ & $\begin{array}{l}0.497^{\star \star \star} \\
(0.098)\end{array}$ & $\begin{array}{l}0.619^{\star \star \star} \\
(0.121)\end{array}$ \\
\hline & $O_{n c}^{\bar{x}}$ & & & & $\begin{array}{l}0.312^{\star \star \star} \\
(0.052)\end{array}$ & $\begin{array}{l}0.109^{\star \star \star} \\
(0.029)\end{array}$ & $\begin{array}{l}0.202^{\star \star \star} \\
(0.037)\end{array}$ & $\begin{array}{l}0.261^{\star \star \star} \\
(0.056)\end{array}$ & $\begin{array}{l}0.088^{\star \star \star} \\
(0.031)\end{array}$ & $\begin{array}{l}0.173^{\star \star \star} \\
(0.040)\end{array}$ \\
\hline \multirow[t]{2}{*}{2005} & $O_{n c}$ & & & & $\begin{array}{l}1.420^{\star \star \star} \\
(0.159)\end{array}$ & $\begin{array}{l}0.600^{\star \star \star} \\
(0.085)\end{array}$ & $\begin{array}{l}0.820^{\star \star \star} \\
(0.112)\end{array}$ & $\begin{array}{l}1.210^{\star \star \star} \\
(0.172)\end{array}$ & $\begin{array}{l}0.479^{\star \star \star} \\
(0.092)\end{array}$ & $\begin{array}{l}0.731^{\star \star \star} \\
(0.120)\end{array}$ \\
\hline & $O_{n c}^{\bar{x}}$ & & & & $\begin{array}{l}0.308^{\star \star \star} \\
(0.050)\end{array}$ & $\begin{array}{l}0.090^{\star \star \star} \\
(0.028)\end{array}$ & $\begin{array}{l}0.218^{\star \star \star} \\
(0.036)\end{array}$ & $\begin{array}{l}0.262^{\star \star \star} \\
(0.054)\end{array}$ & $\begin{array}{l}0.074^{\star \star} \\
(0.029)\end{array}$ & $\begin{array}{l}0.189^{\star \star \star} \\
(0.038)\end{array}$ \\
\hline \multirow[t]{2}{*}{2006} & $O_{n c}$ & & & & $\begin{array}{l}1.143^{\star \star \star} \\
(0.153)\end{array}$ & $\begin{array}{l}0.487^{\star \star \star} \\
(0.083)\end{array}$ & $\begin{array}{l}0.657^{\star \star \star} \\
(0.108)\end{array}$ & $\begin{array}{l}0.917^{\star \star \star} \\
(0.164)\end{array}$ & $\begin{array}{l}0.372^{\star \star \star} \\
(0.090)\end{array}$ & $\begin{array}{l}0.545^{\star \star \star} \\
(0.116)\end{array}$ \\
\hline & $O_{n c}^{\bar{x}}$ & & & & $\begin{array}{l}0.324^{\star \star \star} \\
(0.049)\end{array}$ & $\begin{array}{l}0.105^{\star \star \star} \\
(0.027)\end{array}$ & $\begin{array}{l}0.219^{\star \star \star} \\
(0.036)\end{array}$ & $\begin{array}{l}0.254^{\star \star \star} \\
(0.051)\end{array}$ & $\begin{array}{l}0.076^{\star \star \star} \\
(0.028)\end{array}$ & $\begin{array}{l}0.178^{\star \star \star} \\
(0.038)\end{array}$ \\
\hline \multirow[t]{2}{*}{2007} & $O_{n c}$ & & & & $\begin{array}{l}1.423^{\star \star \star} \\
(0.146)\end{array}$ & $\begin{array}{l}0.563^{\star \star \star} \\
(0.080)\end{array}$ & $\begin{array}{l}0.860^{\star \star \star} \\
(0.104)\end{array}$ & $\begin{array}{l}1.178^{\star \star \star} \\
(0.158)\end{array}$ & $\begin{array}{l}0.448^{\star \star \star} \\
(0.086)\end{array}$ & $\begin{array}{l}0.730^{\star \star \star} \\
(0.112)\end{array}$ \\
\hline & $O_{n c}^{\bar{x}}$ & & & & $\begin{array}{l}0.256^{\star \star \star} \\
(0.047)\end{array}$ & $\begin{array}{l}0.051^{\star \star} \\
(0.026)\end{array}$ & $\begin{array}{l}0.205^{\star \star \star} \\
(0.034)\end{array}$ & $\begin{array}{l}0.199^{\star \star \star} \\
(0.050)\end{array}$ & $\begin{array}{l}0.024 \\
(0.027)\end{array}$ & $\begin{array}{l}0.175^{\star \star \star} \\
(0.037)\end{array}$ \\
\hline
\end{tabular}

Notes: ${ }^{\star \star \star},{ }^{\star \star},{ }^{\star}$ denote statistical significance on the $1 \%, 5 \%$, and $10 \%$ level, respectively. Robust standard errors (clustered by country pairs) are given in parentheses. Controls: geographic distance, dummies for free trade agreement, currency union, common border, common legal system, common language, colonial ties, dummy variable allowing for a different intercept for NN, SS, NS and SN trade flows $\left(\tau_{n c}\right)$, importer and exporter fixed effects $\left(A_{c}\right.$ and $\left.A_{n}\right)$. Sample: countries with population $>$ 1 million, HS6 codes which include consumer goods. This table reports the estimation results from equation [13), estimated for each year separately. The dependent variables are defined in equation 12 . The income similarity measures are defined in equations (4)- 6 . 


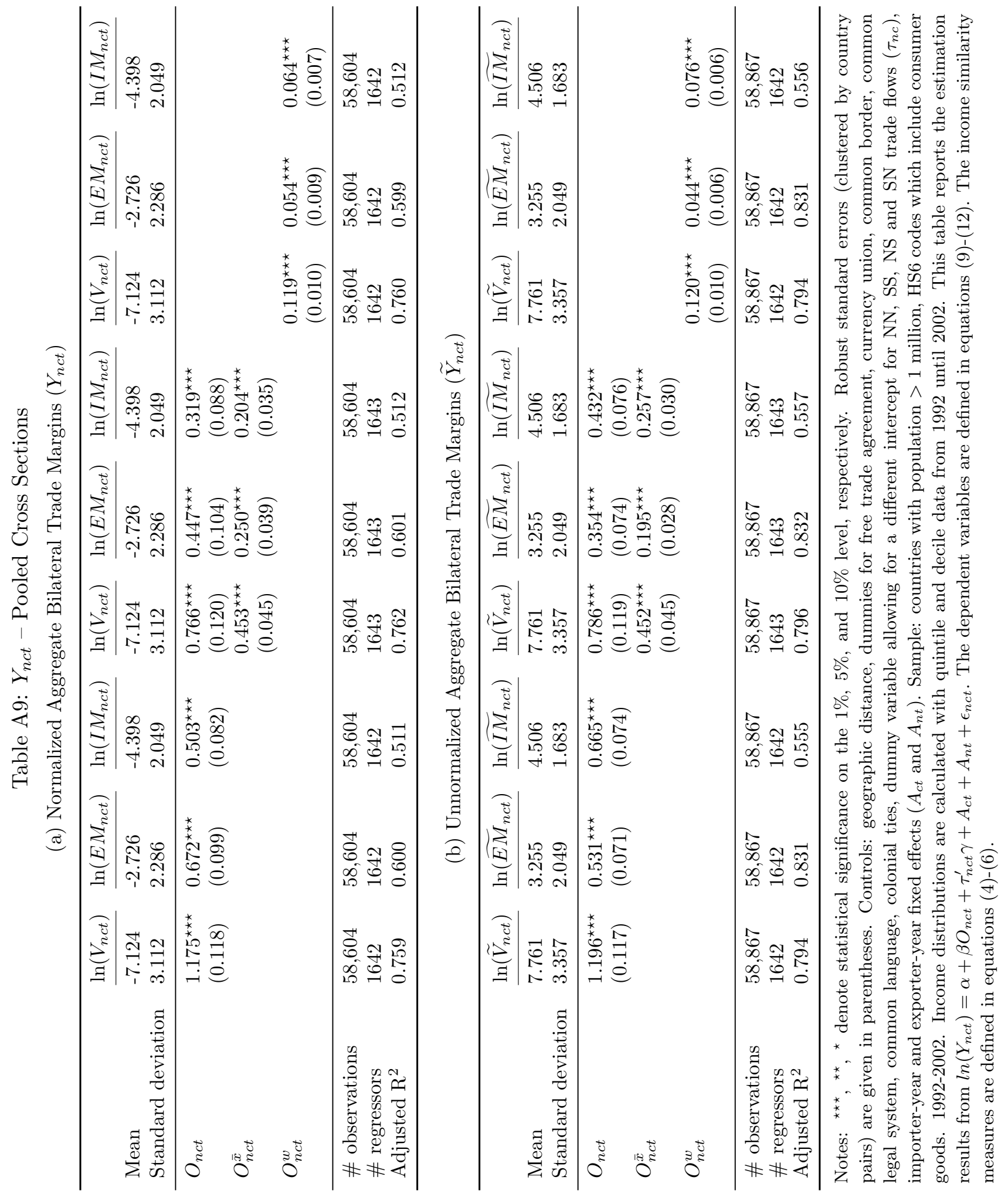


Table A10: $\hat{\beta}_{i}$ - Estimating Equation 17 for each HS4 Product Category separately

\begin{tabular}{llllllll}
\hline & $\min$ & $25^{\text {th }}$ perc. & median & mean & $75^{\text {th }}$ perc. & $\max$ & $\mathrm{N}$ \\
\hline HS4 codes, except apparel & -2.94 & -0.26 & 0.28 & 0.27 & 0.90 & 2.86 & 279 \\
HS4 codes, apparel & -2.10 & -1.01 & -0.71 & -0.79 & -0.57 & 0.14 & 34 \\
all HS4 codes & -2.94 & -0.51 & 0.14 & 0.16 & 0.79 & 2.86 & 313 \\
\hline
\end{tabular}

Notes: This table reports summary statistics of the distribution of $\hat{\beta}_{i}$. $\hat{\beta}_{i}$ is obtained by estimating equation 17 separately for each HS4 code $i$, i.e. estimating $\ln \left(I M_{n c i}\right)=\alpha_{i}+\beta_{i} O_{n c}+\tau_{n c}^{\prime} \gamma_{i}+A_{c i}+A_{n i}+\epsilon_{n c i}$ for each $i$ separately.

Table A11: $Y_{n c i}$ - Apparel versus Non-Apparel Categories

\begin{tabular}{|c|c|c|c|c|c|c|}
\hline \multirow{5}{*}{$\begin{array}{l}\text { Mean } \\
\text { Standard deviation }\end{array}$} & \multicolumn{3}{|c|}{ HS6 codes containing apparel } & \multicolumn{3}{|c|}{ HS6 codes not containing apparel } \\
\hline & \multirow{4}{*}{$\begin{array}{l}\frac{E M_{n c i}}{0.092} \\
0.290\end{array}$} & \multicolumn{2}{|c|}{$\ln \left(I M_{n c i}\right)$} & $E M_{n c i}$ & \multicolumn{2}{|c|}{$\ln \left(I M_{n c i}\right)$} \\
\hline & & \multicolumn{2}{|c|}{3.668} & 0.076 & \multicolumn{2}{|c|}{3.889} \\
\hline & & \multicolumn{2}{|c|}{2.115} & 0.265 & \multicolumn{2}{|c|}{2.204} \\
\hline & & OLS & Cosslett & & OLS & Cosslett \\
\hline$O_{n c}$ & $0.132^{\star \star \star}$ & $-0.827^{\star \star \star}$ & $-0.558^{\star \star \star}$ & $0.115^{\star \star \star}$ & $0.202^{\star \star}$ & $0.580^{\star \star \star}$ \\
\hline & {$[0.135]$} & {$[-0.104]$} & {$[-0.070]$} & {$[0.128]$} & {$[0.025]$} & {$[0.071]$} \\
\hline & $(0.009)$ & $(0.143)$ & $(0.156)$ & $(0.006)$ & $(0.083)$ & $(0.100)$ \\
\hline Selection? & & No & Yes & & No & Yes \\
\hline \# observations & $2,400,366$ & 221,701 & 221,701 & $10,590,456$ & 806,449 & 806,449 \\
\hline \# regressors & 450 & 450 & 550 & 1245 & 1244 & 1344 \\
\hline Adjusted $\mathrm{R}^{2}$ & 0.371 & 0.410 & 0.427 & 0.304 & 0.292 & 0.323 \\
\hline
\end{tabular}

Notes: ${ }^{\star \star \star},{ }^{\star \star},{ }^{\star}$ denote statistical significance on the $1 \%, 5 \%$, and $10 \%$ level, respectively. Robust standard errors (clustered by country pairs) are given in round brackets. Standardized beta coefficients are given in square brackets. Controls: geographic distance, dummies for free trade agreement, currency union, common border, common legal system, common language, colonial ties, dummy variable allowing for a different intercept for $\mathrm{NN}, \mathrm{SS}, \mathrm{NS}$ and $\mathrm{SN}$ trade flows $\left(\tau_{n c}\right)$, importer, exporter and HS6 code fixed effects $\left(A_{c}\right.$, $A_{n}$ and $A_{i}$ ). Sample: countries with population $>1$ million, HS6 codes which include consumer goods. Year $=2002$. Income distributions are calculated with quintile and decile data from 1992 until 2002. This table reports the estimation results from equation $[16, \sqrt{17}$ and $[18$, where $J=100$. The dependent variables are defined in equation (7) and (8). The income similarity measure $O_{n c}$ is defined in equation (4). A HS6 code belongs to apparel if its higher-ranking HS2 code is 61 (articles of apparel, accessories, knit or crochet) or 62 (articles of apparel, accessories, not knit or crocheted). 


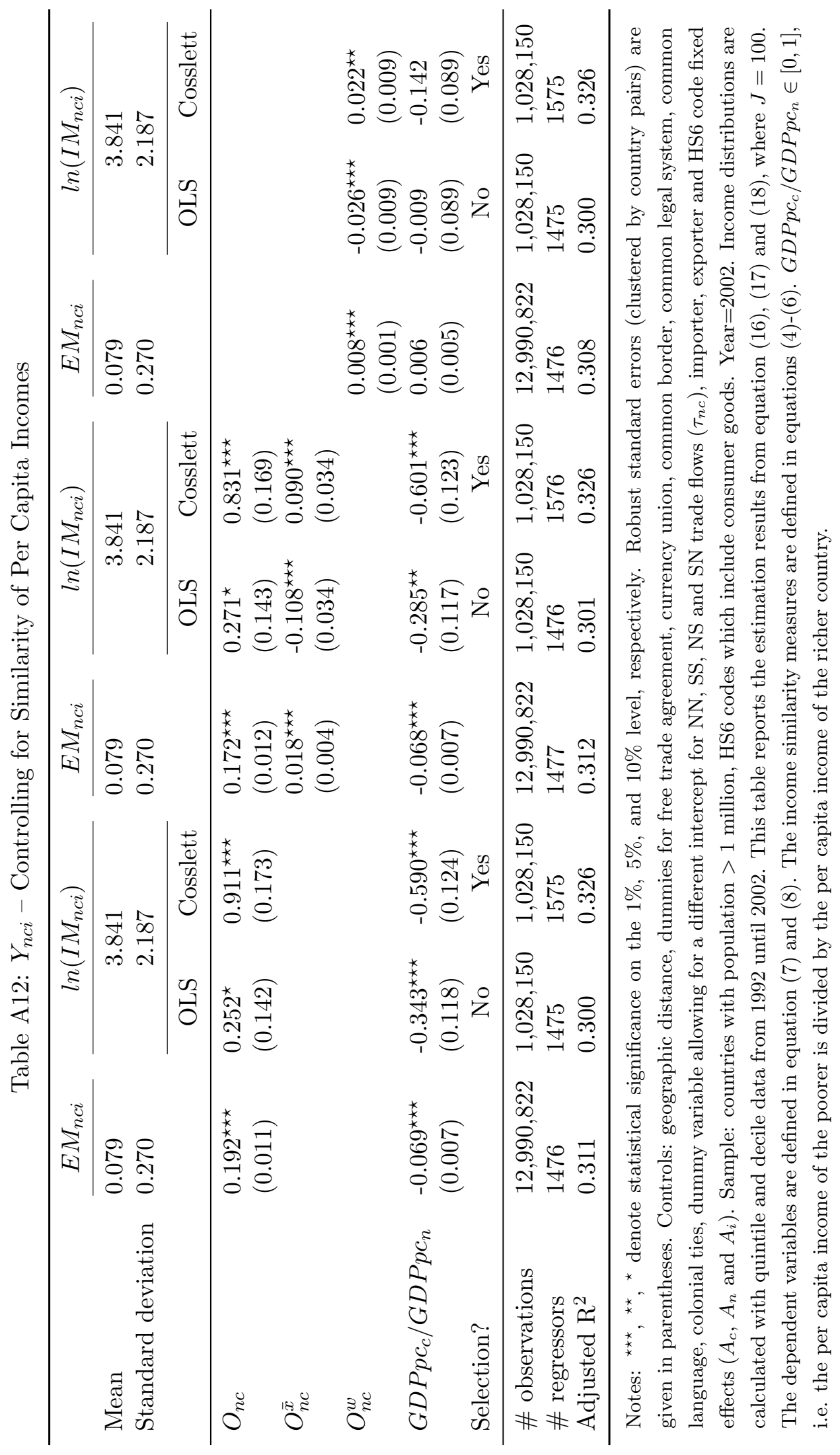


Table A13: $Y_{n c i}-$ All Years

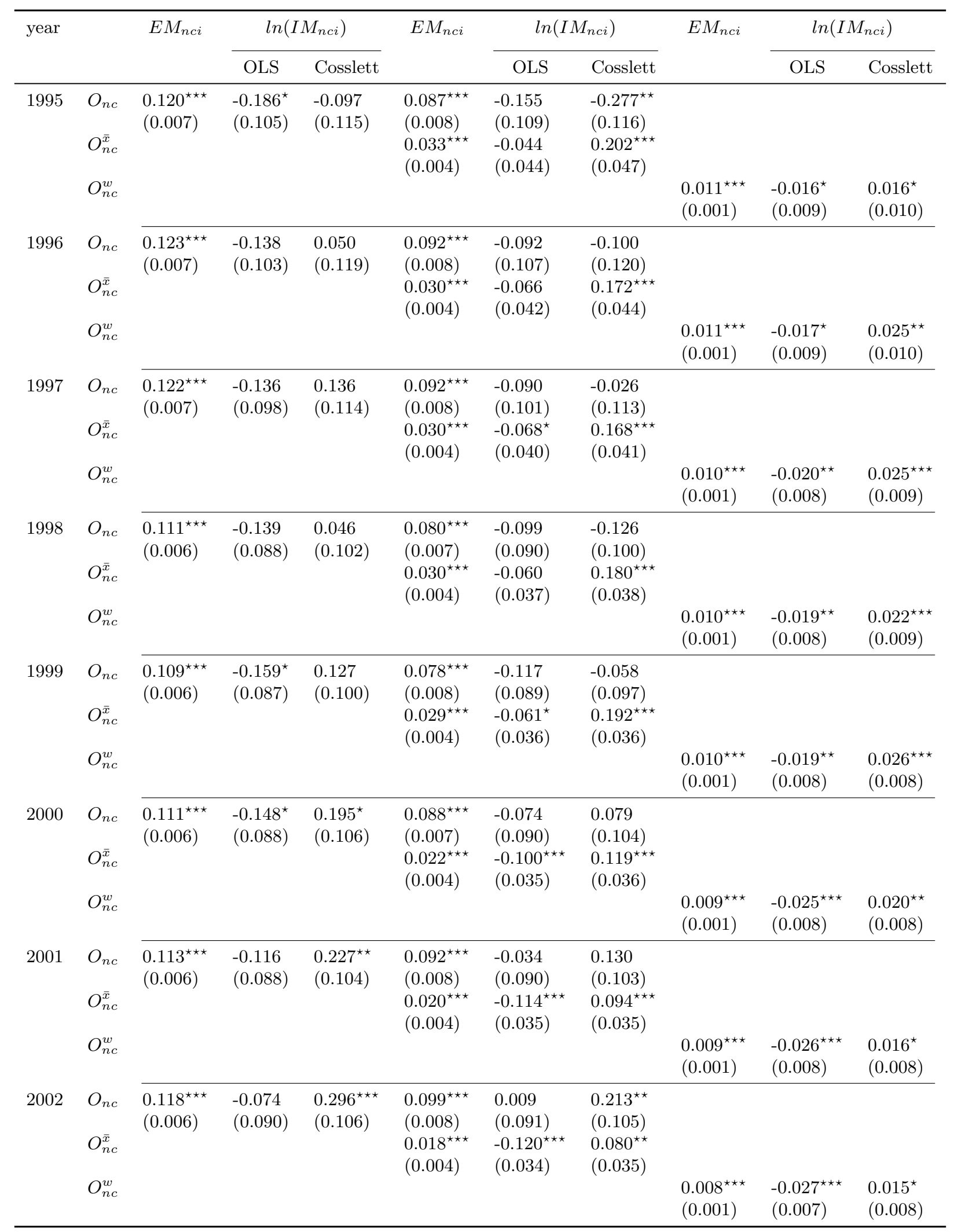

Notes: ${ }^{\star \star \star},{ }^{\star \star},{ }^{\star}$ denote statistical significance on the $1 \%, 5 \%$, and $10 \%$ level, respectively. Robust standard errors (clustered by country pairs) are given in parentheses. Controls: geographic distance, dummies for free trade agreement, currency union, common border, common legal system, common language, colonial ties, dummy variable allowing for a different intercept for NN, SS, NS and SN trade flows $\left(\tau_{n c}\right)$, importer, exporter and HS6 code fixed effects $\left(A_{c}, A_{n}\right.$ and $\left.A_{i}\right)$. Sample: countries with population $>1$ million, HS6 codes which include consumer goods. Income distributions are calculated with quintile and decile data from 1992 until 2002. This table reports the estimation results from equation (16), 17] and 18], where $J=100$, for each year between 1995 and 2002. The dependent variables are defined in equation (7) and (8). The income similarity measures are defined in equations (4)-6. 
Table A14: $Y_{n c i t}$ - Pooled Cross Sections for all Levels of Aggregation

\begin{tabular}{|c|c|c|c|c|c|c|c|c|c|c|}
\hline & & \multirow[t]{2}{*}{$E M_{n c i t}$} & \multicolumn{2}{|c|}{$\ln \left(I M_{n c i t}\right)$} & \multirow[t]{2}{*}{$E M_{n c i t}$} & \multicolumn{2}{|c|}{$\ln \left(I M_{n c i t}\right)$} & \multirow[t]{2}{*}{$E M_{n c i t}$} & \multicolumn{2}{|c|}{$\ln \left(I M_{n c i t}\right)$} \\
\hline & & & OLS & Cosslett & & OLS & Cosslett & & OLS & Cosslett \\
\hline \multirow[t]{3}{*}{ HS6 } & $O_{n c}$ & $\begin{array}{l}0.116^{\star \star \star} \\
(0.006)\end{array}$ & $\begin{array}{l}-0.141 \\
(0.088)\end{array}$ & $\begin{array}{l}0.127 \\
(0.103)\end{array}$ & $\begin{array}{l}0.089^{\star \star \star} \\
(0.008)\end{array}$ & $\begin{array}{l}-0.082 \\
(0.090)\end{array}$ & $\begin{array}{l}-0.014 \\
(0.101)\end{array}$ & & & \\
\hline & $O_{n c}^{\bar{x}}$ & & & & $\begin{array}{l}0.025^{\star \star \star} \\
(0.004)\end{array}$ & $\begin{array}{l}-0.084^{\star \star} \\
(0.035)\end{array}$ & $\begin{array}{l}0.147^{\star \star \star} \\
(0.036)\end{array}$ & & & \\
\hline & $O_{n c}^{w}$ & & & & & & & $\begin{array}{l}0.010^{\star \star \star} \\
(0.001)\end{array}$ & $\begin{array}{l}-0.022^{\star \star \star} \\
(0.007)\end{array}$ & $\begin{array}{l}0.019^{\star \star} \\
(0.008)\end{array}$ \\
\hline \multirow[t]{3}{*}{ HS4 } & $O_{n c}$ & $\begin{array}{l}0.167^{\star \star \star} \\
(0.008)\end{array}$ & $\begin{array}{l}0.132 \\
(0.090)\end{array}$ & $\begin{array}{l}0.335^{\star \star \star} \\
(0.112)\end{array}$ & $\begin{array}{l}0.116^{\star \star \star} \\
(0.009)\end{array}$ & $\begin{array}{l}0.171^{\star} \\
(0.093)\end{array}$ & $\begin{array}{l}0.146 \\
(0.107)\end{array}$ & & & \\
\hline & $O_{n c}^{\bar{x}}$ & & & & $\begin{array}{l}0.049^{\star \star \star} \\
(0.005)\end{array}$ & $\begin{array}{l}-0.050 \\
(0.036)\end{array}$ & $\begin{array}{l}0.221^{\star \star \star} \\
(0.039)\end{array}$ & & & \\
\hline & $O_{n c}^{w}$ & & & & & & & $\begin{array}{l}0.015^{\star \star \star} \\
(0.001)\end{array}$ & $\begin{array}{c}-0.004 \\
(0.008)\end{array}$ & $\begin{array}{l}0.034^{\star \star \star} \\
(0.009)\end{array}$ \\
\hline \multirow[t]{3}{*}{ HS2 } & $O_{n c}$ & $\begin{array}{l}0.206^{\star \star \star} \\
(0.009)\end{array}$ & $\begin{array}{l}0.452^{\star \star \star} \\
(0.086)\end{array}$ & $\begin{array}{l}0.487^{\star \star \star} \\
(0.116)\end{array}$ & $\begin{array}{l}0.134^{\star \star \star} \\
(0.010)\end{array}$ & $\begin{array}{l}0.357^{\star \star \star} \\
(0.089)\end{array}$ & $\begin{array}{l}0.301^{\star \star \star} \\
(0.107)\end{array}$ & & & \\
\hline & $O_{n c}^{\bar{x}}$ & & & & $\begin{array}{l}0.070^{\star \star \star} \\
(0.004)\end{array}$ & $\begin{array}{l}0.113^{\star \star \star} \\
(0.034)\end{array}$ & $\begin{array}{l}0.228^{\star \star \star} \\
(0.042)\end{array}$ & & & \\
\hline & $O_{n c}^{w}$ & & & & & & & $\begin{array}{l}0.019^{\star \star \star} \\
(0.001)\end{array}$ & $\begin{array}{l}0.035^{\star \star \star} \\
(0.008)\end{array}$ & $\begin{array}{l}0.041^{\star \star \star} \\
(0.010)\end{array}$ \\
\hline \multirow[t]{3}{*}{ HS1 } & $O_{n c}$ & $\begin{array}{l}0.224^{\star \star \star} \\
(0.011)\end{array}$ & $\begin{array}{l}0.672^{\star \star \star} \\
(0.091)\end{array}$ & $\begin{array}{l}0.210^{\star} \\
(0.115)\end{array}$ & $\begin{array}{l}0.150^{\star \star \star} \\
(0.012)\end{array}$ & $\begin{array}{l}0.456^{\star \star \star} \\
(0.093)\end{array}$ & $\begin{array}{l}0.201^{\star} \\
(0.104)\end{array}$ & & & \\
\hline & $O_{n c}^{\bar{x}}$ & & & & $\begin{array}{l}0.071^{\star \star \star} \\
(0.005)\end{array}$ & $\begin{array}{l}0.249^{\star \star \star} \\
(0.036)\end{array}$ & $\begin{array}{l}0.018 \\
(0.042)\end{array}$ & & & \\
\hline & $O_{n c}^{w}$ & & & & & & & $\begin{array}{l}0.020^{\star \star \star} \\
(0.001)\end{array}$ & $\begin{array}{l}0.067^{\star \star \star} \\
(0.008)\end{array}$ & $\begin{array}{l}0.007 \\
(0.010)\end{array}$ \\
\hline
\end{tabular}

Notes: ${ }^{\star \star \star},{ }^{\star \star},{ }^{\star}$ denote statistical significance on the $1 \%, 5 \%$, and $10 \%$ level, respectively. Robust standard errors (clustered by country pairs) are given in parentheses. Controls: geographic distance, dummies for free trade agreement, currency union, common border, common legal system, common language, colonial ties, dummy variable allowing for a different intercept for NN, SS, NS and SN trade flows $\left(\tau_{n c}\right)$, importer-year, exporter-year and HS code fixed effects $\left(A_{c t}, A_{n t}\right.$ and $\left.A_{i}\right)$. Sample: countries with population $>1$ million, HS codes which include consumer goods. 1995-2002. Income distributions are calculated with quintile and decile data from 1992 until 2002. This table reports the estimation results from equation [16, (17) and 18, where $J=100$. The dependent variables are defined in equation (7) and 8). The income similarity measures are defined in equations $40-(6)$. 